\title{
EFEITOS DE ÉPOCAS DE SEMEADURA, ESPACAMENTOS E MOMENTOS DE CORTE SOBRE O DESENVOLVIMENTO, PRODUÇÃO DE MASSA VERDE, MATÉRIA SECA E SEMENTES DE TREMOÇO (Lupinus albus L.)
}

\section{ANTONIO CARLOS BENASSI \\ Engenheiro Agrônomo}

Orientador: Prof. Dr. JAIRO TEIXEIRA MENDES ABRAHĀO

Dissertação apresentada à Escola Superior de Agricultura "Luiz de Queiroz", da Universidade de São Paulo, para obtenção do título de Mestre em Agronomia - Area de concentração: Fitotecnia.

PIRACICABA

Estado de São Paulo - Brasil

Agosto de 1988 
Benassi, Antonio Carlos

B456e Efeitos de épocas de semeadura, espaçamentos e monentos de corte sobre o desenvolvimento, produção de massa verde, matéria seca e sementes de tremoço (Lupinus àlbus L.). piracicaba", 1988.

$115 p$.

Diss.(Mestre) - ESALQ

Bibliografia.

1. Tremoço - Corte 2. Tremoço - Crescimento 3. Tremoço Época de semeadura 4. Tremoço - Espaçamento 5. Tremoço - Pro dução I. Escola Superior de Agricultura Luiz de Queiroz, Pira cicaba

$\operatorname{CDD} \quad 633.367$ 
EFEITOS DE EPOCAS DE SEMEADURA, ESPAÇAMENTOS E MOMENTOS DE CORTE SOBRE O DESENVOLVIMENTO, PRODUÇ̊O DE MASSA VERDE, MATERIA SECA E SEMENTES DE TREMOÇO (Lupinus albus L.)

ANTONIO CARLOS BENASSI

Aprovada em: $30: 09.1988$

Comissão Julgadora:

Prof. Dr. Jairo Teixeira Mendes Abrahão

ESALQ/USP

Prof. Dr. José Dias Costa

ESALQ/USP

Prof. Dr. Luiz Antonio Rochelle

ESALQ/USP

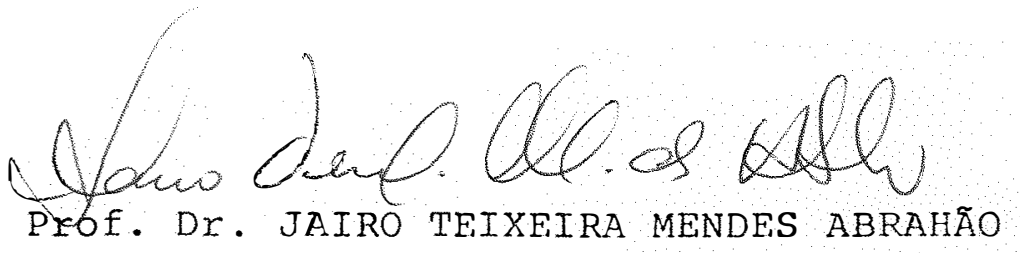

- Orientador - 
. ii.
A minha mãe Maria
e irmã Shirlen,
MINHA GRATIDAO

\begin{abstract}
A minha esposa Vera pelo Amor
e incentivo sempre dispensados,

DEDICO
\end{abstract}

A meus filhos

Everton, Vivian e Anderson,

OFEREÇO 


\section{AGRADECIMENTOS}

- Ascola Superior de Agricultura "Luiz de Queiroz", Universidade de são Paulo, pela oportunidade oferecida.

- Ao Professor Dr. Jairo Teixeira Mendes Abrahão, Prof. Adjunto do Departamento de Agricultura da ESALQ, pela orientação, apoio e amizade.

- Aos Professores Drs. José Dias Costa e Oswaldo Pereira Godoy, assim como os demais professores do curso de pós-graduação, pelos conhecimentos recebidos.

- Ao Professor Dr. Décio Barbin, pela elaboração do delineamento experimental utilizado.

- Ao Professor Dr. Evôneo Berti Filho, pela versao do resumo para o inglès.

- Ao Conselho Nacional de Desenvolvimento Cientifico e Tecnológico, CNPq, pelo auxilio financeiro concedido.

- A Usina Açúcar e Álcool Bandeirantes, na pessoa do Sr. Serafjm Meneghel, pelo combustivel cedido para as viagens.

- Aos acadêmicos, Luiz, Maurino, Francisco e Carlos, pela colaboração na instalação e condução do experimento.

- Ao colega Nilton Dessaune Filho, pelo auxílio nas análises estatisticas.

- A minha esposa Vera Lúcia Rodrigues Machado Benassi, pelo constante apoio. 
. iv .

- A todos que direta ou indiretamente contribuiram para O êxito deste trabalho. 


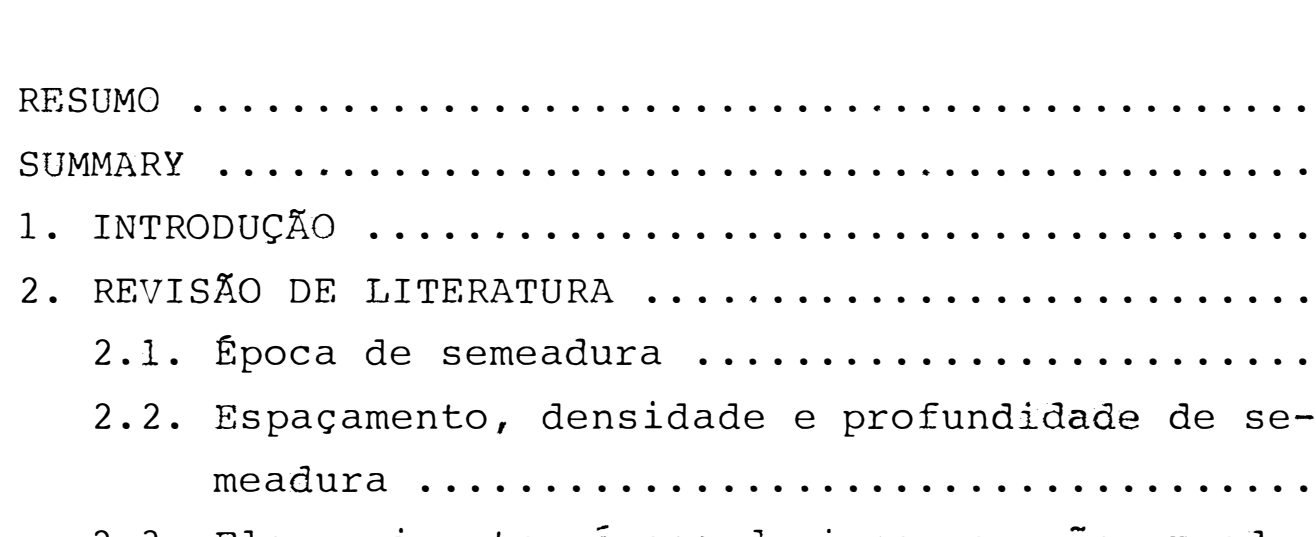
página

viii

$\mathrm{x}$

2.3. Florescimento, época de incorporação, produção de massa verde e matéria seca .........



1

4

4

10

18

25

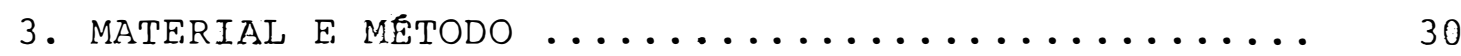

3.1 . Local 30





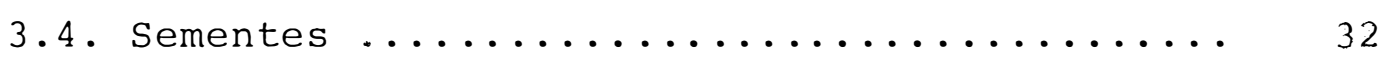

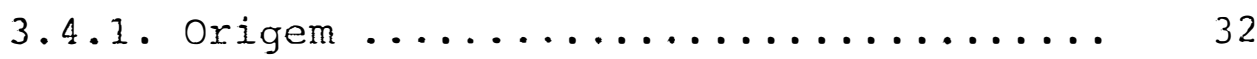

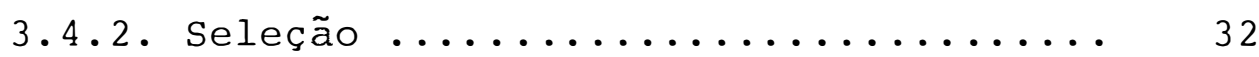

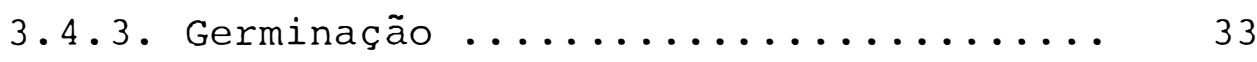

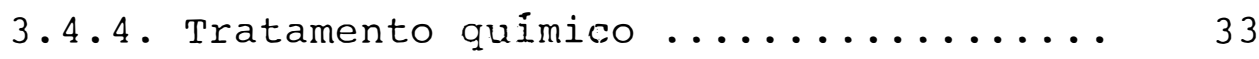

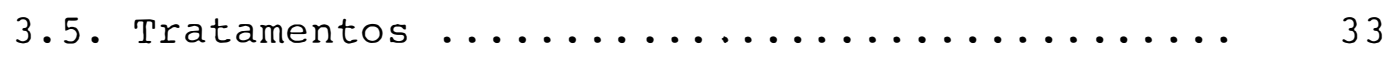

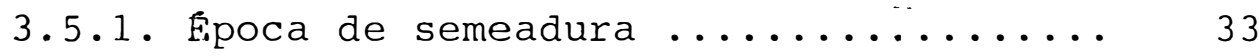



3.5.3. Epoca de corte ............... 34

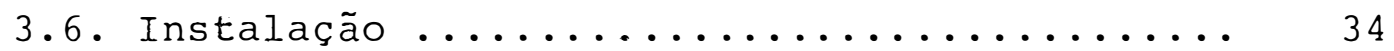

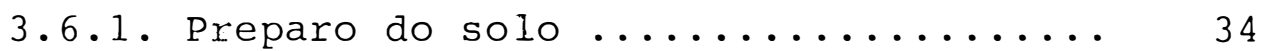

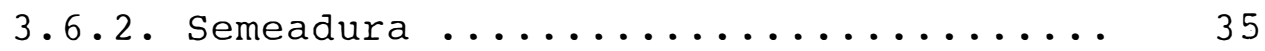

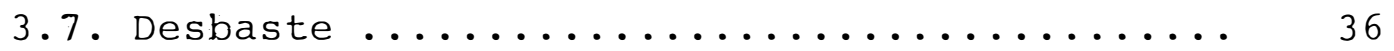

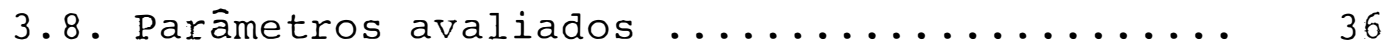



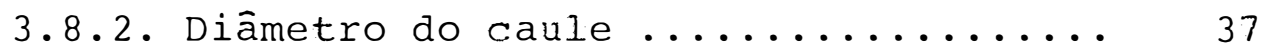

3.8.3. Produção de massa verde .......... 37

3.8.4. Produção de matéría seca .......... 38 


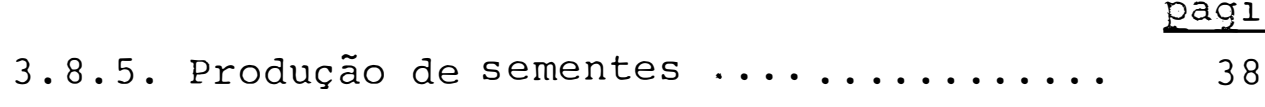

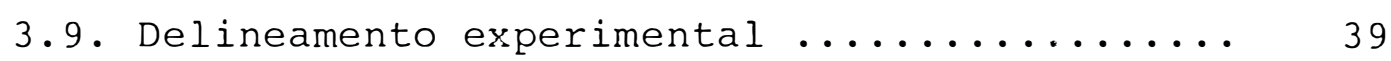



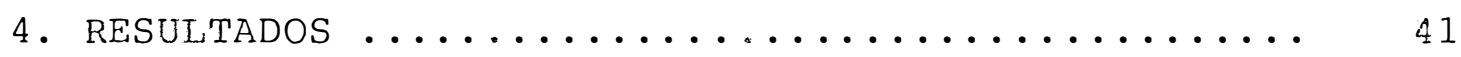

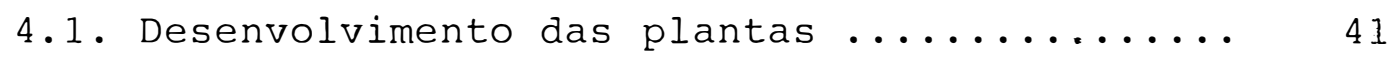

4.1.1. Altura de plantas até a gema apical ou base da inflorescência principal. 41

4.1.2. Altura total de plantas ......... 46

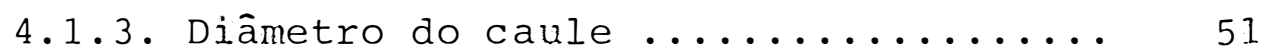

4.2. População de plantas na avaliação do rendimento de massa verde e matéria seca ....... 56

4.3. Produção de massa verde ................ 60

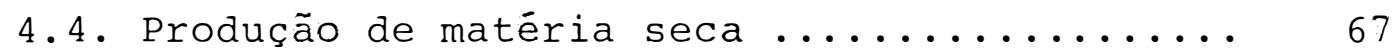

4.5. Populações de plantas na ocasião da colheita de sementes $\quad 72$

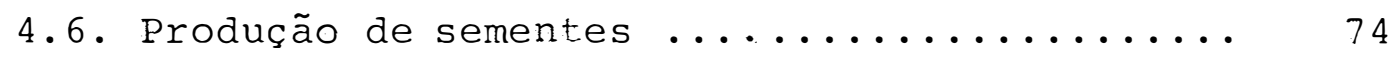

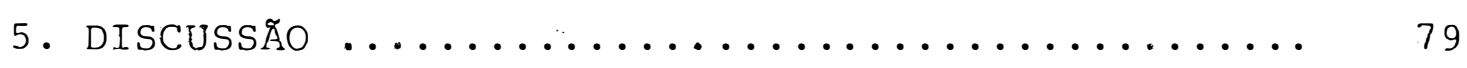

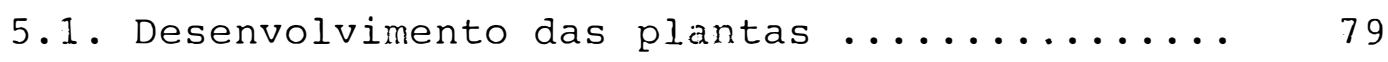

5.1.1. Altura de plantas até a gema apical ou base da inflorescēncia principal . 79





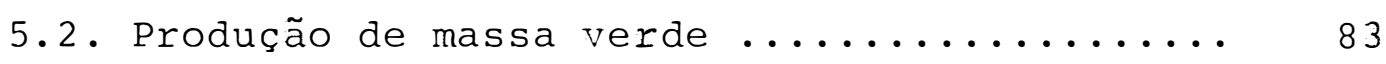



5.2.2. Espaçamento entre Iinhas ......... 86

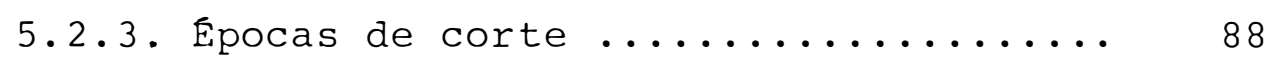

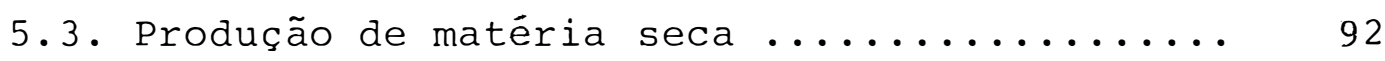

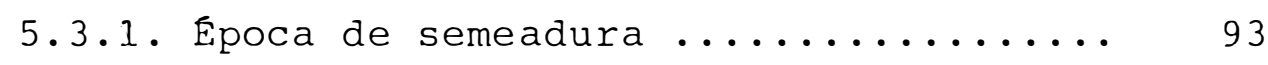

5.3.2. Espaçamentos entre linhas ......... 94

5.3.3. Epoca de corte ................ 94

5.4. Produção de sementes ...... 96

5.4.1. Épocas de semeadura 96 
.vii.

página

5.4.2. Espaçamento entre linhas ......... 98

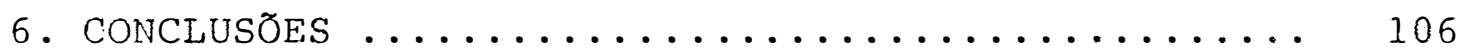

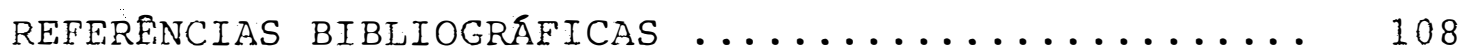


EFEITOS DE F.POCAS DE SEMEADURA, ESPAÇAMENTOS E MOMENTOS DE CORTE SOBRE O DESENVOLVIMENTO, PRODUÇÃO DE MASSA VERDE, MATÉ.RIA SECA E SEMENTES DE TREMOÇO (Lupinus albus L.)

Autor: ANTONIO CARLOS BENASSI

Orientador: Prof. Dr. JAIRO T.M. ABRAHÃO

RF.SUMO

Com a finalidade de melhor conhecer o comportamento do tremoço (Lupinus albus L.) em função de épocas de semeadura e de espaçamentos entre linhas, instalou-se, no ano de 1985, ensaio no municipio de Bandeirantes, PR. O delineamento experimental foi em blocos casualizados com parcelas subdivididas em esquema fatorial. Os tratamentos utilizados foram: 4 épocas de semeadura $(23$ de março, 15 de abril, 18 de maio e 15 de junho); 4 espaçamentos $(0,20,0,30,0,40$ e $0,50 \mathrm{~m})$ e 4 épocas de corte $(60,75,90$ e 105 dias apos emergēncia), com 3 repetições. Os parâmetros estudados foram: altura de" planta e diâmetro de caule, com avaliações aos $15,30,45,60,75,90,105$ e 120 dias após a emergência; massa verde e matéria seca, avaliadas aos $60,75,90$ e 105 dias após a emergência, e produção de sementes. A análise e a discussão dos dados permitem concluir que: a. a altura das plantas é maior para semeadura em março-abril e para espaçamentos de 0,20 - 0,30 m entre linhas; b. o diâmetro dos caules é aumentado pelas semeaduras em março-abril e pelos espaçamentos maiores; c. as produções de massa verde e matéria seca aumentam com a antecipação de semeadura e com a diminuição do espaçamento entre linhas; d. para plantios antecipados é recomendável a realização do corte das plantas aos 
100 dias após a emergência; e. para semeaduras retardadas e condições menos favoráveis recomenda-se o corte das plantas aos 80 dias após a emergéncia, $f$. a produção de sementes aumenta com a antecipação da semeadura e com a diminuição do espaçamento entre Iinhas. 
EFFECTS OF SOWING DATE, SPACING AND TIME OF CUTTING ON THE DEVELOPMENT AND YIELD OF FRFSH MATTER, DRY MATTER AND SEEDS LUPIN (Lupinus albus L.)

\author{
Author: ANTONIO CARLOS BENASSI
}

Adviser: Prof. Dr. JAIRO T.M. ABRAHAO

\title{
SUMMARY
}

This research deals with the development of lupin (Lupinus albus L.) according to the sowing dates and spacing between rows. The experiment was set in Bandeirantes, State of Parana, Brazil. The factorial experiment was a split plot randomised block design. The treatments were: 4 sowing dates (March 23, April 15, May 18, and June 15), 4 spacings $(0.20 ; 0.30 ; 0.40 ; 0.50 \mathrm{~m})$ and 4 periods of cutting $(60,75,90$, and 105 days after emergence), with 3

replications. The parameters studied were: plant height and stem diametex, evaluated at $15,30,45,60,75,90$, and 105 days after emergence; fresh and dry matter evaluated at 60 , $75,90,105$ and 120 days after emergence; and seed yield. The results were as follows: a. plants are higher when seeds are sowed in March-April with spacings of $0.20-0.30 \mathrm{~m}$ between rows; b. the stem diameter is greater when seeds are sowed in March-April with the greater spacings; c. fresh and dry matter yield increase with the antecipation of the sowing date and the decrease of the spacing between rows; $d$. when the sowing date is anticipated it is recommendable to cut the plants 100 days after emergence; e. for late sowing dates and less favourable climatic conditions it is recommendable to cut the plants 80 days after emergence; $f$. The seed yield increases with early sowing and with the decrease of the spacing between rows. 


\section{INTRODUÇAO}

A adubação verde no Brasil vem se constituindo nos últimos anos, em importante atividade agrícola, recomendá vel principalmente em locais onde o solo é explorado intensamente, sem que nele seja adotada uma tecnologia conservacionista adequada, provocando degradação e queda na produtividade.

Diferentes espécies vegetais podem ser empregadas para esse fim, porém, as plantas da familia das leguminosas são as mais difundidas e utilizadas.

O cultivo da leguminosa tremoço branco (Lupinus albus L.) $\operatorname{com} 2 \mathrm{n}=50$ cromossomos, precede ao tempo dos Impérios Grego e Romano e pode ter sido iniciado há 2000 anos A.C. no Egito, segundo referéncias feitas para a descober ta de sementes de Lupinus em tumbas egípcias da 12 a Dinastia (GLADSTONES, 1970). Entretanto, Hanelt citado por GIADSTONES (1976), estudou profundamente 0 assunto e afirmou que essa espécie não estava presente no Figito até cerca do inicio da Era Cristã. Segundo o mesmo autor, o primeiro cultivo de L. albus foi provavelmente realizado na peninsula Balcânica, onde seus ancestrais selvagens ainda existem.

Das diversas espécies que compõe o gênero lupinus, as mais difundidas no mundo, são aquelas conhecidas como originärias da "Bacia do Mediterrāneo", destacando-se 
Luppinus albus L., Lupinus angustifolius L. e Lupinus luteus L.

No Brasil, atualmente, estas trés espécies são as mais difundidas e as que melhor se adaptam às condições edafoclimáticas do sul do pais. Dentre elas, a mais conhecida e utilizada é a espécie L. albus.

Foi introduzida no Brasil em época incerta, porém GRANATO (1925) cita experiéncias conduzidas com tremoço no Instituto Agronömico de Campinas (IAC) . Também CORREA (1939) na década de trinta, desenvolveu trabalhos e cita a utilização do tremoço como adubo verde no Rio Grande do sul.

Os efeitos benéficos da prática da adubação verde sobre as propriedades quimicas, físicas e biológicas do solo, são evidentes, quer pela proteção que a cobertura vegetal viva oferece ao solo contra os agentes erosivos, quer pelas modificações provocadas com a incorporação e decomposição do material.

o enriquecimento do solo em nitrogènio é devido a capacidade que às bactérias especificas têm de fixar - nitrogēnio átmosférico, transformando-o em formas prontamente assimiláveis pela planta, onde cerca de $2 / 3$ do conceúdo do nitrogēnio dessas espécies provém desse processo.

Análise efetuada no Instituto Agronōmico do Paraná revelou que a incorporação de $30000 \mathrm{~kg} \mathrm{ha}^{-1}$ de massa verde de L. albus, adicionou ao solo mais de $120 \mathrm{~kg} \cdot \mathrm{ha}^{-1}$ de nitrogénio.

No Estado do Paraná, o cultivo de tremoço para adubação verde apresenta grandes possibilidades de suces- 
so pois não se verificam limitações de clima e solo para que essa leguminosa se desenvolva no periodo outono-inverno.

O atual sistema agricola paranaense mostra a facilidade da adoção dessa prática, uma vez que as chamadas culturas de verão não seriam deslocadas, e que somente uma pequena parte da área destinada às culturas anuais é cultivada no inverno, permancendo mais de $70 \%$, ou seja, perto de 5 milhões de hectares, em pousio (DERPSCH, 1985).

Evidencia-se ainda, que a infra estrutura, hoje existente nas propriedades agricolas da região Norte do Paraná, facilita muito a viabilização do cultivo do tremoço, uma vez que essa cultura permite a mecanização desde a semeadura até a colheita, utilizando-se os mesmos equipamentos empregados para as culturas aa soja, trigo e milho, comuns na região.

Visando um melhor conhecimento da planta, bem como do seu comportamento, sob diferentes condiçōes de cuItivo, realizou-se a presente pesquisa, quantificando-se a produção de massa verde, matéria seca e sementes em função de épocas de semeadura, espaçamentos e momentos de corte. 


\section{REVISÃO DE LITERATURA}

\subsection{Epoca de semeadura}

Segundo GRANATO (1925) para o Estado de São Paulo, a semeadura no mès de abril é a mais favorável para o desenvolvimento vegetativo do lupinus albus. A tentativa de semeadura em setembro foi considerada desfavorável, provocando acentuada redução no ciclo vegetativo, com pouco desenvolvimento da parte aérea.

Para as condiçëes do Rio Grande do Sul, CORREA (1939) recomendou o outono, de preferēncia de abril a maio, como a época apropriada para a semeadura do tremoço. Desta forma, ele atinge o florescimento na primavera, podendo ser enterrado mais cedo, permitindo que a massa vegetal entre em decomposição e seja aproveitada pela cultura seguinte. Segundo esse autor, o tremoço por ser um vegetal cosmopolita, desenvolve-se também em climas quentes, apresentando porém, o inconveniente de produzir pouca massa vegetal, devido ao ciclo vegetativo curto, apressado pelo calor. Fm experimentos no Instituto Borges de Medeiros-RS, com a semeadura na primavera, em setembro, observou um periodo de 44 dias até seu florescimento, afirmando, em seu trabalho, ser preferivel a semeadura no outono. 
Trabalho realizado por KIEHL (1949) em Piracicaba, São Paulo, recomenda que o preparo da terra e a semeadura de tremoço sejam realizados após a colheita das culturas das águas: março e abril. Aponta que o fator chuva ë importantíssimo, principalmente no início da vegetação, pois culturas instaladas em fins de abril de 1948, logo após pequena chuva, e sem outra até o florescimento, conseguiram frutificar, dando porém, baixa produção. Na mesma área, com semeadura em março de 1949 , com boa distribuição de chuvas, a cultura desenvolveu-se bem melhor que no ano anterior.

A época para a semeadura do tremoço branco doce, é variável dependendo da região e finalidade a que se destina. UFER (1956) indicou, para as condições do Rio Grande do sul, que a semeadura do tremoço seja executada entre o principio de abril e inicio de junho. Segundo esse autor, ë possivel usá-1o como planta forrageira de inverno, comocorte das plantas feito após o florescimento do ramo principal e no início da formação dos ramos laterais.

ANÔNIMO (1962) relatou que para as condições encontradas no sul do pais, o tremoço mais cultivado e adaptado é a espécie, L. albus bastante rústica e precoce, sendo sua semeadura realizada no outono, especialmente nos meses de março e abril.

De acordo com ANONIMO (1968) o tremoço é uma leguminosa indicada para o plantio de inverno, devendo ser efetuado, de preferēncia, no fim da estação chuvosa, quando ocorrem ainda algumas chuvas, especialmente no mês de março para o Estado de são paulo, visto que, daí em diante, geralmente a seca prevalece por vários meses e que o bom desenvolvimento vegetativo da cultura esta diretamente relacionado com a intensidade de chuvas. 
GLADSTONES (1969) na Austrália Ocidental, recomenda a semeadura do tremoço o mais cedo possivel, preferencialmente antes da metade de maio e certamente até inicio de junho. Comenta que experimentos para determinação de épocas de semeadura tēm demonstrado que a semeadura no seco é possivel e proporciona bons resultados, existindo, entretanto, algum risco porque as plāntulas podem morrer com uma longa estiagem. o rápido crescimento das plantas na época em que há ainda calor proporciona uma grande vantagem na competicão com as plantas daninhas.

Conforme recomendação feita por LEAL

para as condições do Rio Grande do Sul, é preferivel a semeadura de outono, especificamente nos meses de abril e maio para a cultura do tremoço destinada a adubação verde. Entretanto, a semeadura poderá ser realizada em junho ou julho se a finalidade do cultivo for para a produça de grãos.

De acordo com BAER (1973), em estudo realizado no Brasil para verificar a possibilidade de produção e utilização de tremoço, a semeadura deve ser efetuada de abril a maio e a colheita de sementes de setembro a outubro, sendo a espécie L. allbus mais adequada para a produção de grãos.

Na Austrälia, FARRINGTON (1974) realizou experimento com L. luteus e L. angustifolius L. com a semeadura efetuada em diferentes épocas, sendo: 19.03, 16.04, 14.05 e 11.06.1969, mantendo o espaçamento fixo de $0,20 \mathrm{~m}$ entre $11-$ nhas e $0,20 \mathrm{~m}$ entre plantas. Observou que a produção de matéria seca foi maior quando essas espécies de tremoço foram semeadas nos meses de marco e abril.

RAHMAN \& GLADSTONES (1974) avaliaram, na Austrália, os efeitos do fotoperiodo natural e de 24 horas de 
luz, temperatura e/ou insolação sobre o florescimento e componentes da produção de 24 genótipos de 5 espécies de tremoço, cujas semeaduras foram efetuadas em 02.04, 17.05 e 01.07. observaram que o efeito da época de semeadura sob condições de 24 horas de fotoperiodo não foi significativo para os genótipos estudados com relação ao número de flores, número de sementes por vagem, peso de sementes e produtividade. Entretanto, a interação genótipo e época de semeadura foi altamente significativa, exceto para número de sementes por vagem.

MASEFIELD (1976) introduziu na Inglaterra, diversas linhagens de L. mutabilis originárias da América do Sul. Em 1974 efetuou a semeadura em 24 de setembro para observar se as plantas sobreviveriam no inverno inglès, porém acabaram morrendo em janeiro e fevereiro. Concluiu que não foi viável o cultivo daquela espécie no inverno local. As semeaduras realizadas na primavera de 1975, em 17 de março e 16 de abril, mostraram-se perfeitamente viáveis; entretanto, os rendimentos proporcionados com a semeadura de março foram superiores aqueles obtidos com a semeadura de abril, para todas as linhagens testadas.

REEVES (1976) concluiu que altas produções de tremoço são obtidas em Victória, na Austrália, quando a semeadura é efetuada no inicio de abril. A semeadura efetuada o mais cedo possivel é muito importante para o tremoço que cresce rapidamente em condições de ambiente fresco, florescendo em julho e agosto, com desenvolvimento da cultura antes da ocorrência de altas temperaturas e estresse hidrico.

Os dados obtidos por DERPSCH et alii (1980) no Paraná, permitem concluir que efetuando-se a semeadura do tremoço em abril, com condições favoráveis de precipitação 
no periodo, o L. albus atinge a máxima cobertura do solo cerca de 20 dias antes que L. luteus, porém em condições mais secas o L. Iuteus é mais resistente. os autores afirmaram ser possivel a semeadura do tremoço no período de abril a ju Tho, dependendo do objetivo. Se para a produção de sementes é desejável que a semeadura seja feita o mais cedo possivel, se for para a proteção do solo a época de plantio dependerá do período de tempo disponível da área.

FLOSS (1980) relatou no Rio Grande do Sul, que - tremoço é cultivado durante a estação fria e que temperaturas médias de 10 a $14^{\circ} \mathrm{C}$ são muito favoráveis ao seu crescimento. A época de semeadura está condicionada ao objetivo final da cultura: se for para adubação verde é preferivel a semeadura em abril e maio; caso seja para produção de semen tes, o plantio poderá ser efetuado em junho e julho.

"As condições edafoclimáticas do Chile permitem o cultivo do L. albus em diferentes periodos", afirmou MORA (1980). Por possuir uma boa resistência ao frio, até $-6^{\circ} \mathrm{C}$, essa espécie cresce adequadamente no inverno, quando as precipitações no período de junho a setembro não excedam a $500 \mathrm{~mm}$, pois o L. albus não tolera excesso de umidade. o cultivo no outono é possivel na Nona Região Agrícola do Chile, tendo seu florescimento na segunda quinzena de setembro e maturação em janeiro e fevereiro, apresentando ótimo potencial produtivo. O cultivo da primavera é realizado na região sul do chile, com semeadura entre agosto e setembro, sendo que a produtividade de sementes pode variar substancialmente por condições de precipitação.

Segundo informou BAER (1982) a região sul do Chile, apresenta excelentes condições para o cultivo do tremoço, especialmente o L. albus, sendo que os melhores resul- 
tados foram obtidos com semeaduras mais cedo, durante os meses de abril e maio, proporcionando altos rendimentos, ao re dor de $3000 \mathrm{~kg} \cdot \mathrm{ha}^{-1}$ de sementes colhidas mecanicamente em $f \underline{e}$ vereiro.

SCHERER (1982) constatou que na região oeste do Estado de Santa Catarina, a semeadura da maioria das áreas cultivadas com tremoço, é feita de março a junho. observações em campo, permitiram ao autor concluir que as semeaduras de abril e maio proporcionaram um maior desenvolvimento vegetativo das plantas.

De acordo com WALTON (1982) a escolha do cultivar e do local de cultivo do tremoço é essencial para se estabelecer a época e a taxa de semeadura, visando a máxima produção de sementes. A semeadura do tremoço é importante que seja efetuada precocemente para escapar do período de es tresse hídrico durante o período de florescimento e formação de sementes. Na região norte de Perth, Austrália, experimentos mostraram que a data critica da semeadura, para se evitar um rápido declínio na produção, é 15 de maio, enquanto para a região sul de perth, essa data critica é estendida até 15 de junho. Constatou-se que para cada semana de atraso na semeadura, após a data critica, ocorreu, em média, que da de produção de sementes de 150 a $200 \mathrm{~kg} \cdot \mathrm{ha}^{-1}$.

As principais leguminosas, utilizadas para adubação verde, segundo IGUE et ali1 (1984), variam sua produção de biomassa, principalmente em função da época de semeadura, disponibilidade de água, práticas culturais, fertilidade do solo, pragas e doenças. para o L. albus, os autores ináicaram como época mais favorável, para o Estado do paraná, a semeadura no período de março a maio. 
Ensaios conduzidos por SANTOS et alil com tremoço no Estado do Rio Grande do sul, em 1982 e 1983 , utilizando cinco épocas para a semeadura, sendo $23.04,007$. $05,21.05,04.06$ e 18.06 , revelaram que em ambos os anos os ensaios foram totalmente prejudicados por pragas e doencas, não sendo possivel uma avaliação dos resultados que permitissem uma indicação segura da melhor época para a semeadura.

Na região oeste do Estado de Santa Catarina, a semeadura da maioria das áreas cultivadas com tremoço, segundo ANONIMO (1985), ocorre de março a junho. Observações de campo evidenciam que, as semeaduras de abril e maio proporcionam um maior desenvolvimento das plantas, com maior rendimento de matéria seca.

\subsection{Espacamento, densidade e profundidade de semeadura}

ANONIMO (1925) considerou o tremoço como planta de grande importáncia para a adubação verde, aconselhando que sua semeadura seja efetuada em linhas distanciadas de $0,60 \mathrm{~m}$, utilizando-se cerca de 100 litros de sementes por hectare.

De acordo com CORREA (1939) a semeadura do tremoço pode ser realizada de trés maneiras: em covas equidistantes de $0,50 \times 0,50 \mathrm{~m}$ com gasto médio de 40 a $60 \mathrm{~kg}$. $\mathrm{ha}^{-1}$ de sementes; a lanço com gasto de $150 \mathrm{a} 180 \mathrm{~kg} \cdot \mathrm{ha}^{-1}$; em Iinhas, o ma is aconselhável para a adubação verde, utilizando-se espacamento de $0,30 \mathrm{~m}$ entre linhas, com gasto de $100 \mathrm{a}$ $120 \mathrm{~kg} \cdot \mathrm{ha}^{-1}$ de sementes. Quanto à profundidade de semeadura, ensaios foram conduzidos em 4 tipos de solos nas profundidades de $1,2,3,4,5$ e $6 \mathrm{~cm}$, concluindo que as melhores 
profundidades situaram-se entre 3 e $\mathrm{cm}$.

Estudos realizados por KIEHL (1949) no campus da Escola Superior de Agricultura "Luiz de Queiroz" revelaram que o espaçamento utilizado de 0,60 a $0,80 \mathrm{~m}$ entre linhas de semeadura foi considerado exagerado. Com a finalidade de se obter uma perfeita cobertura do solo e um maior rendimento de massa verde, indicou o espaçamento de $0,30 \mathrm{~m}$ entre linhas e no máximo $0,50 \mathrm{~m}$, devendo-se depositar as sementes nos sulcos, no mínimo 3 , a cada $0,10 \mathrm{~m}$ de distāncia.

UFER (1956) recomendou para as condiçôes de clima e solo do Rio Grande do sul, que a semeadura do tremoco branco seja efetuada em fileiras distanciadas de 0,40 a $0,50 \mathrm{~m}$, devendo o espaço entre as sementes ser de $0,10 \mathrm{~m}$, com a profundidade de semeadura não superior a $3 \mathrm{~cm}$. o gasto médio de sementes previsto é de 70 a $80 \mathrm{~kg} \cdot \mathrm{ha}^{-1}$.

Para as condiçães existentes na região sul do País, ANONIMO (1962) recomendoi para o tremoço branco uma taxa de semeadura de 150 a $180 \mathrm{~kg} \cdot \mathrm{ha}^{-1}$ para a semeadura a lanço. Considerou para o plantio em covas no espaçamento equidistante de $0,50 \times 0,50 \mathrm{~m}$, um gasto de 65 a $85 \mathrm{~kg} \cdot \mathrm{ha}^{-1}$, considerando esta situação como a mais indicada para a finalidade de produção de sementes. Para a semeadura em linhas, no espaçamento de $0,30 \mathrm{~m}$, entre linhas, a taxa de semeadura de 100 a $120 \mathrm{~kg} \cdot \mathrm{ha}^{-1}$, sendo este sistema preferido para a adubação verde. Recomendou ainda, a profundidade de semeadura de 2 a $3 \mathrm{~cm}$.

Para a semeacura do tremoço ArónI IO recomendou para as condições do Estado de são Paulo, o espaçamento de $0,50 \mathrm{~m}$ entre fileiras e $0,10 \mathrm{~m}$ entre plantas, sendo necessários $180 \mathrm{~kg}_{\text {alq }}{ }^{-1}$ de sementes. Espaçamentos meno- 
res entre plantas, por exemplo $0,05 \mathrm{~m}$, exigem uma

grande quantidade de sementes, tornando-se anti econōmicos.

JEAL (1970) indicou para as condições edafoclimáticas do Rio Grande do Sul, que a semeadura do tremoço, seja efetuada no espaçamento de $0,80 \mathrm{~m}$ entre linhas, permitindo os tratos culturais no periodo juvenil das plantas, utilizando-se 20 sementes por metro linear, com gasto médio de $75 \mathrm{~kg} \cdot \mathrm{ha}^{-1}$. Para a adubação verde, recomendou espaçamento de $0,40 \mathrm{~m}$ entre Iinhas e densidade de 20 sementes por metro linear, com gasto médio de $150 \mathrm{~kg} \cdot \mathrm{ha}^{-1}$ de sementes.

Diversas linhagens de L. mutabilis, originárias da América do sul foram introduzidas na Inglaterra por MASEFIFLD (1976). Estudos sobre seu comportamento foram efetuados, utilizando-se espaçamentos de $0,45 \mathrm{~m}$ entre linhas e 0,15 m entre plantas, sendo que os tradicionalmente utilizados para tremoço eram $0,20 \mathrm{~m}$ entre linhas e $0,15 \mathrm{~m}$ entre plantas. Visualmente os espaçamentos de $0,45 \mathrm{~m}$ entre linhas e 0,15 m entre plantas foram julgados como melhores aqueles usualmente empregados, porém foi verificado não haver uma perfeita cobertura das entre linhas. Foi sugerido que futuros trabalhos experimentais fossem realizados utilizando-se o espaçamento de $0,30 \mathrm{~m}$ entre linhas e 0,15 m entre plantas.

Em Canterbury na Nova Zelāndia, HERBERT (1977) estudou a influência da densidade populacional e remoção de ramos laterais sobre a produção de grãos e vagens de L. albus cV. Ultra e L. angustifolius cV. Unicrop. As densidades estudadas foram 10,65 e 93 plantas.m ${ }^{-2}$ para o cv. Ultra e 10, 53 e 83 plantas. $\mathrm{m}^{-2}$ para o cv. Unicrop, ambos com semeadura em 23 de agosto de 1976 no espaçamento padrão de $0,15 \mathrm{~m}$ entre linhas. Observou-se que para cv. Unicrop o acréscimo na produtividade foi praticamente nulo em densidades supe- 
riores à 53 plantas. $\mathrm{m}^{-2}$, enquanto que para o cV. Ultra houve ganho de produtividade até a densidade de 93 plantas. ${ }^{-2}$. Em ambos os cultivares pode-se observar que o aumento da densidade populacional acarretou redução do número de vagens por planta e rendimento de grãos.

HERBERT (1977) realizou trabalho em Canterbury, Nova Zelándia, com L. albus cv. Ultra. A semeadura foi efetuada em 23 de setembro de 1973 no espaçamento de $0,15 \mathrm{~m}$ entre linhas, onde o desenvolvimento e a produtividade de grãos foram avaliados em seis diferentes densidades populacionais. As populações obtidas no momento da colheita foram: 16,$4 ; 16,5,22,1 ; 25,0 ; 33,5$ e 35,6 plantas. ${ }^{-2}$. Constatou que o aumento na população de plantas ocasionou aumento na produtividade de sementes, variando de $2000 \mathrm{~kg} \cdot \mathrm{ha}^{-1} \mathrm{com}$ 16 plantas. $\mathrm{m}^{-2}$ até $3150 \mathrm{~kg} \cdot \mathrm{ha}^{-1}$ com 35 plantas. $\mathrm{m}^{-2}$.

Na região Nordeste de Victória - Austrália REEVFS et alii (1977) estudaram o comportamento fenológico de cultivares de L. albus e L. angustifolius em diferentes épocas de semeadura. Para L. albus, em todas as épocas estudadas, efetuou-se a semeadura utilizando-se espaçamento de $0,21 \mathrm{~m}$ entre linhas com uma densidade populacional de 50 plantas.m $\mathrm{m}^{-2}$, com gasto de $170 \mathrm{~kg} \cdot \mathrm{ha}^{-1}$ de sementes.

LEES (1978) constatou que para o agricultor garantir um bom rendimento de biomassa de L. albus na Inglaterra, a semeadura deve ser realizada no espaçamento de 0,18 m entre linhas com uma densidade populacional de 60 plantas. $\mathrm{m}^{-2}$, com gasto aproximado de $130 \mathrm{~kg} \cdot \mathrm{ha}^{-1}$ de sementes.

De acordo com WALTON (1978) as condições de clima, solo e a definição da época de semeadura são importantes para se atingir altos rendimentos de sementes de tremoço 
na Austrália. Entretanto, a densidade populacional exerce grande influência sobre o rendimento, uma vez que altas densidades populacionais acarretam uma severa competicão individual de plantas por espaço, água luz e nutrientes, impedindo o máximo desenvolvimento de vagens. Experimentos conduzidos em condições favoráveis para o desenvolvimento do tremoco, mostram que uma densidade populacional de 20 a 40 plantas. $m^{-2}$ permite uma boa produção, sendo necessária uma taxa de semeadura de 42 a $84 \mathrm{~kg} \cdot \mathrm{ha}^{-1}$ de sementes. Sob condições menos favoráveis de água, solo, atraso na época de semeadura e invasoras, recomendou densidade populacional maior com no mínimo 45 plantas.m ${ }^{-2}$, com taxa de semeadura variando de 90 a $130 \mathrm{~kg} \cdot \mathrm{ha}^{-1}$ de sementes.

ALONSO (1980) informou que entre as diversas espécies de tremoço somente L. albus é cultivada na Espanha. Existem limitações locais de clima e solo, onde cada caso deve ser ajustado à escolha do cultivar. Segundo o ciclo e caracteristicas da planta, de forma geral, em algumas regiōes é possivel a semeadura no outono, quando as geadas de inverno não são tão fortes para causar danos a vegetação, ou semeadura a partir do inicio de março nas áreas mais frias. o espaçamento normalmente recomendado é de $0,50 \mathrm{~m}$ entre $\mathrm{Il}$ nhas e 0,10 a $0,15 \mathrm{~m}$ entre plantas, dependendo da natureza do solo, sendo que a profundidade de semeadura não deve ser superior a 2 ou $3 \mathrm{~cm}$.

DERPSCH et alii (1980) afirmaram não existir estudos que determinem a melhor quantidade de sementes e 0 espaçamento para o plantio de tremoço no Paraná. Em área experimental do Instituto Agronómico do Paraná, cultivaram L. albus à razão de $140 \mathrm{~kg} \cdot \mathrm{ha}^{-1}$ de sementes no espaçamento de $0,17 \mathrm{~m}$ entre linhas, com população de 63 plantas.m ${ }^{-2}$. Em outra área, utilizaram $70 \mathrm{~kg} \cdot \mathrm{ha}^{-1}$ de sementes, no espaçamento 
de $0,50 \mathrm{~m}$ entre linhas, obtendo população de 29 platnas. ${ }^{-2}$. Após resultados obtidos, sugeriram espaçamento de 0,30 a 0,35 m entre linhas como mais apropriado. A profundidade de semeadura considerada ideal foi entre 3 a $5 \mathrm{~cm}$.

FLOSS (1980) no Rio Grande do Sul, recomendou a semeadura do L. albus no espaçamento de $0,80 \mathrm{~m}$ entre 11 nhas e densidade de 20 sementes aptas por metro linear com gasto médio de $75 \mathrm{~kg} \cdot \mathrm{ha}^{-1}$ de sementes, quando a finalidade fosse produção de sementes. Para a produção de biomassa, visando efetuar adubação verde, o espaçamento entre linhas deveria ser de $0,40 \mathrm{~m}$ com 20 sementes aptas por metro de sulco, gastando-se em média $150 \mathrm{~kg} \cdot \mathrm{ha}^{-1}$ de sementes.

MCGIBBON \& WILLIAMS (1980) estudaram na Inglaterra o efeito da densidade populacional de L. albus sobre a produção de sementes e conteúdo de óleo, utilizando sub-tratamentos com e sem remoção dos ramos laterais. As densidades populacionais estudadas foram: 6, 25 e 100 plantas. $\mathrm{m}^{-2}$. O efeito da remocão das ramificações laterais foi a causa da significativa redução na produção de sementes e seu conteúdo em óleo, das vagens do racemo principal, exceto para a alta densidade populacional. Altas densidades populacionais causaram redução na produtividade de sementes por planta. Afirmaram que não foi possivel, pelos resultados obtidos, extrapolar o número ótimo de plantas por unidade de área para maximizar a produção de sementes, porém outro trabalho sugere que a densidade populacional ótima, para as con dições ao sul da Inglaterra, é de 75 plantas.m ${ }^{-2}$.

MUZILLI et alii (1980) citaram que o espaçamento para a semeadura do tremoço destinado a adubação verde, deve ser de 0,30 a $0,35 \mathrm{~m}$ entre fileiras com 8 a 10 sementes por metro linear. Para a produção de sementes, indica- 
ram espaçamento de 0,70 a 0,80 m entre filas com 8 a 10 sementes por metro linear, sendo que a maior distância entre filas favorece a penetração de ar e luz, beneficiando o desenvolvimento da planta com aumento do número de vagens e tamanho das vagens produzidas.

Resultados obtidos por BRADLEY (1982)

com dois cultivares de L. albus na Inglaterra, cultivados em diferentes densidades populacionais de: $25,50,75$ e 100 plantas. $\mathrm{m}^{-2}$, revelaram que 0 aumento da densidade populacional acarretou reducão do rendimento individual das plantas. Os dados mostraram melhor potencial de rendimento de grãos na população de 75 plantas. $\mathrm{m}^{-2}$.

Segundo CURY et alii (1982) ensaios conduzi dos na região de Ponta Grossa no paraná, revelaram que das três espécies estudadas, L. albus, L. Iuteus e L. angustifolius, a espécie mais produtiva, tanto em massa verde quanto em sementes, foi L. albus. Para essa espécie e para a produção de massa verde, os melhores espaçamentos foram 0,17 e $0,34 \mathrm{~m}$ entre linhas e densidade de 10 plantas por metro linear. Para a produção de sementes, em plantio precoce, reco mendaram 0,51 m entre linhas com 5 a 10 sementes por metro linear e, para plantio tardio, 0,51 m entre linhas com densi dade de 10 a 15 sementes por metro linear.

PLANCQUAERT (1982) estudou na França o comportamento de diferentes cultivares de tremoco branco na pro dução de sementes, comparando diferentes densidades populacionais, sendo: 50,70 e 90 plantas. $\mathrm{m}^{-2}$, em dois espaçamentos entre fileiras: de 0,20 e $0,40 \mathrm{~m}$. Não encontrou diferencas significativas entre tratamentos.

Ensaios conduzidos com tremoço na Estação Ex- 
perimental de chapecó em Santa Catarina por SCHERER revelaram uma boa cobertura do solo e produção de sementes quando se usou espaçamento de $0,50 \mathrm{~m}$ entre linhas com densidade média de 15 plantas por metro linear. Indicou, ainda, ser de 3 a $5 \mathrm{~cm}$ a profundidade de semeadura.

De acordo com TOMASINI et alii (1982) para as condições do Fstado do Rio Grande do sul, a quantidade de sementes e o número de plantas de tremoco por metro quadrado carecem de informações cientificas, porém é comum o uso de $120 \mathrm{~kg} \cdot \mathrm{ha}^{-1}$ de sementes para a semeadura, quando o cultivo se destina à produção de grãos, e $150 \mathrm{~kg} \cdot \mathrm{ha}^{-1}$ de semente quan do o cultivo se destina à produção de massa verde.

MIYASAKA et alii (1983) indicaram, para as condiçóes do Estado de são Paulo, que a semeadura do tremoço seja realizada no espacamento de $0,50 \mathrm{~m}$ entre linhas, colocando-se uma semente a cada $0,20 \mathrm{~m}$, com densidade de $36 \mathrm{gra}-$ mas de sementes para $10 \mathrm{~m}^{2}$ de área, equivalendo a $36 \mathrm{~kg} \mathrm{ha}^{-1}$.

Com a finalidade de se utilizar o tremoço para a produção de massa verde, no Estado do Rio Grande do Sul, SABADIN (1984), recomendou o espaçamento de $0,40 \mathrm{~m}$ entre $11-$ nhas e $0,05 \mathrm{~m}$ entre plantas, com gasto de 120 a $150 \mathrm{~kg} \cdot \mathrm{ha}^{-1}$ de sementes, sendo que a profundidade de semeadura não deve ser superior a $5 \mathrm{~cm}$.

SANTOS et alii (1984) no Rio Grande do sul, relataram que em 1981 conduziram ensaio com tremoço nos espaçamentos de $0,20,0,40$ e $0,60 \mathrm{~m}$ entre linhas, mantendo-se 10 plantas por metro linear, com gasto médio de $270,135 \mathrm{e}$ $90 \mathrm{~kg} \cdot \mathrm{ha}^{-1}$ de sementes, não se verificando diferença signifi cativa entre os rendimentos de sementes obtidos. Entretanto, - maior valor absoluto foi de $3864 \mathrm{~kg} \cdot \mathrm{ha}^{-1}$ cultivado no es- 
pacamento de 0,40 m entre Iinhas. Em 1982 e 1983 , conduziram experimentos com diferentes espacamentos entre linhas, sendo: $0,20,0,40$ e $0,60 \mathrm{~m}$ com três densidades populacionais, 10,15 e 20 sementes por metro linear, não sendo possível a sua conclusão, uma vez que, os ensaios foram totalmente prejudicados pela intensa ocorréncia de pragas e doenças.

Experimentos realizados no IAPAR - Paraná por DERPSCH \& CALEGARI (1985) mostraram os melhores resultados para a produção de massa verde, com semeadura nos meses de abril e maio e densidade populacional de 30 plantas. $\mathrm{m}^{-2}$, is to significa 6 sementes por metro linear num espaçamento de $0,34 \mathrm{~m}$ entre linhas ou 18 sementes por metro linear num espacamento de $0,51 \mathrm{~m}$, considerando-se as sementes com 808 de poder germinativo, equivalendo a aproximadamente $140 \mathrm{~kg}^{-\mathrm{ha}^{-1}}$ de sementes. Para a produção de sementes basta uma taxa de semeadura de $90 \mathrm{~kg} \cdot \mathrm{ha}^{-1}$ de sementes.

BRAGA \& BULISANI (1986) recomendaram para o cultivo do tremoço, L. albus no Estado de são paulo, a semeadura em março e abril no espaçamento de 0,50 a $0,70 \mathrm{~m}$ entre linhas com densidade de 12 a 15 sementes por metro $11-$ near, com gasto médio de 80 a $90 \mathrm{~kg}^{-\mathrm{ha}}{ }^{-1}$ de sementes.

2.3. Florescimento, época de incorporação, produção de massa verde e matéria seca

Referēncias foram feitas por ANONIMO

indicando que a incorporação do tremoço, l. albus, destinado a adubação verde, deve ser realizada no período da floração.

GRANATO (1925) relatou que os antigos Romanos enterravam as plantas de tremoço, destinadas à adubação ver- 
de, quando tivessem uma terca parte das flores. Entretanto, indicou como a melhor época para efetuar o enterrio quando as plantas precedessem um pouco à floração plena.

Devido ao florescimento irregular do tremoço branco, L. albus, CORREA (1939) indicou que o agricultor poderá enterrá-10 quando $2 / 3$ da lavoura estiver florida, uma vez que, para as condiçoes do Estado do Rio Grande do sul obsrevou-se que essa espécie pode passar por até quatro florescéncias. Apesar do momento do enterrio ser variável de acordo com o clima e solo, para aquelas condicōes o autor recomenda que essa operação seja executada entre 54 a 60 dias após semeadura. Experimentos realizados nas condicōes do Rio Grande do sul, constataram valores de $6380 \mathrm{~kg} \cdot \mathrm{ha}^{-1}$ de matéria orgânica, correspondente a valores de 35000 a 40000 $\mathrm{kg} \cdot \mathrm{ha}^{-1}$ de massa verde.

Plinio citado por CORREA (1939), faz distinção quanto à época de enterrio da massa verde em função do tipo de solo, sendo que, quando as plantas forem cultivadas em solos argilosos essa operação deve ser realizada durante - periodo da terceira florada, e, quando cultivada em solos arenosos durante a segunda florada. Entretanto, Varrão citado por CORREA (1939), recomendou que o enterrio do tremoco fosse executado antes da producão de vagens.

O L. albus possui um ciclo vegetativo bastante curto e pode ser enterrado, segundo KIEHL (1949) no perído de 70 a 90 dias após sua germinação. Entretanto, o melhor momento para essa operação é durante seu pleno florescimento, sendo que a melhor maneira de fazē-lo é passando uma ceifadora e depois a grade de discos. Em cultivo realizado no campo experimental da ESALQ em Piracicaba, são pau10, obteve-se a produção de $25200 \mathrm{~kg} \cdot \mathrm{ha}^{-1}$ de massa verde.Foi 
considerada uma produção menor àquela obtida por

CORREA

(1939) no Rio Grande do Sul, devido ao clima mais quente e ao espaçamento exagerado que foi utilizado.

Lemmermann citado por KIEHL (1949) em trabaThos realizados na Alemanha, classificou a produção de massa verde em pequena quando até $8000 \mathrm{~kg} \cdot \mathrm{ha}^{-1}$; em média com até $22000 \mathrm{~kg} \cdot \mathrm{ha}^{-1}$ e alta produção com $36000 \mathrm{~kg} \cdot \mathrm{ha}^{-1}$ massa verde.

UFER (1956) afirmou que os rendimentos de massa verde obtidos com o cultivo do tremoço branco doce no Brasil são variáveis dependendo do solo, clima e condições meteorológicas locais. Entretanto, para as condições do Rio Grande do sul não são raros rendimentos entre 30000 e 40000 $\mathrm{kg} \cdot \mathrm{ha}^{-1}$ de massa verde. Seja para fins de adubação verde ou forrageira, a melhor ocasião para aproveitamento da massa é após a fiór do rebento principal e princípio da formação das laterais.

Para as condições existentes no sul do pais, ANÔNIMO (1962) recomendou que o corte e enterrio da massa verde de tremoço branco, destinado a adubação verde, seja efetuado através de gradeação, aração e novamente gradeação, quando $2 / 3$ da lavoura estiver florida, sendo geralmente, para aquelas condições entre 54 e 60 dias de idade, tendo o soIo ganho cerca de $6200 \mathrm{~kg} \cdot \mathrm{ha}^{-1}$ de matéria verde cultivado com essa leguminosa.

Observação feita por LEAL (1970) nas condições do Rio Grande do sul indica que o tremoco branco produz maior quantidade de massa vegetal que o azul e amarelo, conseguindo-se rendimentos de 20000 a $40000 \mathrm{~kg} \cdot \mathrm{ha}^{-1} \mathrm{de}$ massa verde. Sendo que, o enterrio das plantas destinadas a adubação verde pode ser efetuado a partir do aparecimento da 
primeira camada de flores, o que ocorre com cerca de 3 meses de vegetação, conforme a época de semeadura.

Em experimentos realizados por WITHERS et ali1 (1974) na Nova Zelândia, os cultivares Unicrop e uniharvest, ambos pertencentes à espécie de L. angustifolius, fo ram semeados em 10 diferentes épocas, no perílodo de abril a outubro. observaram que um atrazo na época de semeadura reduziu o número de dias para o florescimento, sendo que, para as semeaduras de abril e maio houve um período de, 120 dias e 150 dias para o florescimento dos cultivares unicorp e Uniharvest, respectivamente. Entretanto, com as semeaduras de setembro e outubro, houve um periodo médio de 60 dias e 80 dias para o florescimento dos cultivares Unicrop e Unihar vest, respectivamente.

IVANOV (1975) estudou, na BuIgäria, o efeito de diferentes densidades populacionais sobre a produção de massa verde de tremoço. Trabalhou com densidades de 50 , 100, 150 e 200 sementes. $\mathrm{m}^{-2}$, obtendo producōes médias de massa verde de $11000,18000,21000$ e $24000 \mathrm{~kg} \cdot \mathrm{ha}^{-1}$, respectivamente, para cada população estudada.

Estudos foram realizados por REEVES et alii (1977) com cultivares de L. angustifolius e L. albus em diferentes localidades à nordeste de Victória - Austrália. Em 1973 efetuaram 16 épocas de semeadura, com intervalo semanal, iniciando-se em 11 de maio. Em 1974 foram efetuadas 13 épocas de semeadura, iniciando em 5 de abril até setembro, sendo as quatro primeiras semeaduras efetuadas com intervalo semanal e as demais com intervalo quinzenal. Avaliações foram efetuadas sobre a duração das diferentes fases do ciclo da planta: da semeadura à emergēncia; da emergēncia à iniciação do florescimento; da iniciação do florescimento à pri- 
meira flor; da primeira flor à última flor. para todos os cultivares estudados observou-se que quanto mais tardia foi a semeadura menor foi o ciclo da planta, sendo que as fases de iniciação do florescimento até a primeira flor e da primeira à última flor revelaram reduçōes acentuadas.

De acordo com GALETI (1979) a melhor época para a semeadura do tremoço, no Estado de são paulo, é o período de março e abril. Relatou que a produção média de massa verde é de $25000 \mathrm{~kg} \cdot \mathrm{ha}^{-1}$, recomendando o corte dessa leguminosa por ocasião de seu florescimento, sendo que para - tremoço branco essa fase ocorre naquelas condições, entre 70 a 90 dias após semeadura.

De acordo com HERBERT (1979) experimento com tremoço foi conduzido em Canterbury na Nova zelándia, com semeadura em 23 de agosto de 1976 usando espaçamento padrão de $0,15 \mathrm{~m}$ entre linhas. O L. albus cv. Ultra, foi cultivado com densidade de 10 e 94 plantas por $\mathrm{m}^{2}$, enquanto que para L. angustifolius $c v$. Unicrop a densidade foi 10 e 83 plantas. $m^{-2}$ - Para o cultivar ultra foi observado que em altas densidades houve uma redução do numero de ramos laterais. o axis da inflorescência do ramo principal alcancou maior ta manho no cV. Unicrop quando comparado com o cv. Ultra. para Unicrop foi observado um maior tamanho do axis da inflorescência principal quando cultivado em baixa densidade populacional, originando cerca de 35 flores, quando cultivado em alta densidade formou somente 28 flores.

\section{Ensaios conduzidos no IAPAR - Paraná}

DERPSCH et alii (1980) mostraram que utilizando espacamento de $0,17 \mathrm{~m}$ entre linhas com população de 63 plantas. $\mathrm{m}^{-2}$ e gasto de $140 \mathrm{~kg} \cdot \mathrm{ha}^{-1}$ de sementes, a produção de massa verde aos 96 dias de idade foi $33000 \mathrm{~kg} \cdot \mathrm{ha}^{-1}$, enquanto que aos 115 
dias foi de $46000 \mathrm{~kg} \cdot \mathrm{ha}^{-1}$. No espaçamento de $0,50 \mathrm{~m}$ entre linhas com população de 29 plantas.m ${ }^{-2}$ e gasto de $70 \mathrm{~kg} \cdot \mathrm{ha}^{-1}$ de sementes, a produção de massa verde aos 96 dias foi de $26000 \mathrm{~kg} \cdot \mathrm{ha}^{-1}$. Informaram também, que estudos realizados em cinco regiões do Estado do paraná no ano de 1979 mostraram uma produção média de $25500 \mathrm{~kg} \cdot \mathrm{ha}^{-1}$ de massa verde de L. albus.

De acordo com FLOSS (1980) para as condições do Estado do Rio Grande do sul, o cultivo do tremoço branco destinado à adubação verde pode chegar a $40000 \mathrm{~kg} \cdot \mathrm{ha}^{-1}$ de biomassa. o corte dessas plantas deve ser efetuado com o aparecimento da primeira camada de flores, o que ocorre aproximadamente aos 3 meses de vegetação, dependendo da época de semeadura. O material cortado deve ficar sobre o solo e somente ser enterrado por ocasião de seu preparo para o próximo plantio, servindo como protetor contra a ação de chuvas e raios solares.

Estudos feitos para selecionar espécies vegetais de bom crescimento no inverno, para serem utilizados no sistema agrícola Paranaense, segundo IAPAR (1980), revelaram que o rendimento médio do tremoço, L. albus, foi $27000 \mathrm{~kg}$. $\mathrm{ha}^{-1}$ de massa verde correspondendo em média a $3500 \mathrm{~kg} \cdot \mathrm{ha}^{-1}$ de matéria seca, com semeadura em julho e colhido para análise, com cerca de 80 dias de idade.

$$
\text { O florescimento do tremoço branco La albus }
$$
ocorre, nas condições do norte do Paraná, entre 50 e 70 dias após a germinação, segundo informaram MuzILLI et alii (1980). Por apresentar florescimento irregular recomendaram que a incorporação fosse feita quando $2 / 3$ da lavoura estivesse florida. A produção de massa verde, naquelas condições, está ao redor de 30000 e $40000 \mathrm{~kg} \cdot \mathrm{ha}^{-1}$, correspondendo em média a 3500 a $5000 \mathrm{~kg} \cdot \mathrm{ha}^{-1}$ de matéria seca. Análise de 15 
amostras de tremoço branco aos 90 dias de ldade, revelou a produção de $27500 \mathrm{~kg} \cdot \mathrm{ha}^{-1}$ de massa verde, contendo 12,048 de matéria seca.

Farrington citado por SCHERER (1982) relatou que a época mais apropriada para a incorporação de plantas de tremoço é o periodo do inicio ao final do florescimento, quando se atinge o máximo desenvolvimento vegetativo e acúmulo de nutrientes.

MUZILLI et alii (1983) no Estado do Paraná, realizaram estudos com L. albus para verificar o efeito do tremoço na rotação de cultura, comparado com diferentes doses de nitrogēnio, sobre o rendimento de quatro cultivares de milho. o corte e a incorporação da biomassa de tremoço foram realizados quando atingiu a fase de pleno florescimento, atingindo $27500 \mathrm{~kg} \cdot \mathrm{ha}^{-1}$ de massa verde correspondendo a $12,04 \%$ de matéria seca. Observaram que a adubação verde colocou à disposição do milho cerca de $84 \mathrm{~kg} \mathrm{ha}^{-1}$ de nitrogénio.

LOPES (1984) recomendou que adubos verdes sejam incorporados, quando a lavoura apresentar de 20 a 30 o de florescimento. Segundo o autor a quantidade de matéria orgânica que pode ser incorporada varia com o tipo de cultura, clima e solo. Dados obtidos pela EMPASC no Estado de santa Catarina informam que a produça de massa verde para o tremoco é de $10000 \mathrm{~kg} \cdot \mathrm{ha}^{-1}$.

Para as condições do Estado do paraná, IGUE et alii (1984) informaram que o ciclo do tremoco branco, até a floração plena, ocorre com 120 dias de idade e os rendimentos médios de massa verde de L. albus variaram de 20000 a $45000 \mathrm{~kg} \cdot \mathrm{ha}^{-1}$, correspondendo entre 2000 a $5000 \mathrm{~kg} \cdot \mathrm{ha}^{-1} \mathrm{de}$ 
matéria seca.

Segundo SABADIN (1984) para as condiçōes do Estado do Rio Grande do sul, o tremoço inicia florescimento cerca de 90 dias após semeadura. Entretanto, se deixado a florescer até início da formação de vagens o volume de biomassa aumenta substancialmente. Quando se desenvolve bem o tremoço alcança produçōes de massa verde de 25000 a $30000 \mathrm{~kg}$. $\mathrm{ha}^{-1}$, o que pode representar cerca de $120 \mathrm{~kg} \cdot \mathrm{ha}^{-1}$ de nitrogénio. Por ser uma leguminosa de fácil decomposição, poderá ser incorporada ao solo cerca de 30 dias antes do plantio da cultura seguinte, ou ainda ser cortado e deixado na superfície, servindo como cobertura morta.

A floração para L. albus no Estado do paranā, segundo informaram DERPSCH \& CALEGARI (1985), inicia-se dos 50 aos 70 dias após germinação. Entretanto, a época ideal para o corte é durante a floração plena, o que ocorre entre 120 a 140 dias, quando as plantas normalmente atingem altura de 0,80 a $1,50 \mathrm{~m}$. Nessas conaições a produção de massa verde atinge em média de 30000 a $40000 \mathrm{~kg} \cdot \mathrm{ha}^{-1}$, correspondendo entre 3500 a $5000 \mathrm{~kg} \cdot \mathrm{ha}^{-1}$ de matéria seca.

\subsection{Produção de sementes}

ANONIMO (1925) citou que a produção de sementes de tremoço, pode ser de 40 a $70 \mathrm{hl}^{-1} \mathrm{ha}^{-1}$, quando utilizado espacamento de $0,60 \mathrm{~m}$ entre Iinhas, com gasto de 100 litros de sementes por hectare.

Segundo CORREA (1939) o número de sementes de tremoço contidas em $1000 \mathrm{~g}$ é mais ou menos 2600 , sendo o peso do hectolitro de $74 \mathrm{~kg}$. 
Para as condições edafoclimáticas existentes no Estado do Rio Grande do Sul, UFER (1956) afirmou não ser raro, encontrar rendimentos do tremoço entre $1400 \mathrm{~kg}$ e 2000 $\mathrm{kg} \cdot \mathrm{ha}^{-1}$ de sementes.

Segundo LEAL (1970) a cultura estabelecida em junho e julho no Rio Grande do sul, amadurece em novembro e dezembro. Das espécies observadas o tremoço branco detém melhor as sementes ao completar a maturação, permitindo ser colhido mecanicamente. observou que os cultivares menos deiscentes de tremoço branco tèm proporcionado melhores coTheitas que as outras espécies, sendo que em condiçóes normais o tremoco branco produz de 1000 a $1500 \mathrm{~kg} \cdot \mathrm{ha}-1$ de sementes, enquanto que o tremoço amarelo produz de 500 a $700 \mathrm{~kg}$. $h a^{-1}$

Trabalhando com L. luteus e L. angustifolius, na Austrália, FARRINGTON (1974) concluiu que a produção de grãos dessas espēcies foi maior quando a semeadura foi realizada em março e abril, em relação àquelas efetuadas em maio e junho.

MUNTEAN (1975) trabalhando com L. albus, na Romênia em 1967/69, nas populações de 25 e 50 plantas.m ${ }^{-2}$, com espaçamentos de 0,15 e $0,60 \mathrm{~m}$ entre linhas, com plantas distanciadas de $0,15 \mathrm{~m}$, observou que, aumentando a densidade populacional de 25 para 50 plantas $\mathrm{m}^{-2}$ a média de produtividade de sementes aumentou de 2100 para $2700 \mathrm{~kg}^{\mathrm{h} \mathrm{ha}^{-1}}$.

Em experimentos conduzidos por GOULDEN (1976), na Nova zelāndia, em $1974 / 75$, L. angustifolius L. cv. Uniharvest, foi semeado em duas épocas distintas: 01.05 e 12.09; ambos com cinco taxas de semeadura: $67,101,135,168$ e 202 $\mathrm{kg} \cdot \mathrm{ha}^{-1}$ de sementes, correspondendo à populações de 16,28 , 
39, 53 e 70 plantas. ${ }^{-2}$ no florescimento para a semeadura de maio e $19,34,47,59$ e 74 plantas. ${ }^{-2}$ no florescimento, para a semeadura de setembro. A semeadura em maio proporcionou rendimentos de $3451,4152,4439,4560$ e $4848 \mathrm{~kg}^{-\mathrm{ha}^{-1}, \mathrm{res}}$ pectivamente para cada densidade populacional obtida. Com a semeadura em setembro os rendimentos foram 1962, 2874, 2947, 3255 e $3212 \mathrm{~kg} \cdot \mathrm{ha}^{-1}$. observa-se que a semeadura em maio proporcionou maiores renáimentos em relação à semeadura de setembro, em todas as densidades populacionais estudadas. verifica-se também que tanto para a semeadura em maio como em setembro, o aumento da densidade populacional ocasionou aumento na produtividade de sementes.

Estudos realizados por WITHERS et aI11 (1974) utilizando quatro cultivares de tremoco, avaliaram os efeitos de trés densidades populacionais, sobre o rendimento de sementes, sendo utilizados espaçamentos de 4,8 e $11 \mathrm{~cm}$ entre plantas, mantendo-se constante o espaçamento de $0,18 \mathrm{~m}$ entre linhas, com semeadura em 16.04., 20.07 e 02.10 . observou-se não haver diferença significativa na produtivida de entre as densidades populacionais estudadas ou entre as épocas de semeadura, embora os maiores valores absolutos de produtividade fossem encontrados com a semeadura efetuada em julho.

HERBERT (1977) realizou experimento com L.albus 'Ultra' em Canterbery - Nova Zelāndia, com semeadura em 23 de setembro de 1975, no espaçamento padrão de $0,15 \mathrm{~m}$ entre Inhas, para verificar o efeito de diferentes densidades populacionais sobre a produtividade de sementes. Seis densida des populacionais foram obtidas no momento da colheita, sendo $16,4,16,5,22,1,25,0,33,5$ e 35,6 plantas.m ${ }^{-2}$ sendo que as produtividades correspondentes, padronizadas para o mesmo teor de umidade $(14 \%)$, foram: 2137, 2023, 2729, 2508, 2782 e 
$3156 \mathrm{~kg} \cdot \mathrm{ha}^{-1}$ de sementes, respectivamente.

Estudo conduzido por HERBERT (1979) em Canterbury na Nova zelandia, utilizou para l. albus cv. Ultra, três densidades populacionais, 10,65 e 93 plantas. ${ }^{-2}$ e para L. angustifolius cv. Unicrop as densidades de 10,53 e 83 plantas. $m^{-2}$. observou que a produção de sementes por planta diminuiu com o aumento da densidade populacional, abtendo para as respectivas densidades do cv. Ultra as produçōes de $19,22,10,51$ e 7,40 gramas por planta e para cv. Unicrop: $34,31,10,99$ e 6,45 gramas por planta.

DERPSCH et alii (1980) relataram que dados obtidos na reglão Sul do Paraná em 1972 , revelaram produçóes de sementes variáveis em função do uso de adubação (N, P e e K) e calagem, sendo que em condiçōes adubadas o rendimento situou-se ao redor de $2000 \mathrm{~kg} \cdot \mathrm{ha}^{-1}$, enquanto que para condições de terreno não adubado o rendimento foi ao redor de $1500 \mathrm{~kg} \cdot \mathrm{ha}^{-1}$.

ELOSS (1980) observou que para as condições do Rio Grande do sul, a semeadura do tremoço, destinada a produção de grãos é efetuada nos meses de junho e julho, ow correndo a maturação da semente em novembro e dezembro. tremoco branco retem melhor as sementes que os tremocos azul e amarelo, sendo perfeitamente possivel sua colheita com automotriz. Em condições normais, conforme fertilidade do so10, o tremoço branco produz de 1000 a $1500 \mathrm{~kg} \cdot \mathrm{ha}^{-1}$, enquanto que o tremoco azul e amarelo variam de 500 a $700 \mathrm{~kg} \mathrm{ha}^{-1}$.

MCGIBBON \& WILLIAMS (1980) conduziram trabaTho com tremoço, L. albus, na Inglaterra para avaliar o efeito da densidade populacional sobre a produtividade de 
sementes e conteúdo de óleo. As densidades estudadas foram: 6,25 e 100 plantas. $m^{-2}$. observaram que a produção por planta, no ramo principal e nos laterais fol maior nas àreas cultiVadas com baixa densidade populacional. Diferenças entre os tratamentos foram resultantes principalmente da produção total de vagens por planta e do numero de sementes por vagem. Nos ramos terciários, a produção de sementes foi muito baixa, sendo que, nas altas densidades populacionais foi nula.

\section{Dados experimentais obtidos por BOUNDY}

et alii (1982) revelaram que na região de Victória - Austrália, o atraso da época de semeadura acarretou queda no rendimento de sementes do tremoço. Experimentos foram conduzidos com L. albus cV. Ultra em 12 épocas de semeadura sendo a primei$r a$ em 05 de abril e a ültima em 02 de setembro. As melhores produtividades foram obtidas com as semeaduras em abril, onde a maior média foi $4483 \mathrm{~kg} \cdot \mathrm{ha}^{-1}$ e a menor média foi com a semeadura em setembro com $398 \mathrm{~kg} \cdot \mathrm{ha}^{-1}$.

Para as condições do Estado do Rio Grande do Sul, TOMASINI (1982) relatou que a quantidade de sementes, espaçamento e época de semeadura são utilizados sem dados conclusivos da pesquisa, entretanto, é comum na região a semeadura no período de abril a junho com gasto médio de 120 $\mathrm{kg} \cdot \mathrm{ha}^{-1}$ de sementes, quando o objetivo é produção de grãos e em média $150 \mathrm{~kg} \cdot \mathrm{ha}^{-1}$ para produção de massa verde. A colheita mecânica tem sido realizada sem problemas no més de dezembro com rendimento em torno de $1200 \mathrm{~kg} \cdot \mathrm{ha}^{-1}$.

De acordo com SANTOS et alii (1984) ensaios conduzidos com L. albus cV. Multolupa no Estado do Rio Grande do Sul, nos espaçamentos de $0,20,0,40$ e $0,60 \mathrm{~m}$ entre $11-$ nhas, com 10 plantas por metro linear, revelaram rendimentos de 3297,3964 e $3010 \mathrm{~kg} \cdot \mathrm{ha}^{-1}$ de sementes, respectivamente. 


\section{MATFRTAL E METODO}

\subsection{Local}

o presente trabalho foi instalado no Campus da Fundação Faculdade de Agronomia "Luiz Meneghel", em área de topografia plana, no municipio de Bandeirantes - Paraná, tendo como coordenadas $23^{\circ} 06^{\prime}$ de latitude sul e longitude de $50^{\circ} 22^{\prime}$ W.Gr. a uma altitude de 440 metros.

\subsection{Clima}

Os dados médios de temperatura e precipitação (Tabela 1) foram obtidos da estação agrometeorológica de Bandeirantes, localizada no Campus da Faculdade, próximo ao local onde foi conduzido o experimento.

\section{3. Solo}

o solo, classificado como Latossolo Roxo Futrófico, com A moderado, textura muito argilosa com relevo ondulado (SILVA, 1985), foi devidamente amostrado, na profundidade de $0-0,20 \mathrm{~m}$ e a análise química realizada no laboratório do Departamento de Quimica da Escola superior de Agricultura "Luiz de Queiroz", revelando os teores contidos 
Tabela 1. Dados médios de temperatura e precipitação de Bandeirantes - PR. Periodo de 1985.

\begin{tabular}{|c|c|c|c|c|}
\hline \multirow[t]{2}{*}{ Meses } & \multicolumn{3}{|c|}{ Temperatura $\left({ }^{\circ} \mathrm{C}\right)$} & \multirow{2}{*}{$\begin{array}{r}\text { Chuva } \\
\text { (min) }\end{array}$} \\
\hline & Média & Máxima & Minima & \\
\hline Janeiro & 24,1 & 30,1 & 19,1 & 82,0 \\
\hline Fevereiro & 25,3 & 32,5 & 20,7 & 170,3 \\
\hline Março & 24,1 & 30,1 & 19,6 & 180,2 \\
\hline Abril & 22,9 & 29,2 & 18,3 & 154,5 \\
\hline Maio & 18,6 & 26,3 & 12,4 & 136,5 \\
\hline Junho & 16,3 & 23,7 & 10,4 & 21,3 \\
\hline Julho & 16,7 & 24,5 & 10,7 & 22,2 \\
\hline Agosto & 20,8 & 29,4 & 13,3 & 4,4 \\
\hline Setembro & 21,8 & 29,3 & 15,8 & 43,2 \\
\hline Outubro & 24,7 & 33,0 & 17,8 & 22,0 \\
\hline Novembro & 25,5 & 32,8 & 19,2 & 126,0 \\
\hline Dezembro & 26,0 & 33,2 & 20,1 & 47,3 \\
\hline
\end{tabular}


na Tabela 2 , podendo ser os dados assim interpretados: $\mathrm{pH}=$ acidez média; $\mathrm{M} .0 .=$ alto; $\mathrm{P}=\operatorname{médio;~} \mathrm{K}=$ baixo; $\mathrm{Ca}+\mathrm{Mg}=$ alto; saturação de bases $(\mathrm{V} \%)=$ média.

Tabela 2. Resultado da análise quimica da amostra do solo coletado à profundidade de 0 a $0,20 \mathrm{~m}$.

\begin{tabular}{|c|c|c|c|c|c|c|c|c|c|}
\hline $\begin{array}{c}\text { P } \\
\text { Resina } \\
\text { Ppm }\end{array}$ & M.O. & $\mathrm{CaCl}_{2}$ & $-\cdots--$ & $\mathrm{Ca}$ & $\frac{M g}{\text { meq }}$ & $\frac{\mathrm{H}+\mathrm{Al}}{100 \mathrm{~cm}}$ & -- & --- & $\begin{array}{l}V \\
\%\end{array}$ \\
\hline 22,1 & 4,05 & 5,10 & 0,13 & 5,11 & 1,51 & 4,01 & 6,75 & 10,81 & 62,4 \\
\hline
\end{tabular}

\section{4. Sementes}

\subsubsection{Origem}

As sementes utilizadas foram produzidas

na região de Assai - Paraná, na safra agrícola de 1984 pela "Vega Sementes e Produtos Agropecuários Ltda" de Londrina paraná.

\subsubsection{Seleção}

De posse das sementes iniciou-se um processo de seleção manual, descartando-se as danificadas e as muito pequenas, com a finalidade de homogenizar o lote quanto ao aspecto e tamanho. 


\subsubsection{Germinação}

Desse lote homogêneo tomou-se, ao acaso, amostra de 400 sementes que foi submetida ao teste de germinação, cujo resultado foi $88 \%$.

\subsubsection{Tratamento quimico}

Visando uma proteção das plântulas contra fungos causadores de tombamento (principalmente Rhizoctonia sp) as sementes foram tratadas, momentos antes da semeadura, com o fungicida Dissulfeto de Tetrametil - Tiuran "T.M.T.D." na dosagem de 300 gramas do produto comercial para $100 \mathrm{~kg}$ de sementes.

\subsection{Tratamentos}

Estudou-se o comportamento do tremoço quanto ao desenvolvimento, produção de massa verde, matéria seca e sementes em diferentes condicões.

\subsubsection{Epoca de semeadura}

Quatro épocas de semeadura foram utilizadas no periodo de março a junho de 1985, sendo:

- 1a época de semeadura em 23.03.85;

- 2a época de semeadura em 15.04.85;

- 3a época de semeadura em 18.05.85;

- 4a época de semeadura em 15.06.85. 


\subsubsection{Espaçamentos}

Para cada época de semeadura foram testados quatro espaçamentos, sendo:
1. $0,20 \mathrm{~m}$ entre linhas;
2. $0,30 \mathrm{~m}$ entre linhas;
3. $0,40 \mathrm{~m}$ entre linhas;
4. $0,50 \mathrm{~m}$ entre linhas.

3.5.3. Epoca de corte

Para a determinação da massa verde e matéria seca, realizaram-se quatro cortes em diferentes épocas, sendo:

- 10 corte aos 60 dias após emergência;

- 20 corte aos 75 dias após emergência;

- 30 corte aos 90 dias após emergência;

- 40 corte aos 105 dias após emergência.

\subsection{Instalação}

\subsubsection{Preparo do solo}

Realizado em inicio de março de 1985, constou de uma aração a $25 \mathrm{~cm}$ de profundidade, com arado fixo de 3 discos e duas gradeações niveladoras. 


\subsubsection{Semeadura}

\subsubsection{Epocas e espacamentos}

As semeaduras foram realizadas nas quatro épocas referidas em 3.5 .1 , nos espaçamentos referidos em 3 . 5.2 .

\subsubsection{Sulcamento}

Os sulcos de semeadura foram abertos manualmente, com auxilio de enxada, no espaçamento estabelecido pa ra cada tratamento. O número de sulcos foi variável em função do espaçamento adotado.

Para o tratamento de $0,20 \mathrm{~m}$ entre linhas de semeadura abriram-se 20 sulcos. Para o de $0,30,0,40$ e 0,50 $m$ entre linhas de semeadura foram abertos 16,12 e 10 sulcos respectivamente.

Quanto à profundidade dos sulcos procurou-se mantê-la entre 5 e 7 centimetros.

Todos os sulcos apresentaram $5,0 \mathrm{~m}$ de comprimento.

\subsubsection{Densidade de semeadura}

As sementes foram distribuidas manualmente uma a cada $5 \mathrm{~cm}$, com auxilio de régua previamente graduada. Dessa forma, colocaram-se 20 sementes por metro de sulco, que 
foram cobertas com uma camada de 3 a $5 \mathrm{~cm}$ de solo, sendo levemente compactadas com o pé.

\subsection{Desbaste}

Aos vinte dias após a emergência das plāntulas, realizou-se a operação de desbaste. As plantas foram seccionadas na região do colo com auxilio de faca. Não se observou nenhum caso de rebrota.

Através dessa operação, procurou-se eliminar as piores plantas e manter um espaçamento homogêneo entre as que permaneceram, tomando-se o cuidado para deixar 10 plantas por metro linear em todos os tratamentos.

\subsection{Parāmetros avaliados}

\subsubsection{Altura de planta}

Em cada parcela elegeu-se uma linha de plantas e nesta linha marcaram-se, com fitilho plástico, 20 plantas ao acaso, que foram avaliados quinzenalmente, com a primeira avaliação aos 15 dias e a última aos 120 dias após emergência.

Para a avaliação de altura, utilizou-se de uma trena de 2 metros, fixada numa haste de madeira, tomando-se as distâncias em centimetros. Duas avaliações para altura foram efetuadas, sendo: a distāncia da superficie do solo até a gema apical ou a base da inflorescência principal, conforme estádio de desenvolvimento da planta, e a ou- 
tra, da superficie do solo até o patamar das folhas mais altas da planta.

\subsubsection{Diâmetro do caule}

Para a determinação do diámetro do caule, ut lizaram-se avaliaçoes quinzenais nas mesmas 20 plantas, por parcela, marcadas para determinação da altura. As leituras foram efetuadas com um paquímetro no caule principal da planta entre 1 e $2 \mathrm{~cm}$ acima do nivel do solo. A colocação do aparelho, para efetuar a leitura, seguiu sempre uma orien tação perpendicular ao alinhamento das plantas.

\subsubsection{Produção de massa verde}

Para a determinação da produção de massa verde, efetuaram-se 4 cortes das plantas em diferentes epocas, dentro de cada parcela, aos $60,75,90$ e 105 dias após a emergência das plântulas.

Para cada época de corte elegeu-se uma linha dentro da parcela, que melhor representasse o estande na ocasião. Com auxilio de uma faca, seccionaram-se as plantas ao nivel do solo, contidas em 4 metros lineares, descartando - se 0,5 metro de cada extremidade da linha.

As plantas, imediatamente após sofrerem o corte, foram enfeixadas, identificadas com os números respectivos de cada parcela e encaminhadas ao laboratório.

$\mathrm{Na}$ determinação do peso, as plantas referentes a cada parcela, foram colocadas sobre uma balanca com preci- 
são de 0,019 e diretamente pesadas, sendo o resultado trans formado em $\mathrm{kg} \cdot \mathrm{ha}^{-1}$.

\subsubsection{Produção de matéria seca}

Em virtude do material fresco ser muito volumoso, uma amostra foi retirada e encaminhada à estufa para determinação do peso da matéria seca.

Para compor a amostra, cinco plantas foram escolhidas de cada feixe, plcadas com uma faca e acondicionadas em sacos de papel marcado com o número respectivo de cada parcela. Tomou-se o peso do material fresco dessas amostras em balança com precisão de $0,001 \mathrm{~g}$ que em seguida foram colocadas em uma estufa de ventilação forçada, com temperatura de $75^{\circ} \mathrm{C}$, onde permaneceram até o material não apresentar variação de peso. Ao final desse periodo, o material foi retirado da estufa e imediatamente pesado em balança com precisão de $0,001 \mathrm{~g}$. Os valores foram transformados em $\mathrm{kg}^{-\mathrm{ha}^{-1}}$.

\subsubsection{Produção de sementes}

O momento da colheita foi determinado pela idade das plantas, grau de desfolha e secamento, coloração das vagens, coloração e dureza das sementes.

Das Iinhas restantes na parcela, elegeu-se uma para avaliar a produção de sementes. A linha escolhida preferencialmente estava boxdejada por outras duas e procedeu-se ao arrancamento manual das plantas em 4 metros lineares descartando-se $0,5 \mathrm{~m}$ de cada extremidade. 
As plantas for am então arrancadas, contadas e transportadas para fora da parcela. De cada planta, colheram-se todas as vagens que foram colocadas em saco plástico, identificado com o número da parcela e remetido ao laboratório. Em latoratorio contou-se o número total de vagens e o número total de sementes. Após a contagem, as sementes foram pesadas em balança com precisão de $0,001 \mathrm{~g}$, sendo a produção total obtida convertendo-se o resultado em $\mathrm{kg} \cdot \mathrm{ha}^{-1}$

\subsection{Delineamento experimental}

o delineamento estatistico utilizado foi sob a forma de ensaio em parcelas subdivididas no tempo (tempo = época de cortel, em blocos casualizados, cujas parcelas estão no esquema fatorial, segundo a Tabela 3 .

\subsection{Tamanho das parcelas}

As parcelas, distribuiram-se ao acaso dentro dos blocos, medindo $5 \times 5 \mathrm{~m}=25 \mathrm{~m}^{2}$, onde 0 número de fileiras de plantas foi variāvel em função do espaçamento entre Iinhas adotado: $0,20 \mathrm{~m}, 0,30 \mathrm{~m}, 0,40 \mathrm{~m}$ e $0,50 \mathrm{~m}$ corresponden do a $20,16,12$ e 10 sulcos, respectivamente. 
Tabela 3. Esquema estatistico utilizado em blocos com parcelas subaivididas.

\begin{tabular}{|c|c|c|c|}
\hline Causas de variação & & & G.L. \\
\hline Epoca de semeadura & (E) & & 3 \\
\hline Espaçamento & (S) & & 3 \\
\hline Interação & $(E)$ & $x(S)$ & 9 \\
\hline Tratamentos & & & 15 \\
\hline Blocos & & & 2 \\
\hline Resíauo (a) & & & 30 \\
\hline Epoca de corte & (C) & & 3 \\
\hline Interação & (E) & $x \quad(C)$ & 9 \\
\hline Interação & (S) & $x \quad(C)$ & 9 \\
\hline Interação & (E) & $x \quad(S) \times(C)$ & 27 \\
\hline Residuo (b) & & & 96 \\
\hline
\end{tabular}




\section{RESULTADOS}

\subsection{Desenvolvimento das plantas}

4.1.1. Altura de plantas até a gema apical ou base da inflorescéncia principal

Os valores do teste de Fischer (F) das análises de variāncia e os coeficlentes de variação, para as avaliaçōes quinzenais para esse parâmetro, estão relacionados na Tabela 4. Observa-se que nas análises dos efeitos simples o teste $F$ foi significativo a $1 \frac{8}{\circ}$ de probabilidade para épocas de semeadura, em todas as avaliaçöes quinzenais realizadas. Para espaçamentos, somente a avaliação aos 15 dias não foi significativo, sendo que nas avaliações aos 60,75 e 90 dias o nivel de significāncia foi $5 \%$. Para a interaça épocas de semeadura versus espacamentos, somente foram significativas, ao nivel de $5 \%$ de probabilidade, as avaliaçóes aos 60,75 e 90 dias.

Os valores encontrados para esse parāmetro, foram muito variáveis. Considerando-se as avaliações após 60 dias de idade, observamos que a maior altura individual encontrada foi $1,00 \mathrm{~m}$, avaliada aos 105 dias após emergencia, no espaçamento de $0,30 \mathrm{~m}$ entre linhas com semeadura em abril. 
Tabela 4. Valores de $F$ das análises de variāncia e coeficientes de variação referen tes às avaliações quinzenais da altura até a gema apical de tremoco em Bandeirantes - $P R, 1985$.

\begin{tabular}{|c|c|c|c|c|c|c|c|c|}
\hline & \multicolumn{8}{|c|}{ Epocas de avaliação (Dias apōs emergencia) } \\
\hline & 15 & 30 & 45 & 60 & 75 & 90 & 105 & 120 \\
\hline Epoca de semeadura (E) & $66,63 * *$ & $250,04 * *$ & $57,99 * *$ & $83,57 * *$ & $120,77 * x$ & $109,46 * *$ & $113,08 * *$ & $114,10 * *$ \\
\hline Espaçamento (S) & $0,39 \mathrm{~ns}$ & $7,56 * *$ & $5,02 * *$ & $4,46 *$ & $6,48 * *$ & $4,74 * *$ & $3,94 *$ & $3,33^{*}$ \\
\hline Interação (E) x (S) & $0,4 \operatorname{lns}$ & $2,18 \mathrm{~ns}$ & $2,06 \mathrm{~ns}$ & $2,30 *$ & $2,81 *$ & $2,47 *$ & $2,13 \mathrm{~ns}$ & $1,95 \mathrm{~ns}$ \\
\hline $\mathrm{CV}(\%)$ & 13,37 & 11,35 & 10,45 & 10,79 & 9,41 & 10,96 & 11,25 & 11,18 \\
\hline
\end{tabular}

* significativo a $5 \%$ de probabilidade;

** significativo a $1 \%$ de probabilidade;

ns Não significativo. 
A menor altura encontrada foi de $0,13 \mathrm{~m}$ aos 75 dias após emergëncia, no espaçamento de $0,40 \mathrm{~m}$ entre 1 inhas, com semeadura em junho.

Pelos resultados obtidos o maior valor médio obtido da avaliação de 20 plantas foi $0,6975 \mathrm{~m}$, com leitura efetuada aos 120 dias após emergéncia, proveniente da parcela cultivada no espacamento de $0,20 \mathrm{~m}$ entre linhas e semeada em abril. A menor média foi $0,1520 \mathrm{~m}$, com leitura efetuada aos 105 dias após emergéncia, proveniente de parcela cultivada no espaçamento de $0,40 \mathrm{~m}$ entre linhas com semeadura em junho.

A análise da Tabela 5 mostra que, a avaliação desse parâmetro aos 15 dias após a emergēncia revela uma maior altura para as plantas, cuja semeadura foi feita em março, em relação às obtidas nas demais épocas de semeadura, e o menor desenvolvimento para aquelas com semeadura em maio.

Para a segunda avaliação, 30 dias após emergência, observou-se melhor desenvolvimento das plantas semeadas em março e o pior para as semeadas em maio e junho; os espacamentos de $0,20 \mathrm{~m}$ e $0,30 \mathrm{~m}$ entre linhas favoreceram a altura das plantas, em relação aos de $0,40 \mathrm{~m}$ e $0,50 \mathrm{~m}$.

A avaliação aos 45 dias após emergência, revelou maior valor médio da altura até a gema apical das plan tas semeadas em abril, e as menores alturas encontradas nas plantas semeadas em junho. As plantas cultivadas nos espaçamentos de $0,20 \mathrm{~m}$ e $0,30 \mathrm{~m}$ entre linhas de semeadura revelaram maiores alturas em relação àquelas cultivadas a $0,40 \mathrm{~m}$ e $0,50 \mathrm{~m}$.

Aos 60 dias apös emergēncia, houve signifi- 
Tabela 5. Valores médios quinzenais de altura, en centímetros, até a gema apical ou base de inflorescencia principal, de plantas de tremoço cultivadas en diferentes epo cas de semeadura e espaçamentos, en Bandeirantes-PR. 1985.

\begin{tabular}{|c|c|c|c|c|c|c|}
\hline \multirow[t]{2}{*}{ Avaliaçäo aos } & \multirow{2}{*}{$\begin{array}{l}\text { Epocas de } \\
\text { semeadura }\end{array}$} & \multicolumn{4}{|c|}{ Espasamento entre linhas (m) } & \multirow[t]{2}{*}{ Médias } \\
\hline & & 0,20 & 0,30 & 0,40 & 0,50 & \\
\hline \multirow[t]{3}{*}{$\begin{array}{l}15 \text { dias após } \\
\text { emergêncía }\end{array}$} & $\begin{array}{l}23.03 .85 \\
15.04 .85 \\
18.05 .85 \\
15.06 .85 \\
\end{array}$ & $\begin{array}{l}4,69 \\
2,77 \\
2,28 \\
3,23 \\
\end{array}$ & $\begin{array}{l}4,80 \\
2,98 \\
2,27 \\
3,36 \\
\end{array}$ & $\begin{array}{l}4,58 \\
2,94 \\
2,28 \\
2,85 \\
\end{array}$ & $\begin{array}{l}4,69 \\
2,66 \\
2,33 \\
3,46 \\
\end{array}$ & \multirow[t]{3}{*}{$\begin{array}{l}4,69 \mathrm{a} \\
2,84 \mathrm{~b} \\
2,29 \mathrm{c} \\
3,23 \mathrm{~b}\end{array}$} \\
\hline & Mëdias & 3,24 & 3,35 & $3,16^{-}$ & 3,29 & \\
\hline & DMS (Tukey & $=0,48$ & & & & \\
\hline \multirow[t]{3}{*}{$\begin{array}{l}30 \text { dias após } \\
\text { emergência. }\end{array}$} & $\begin{array}{l}23.03 .85 \\
15.04 .85 \\
18.05 .85 \\
15.06 .85 \\
\end{array}$ & $\begin{array}{r}24,16 \\
20,62 \\
7,91 \\
8,54\end{array}$ & $\begin{array}{r}22,41 \\
21,53 \\
7,73 \\
8,36 \\
\end{array}$ & $\begin{array}{r}20,93 \\
17,30 \\
6,61 \\
7,27 \\
\end{array}$ & $\begin{array}{r}18,90 \\
16,57 \\
6,98 \\
9,25 \\
\end{array}$ & \multirow[t]{3}{*}{$\begin{array}{r}21,60 \mathrm{a} \\
19,00 \mathrm{~b} \\
7,31 \mathrm{c} \\
8,35 \mathrm{c}\end{array}$} \\
\hline & Médias & $15,31 \mathrm{~A}$ & $15,01 \mathrm{~A}$ & $13,02 \mathrm{~B}$ & $12,92 \mathrm{~B}$ & \\
\hline & DMS (Tukey & $=1,77$ & & & & \\
\hline \multirow[t]{3}{*}{$\begin{array}{l}45 \text { dias após } \\
\text { emergencia }\end{array}$} & $\begin{array}{l}23.03 .85 \\
15.04 .85 \\
18.05 .85 \\
15.06 .85 \\
\end{array}$ & $\begin{array}{l}31,88 \\
34,33 \\
31,29 \\
17,63 \\
\end{array}$ & $\begin{array}{l}31,42 \\
36,92 \\
30,28 \\
17,53 \\
\end{array}$ & $\begin{array}{l}27,58 \\
31,13 \\
25,72 \\
16,18 \\
\end{array}$ & $\begin{array}{l}28,12 \\
28,42 \\
28,07 \\
21,77 \\
\end{array}$ & \multirow[t]{3}{*}{$\begin{array}{l}29,75 \text { a } \\
32,70 \text { a } \\
28,84 \text { b } \\
18,28 \text { c }\end{array}$} \\
\hline & Médias & $28,79 \mathrm{~A}$ & $29,04 \mathrm{~A}$ & $25,15 \mathrm{~B}$ & $26,59 \mathrm{AB}$ & \\
\hline & DMS (Tukey & $=3,18$ & & & & \\
\hline \multirow[t]{3}{*}{$\begin{array}{l}60 \text { dias após } \\
\text { emergència }\end{array}$} & $\begin{array}{l}23.03 .85 \\
15.04 .85 \\
18.05 .85 \\
15.06 .85 \\
\end{array}$ & $\begin{array}{l}45,65 \text { aA } \\
44,12 \text { aA } \\
47,07 \text { aA } \\
20,11 \text { bA } \\
\end{array}$ & $\begin{array}{l}36,67 \mathrm{bB} \\
44,15 \mathrm{abA} \\
47,08 \mathrm{aA} \\
21,25 \mathrm{cA} \\
\end{array}$ & $\begin{array}{l}37,40 \mathrm{aAB} \\
39,60 \mathrm{aAB} \\
41,08 \mathrm{aA} \\
18,16 \mathrm{bA}\end{array}$ & $\begin{array}{l}36,38 \mathrm{aB} \\
34,82 \mathrm{aB} \\
42,43 \mathrm{aA} \\
25,24 \mathrm{bA}\end{array}$ & \multirow[t]{3}{*}{$\begin{array}{l}39,02 \mathrm{a} \\
40,67 \mathrm{a} \\
44,42 \mathrm{a} \\
21,19 \mathrm{~b}\end{array}$} \\
\hline & Médias & $39,24 \mathrm{~A}$ & $37,29 \mathrm{~A}$ & $34,06 \mathrm{~A}$ & $34,72 \mathrm{~A}$ & \\
\hline & DMS (Tukey & )$=8,71$ & & & & \\
\hline \multirow[t]{3}{*}{$\begin{array}{l}75 \text { dias após } \\
\text { emergência }\end{array}$} & $\begin{array}{l}23.03 .85 \\
15.04 .85 \\
18.05 .85 \\
15.06 .85 \\
\end{array}$ & $\begin{array}{l}48,78 \mathrm{aA} \\
56,48 \mathrm{aA} \\
53,41 \mathrm{aA} \\
23,95 \mathrm{bA} \\
\end{array}$ & $\begin{array}{l}38,56 \mathrm{bB} \\
55,18 \mathrm{aA} \\
51,42 \mathrm{aA} \\
23,73 \mathrm{cA} \\
\end{array}$ & $\begin{array}{l}42,46 \mathrm{aAB} \\
48,35 \mathrm{aAB} \\
47,03 \mathrm{aA} \\
21,63 \mathrm{bA} \\
\end{array}$ & $\begin{array}{l}38,09 \mathrm{bB} \\
42,87 \mathrm{abB} \\
49,31 \mathrm{aA} \\
26,92 \mathrm{cA} \\
\end{array}$ & \multirow[t]{3}{*}{$\begin{array}{l}41,97 \mathrm{~b} \\
50,72 \mathrm{a} \\
50,29 \mathrm{ab} \\
24,06 \mathrm{c}\end{array}$} \\
\hline & Mëdias & $45,66 \mathrm{~A}$ & $42,22 \mathrm{~A}$ & $39,87 \mathrm{~A}$ & $39,30 \mathrm{~A}$ & \\
\hline & DMS (Tukey & $=8,74$ & & & & \\
\hline $\begin{array}{l}90 \text { dias após } \\
\text { emergencia }\end{array}$ & $\begin{array}{l}23.03 .85 \\
15.04 .85 \\
18.05 .85 \\
15.06 .85 \\
\end{array}$ & $\begin{array}{l}50,48 \mathrm{bA} \\
60,92 \mathrm{aA} \\
56,37 \mathrm{abA} \\
22,40 \mathrm{cA} \\
\end{array}$ & $\begin{array}{l}41,02 \mathrm{bAB} \\
61,55 \mathrm{aA} \\
51,88 \mathrm{aA} \\
23,73 \mathrm{cA} \\
\end{array}$ & $\begin{array}{l}46,22 \text { aAB } \\
54,17 \text { aAB } \\
48,77 \text { aA } \\
20,58 \text { bA } \\
\end{array}$ & $\begin{array}{l}39,83 \mathrm{aB} \\
46,03 \mathrm{aB} \\
50,12 \mathrm{aA} \\
26,08 \mathrm{bA}\end{array}$ & \multirow[t]{3}{*}{$\begin{array}{l}44,38 \mathrm{~b} \\
55,67 \mathrm{a} \\
51,78 \mathrm{at} \\
23,20 \mathrm{c}\end{array}$} \\
\hline \multirow[t]{2}{*}{ 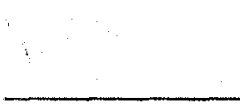 } & Médias & $47,54 \mathrm{~A}$ & $44,55 \mathrm{~A}$ & $42,43 \mathrm{~A}$ & $40,51 \mathrm{~A}$ & \\
\hline & \multicolumn{5}{|c|}{ DMS (Tukey $5 \%)=10,66$} & \\
\hline \multirow[t]{3}{*}{$\begin{array}{l}105 \text { dias após } \\
\text { emergencia }\end{array}$} & $\begin{array}{l}23.03 .85 \\
15.04 .85 \\
18.05 .85 \\
15.06 .85 \\
\end{array}$ & $\begin{array}{l}51,28 \\
62,77 \\
57,05 \\
22,48 \\
\end{array}$ & $\begin{array}{l}43,25 \\
63,40 \\
53,17 \\
22,42 \\
\end{array}$ & $\begin{array}{l}47,85 \\
55,60 \\
49,07 \\
19,57 \\
\end{array}$ & $\begin{array}{l}44,40 \\
47,42 \\
50,42 \\
25,45 \\
\end{array}$ & \multirow[t]{3}{*}{$\begin{array}{l}46,70 \mathrm{~b} \\
57,30 \mathrm{a} \\
52,42 \mathrm{a} \\
22,48 \mathrm{c}\end{array}$} \\
\hline & Médias & $48,40 \mathrm{~A}$ & $45,56 \mathrm{AB}$ & $43,02 \mathrm{AB}$ & $41,92 \mathrm{~B}$ & \\
\hline & DMS (Tukey & $=5,59$ & & & & \\
\hline \multirow[t]{3}{*}{$\begin{array}{l}120 \text { días após } \\
\text { emergencia }\end{array}$} & $\begin{array}{l}23.03 .85 \\
15.04 .85 \\
18.05 .85 \\
15.06 .85 \\
\end{array}$ & $\begin{array}{l}51,42 \\
62,55 \\
56,18 \\
22,48 \\
\end{array}$ & $\begin{array}{l}44,16 \\
63,00 \\
53,87 \\
22,42 \\
\end{array}$ & $\begin{array}{l}48,92 \\
55,20 \\
49,48 \\
19,57 \\
\end{array}$ & $\begin{array}{l}44,82 \\
48,00 \\
50,85 \\
25,45 \\
\end{array}$ & \multirow[t]{3}{*}{$\begin{array}{l}47,33 \mathrm{~b} \\
57,19 \mathrm{a} \\
52,60 \mathrm{a} \\
22,48 \mathrm{c}\end{array}$} \\
\hline & Médias & $48,16 \mathrm{~A}$ & $45,86 \mathrm{AB}$ & $43,29 \mathrm{AB}$ & $42,28 \mathrm{~B}$ & \\
\hline & DMS (Tuk & $=5,58$ & & & & \\
\hline
\end{tabular}

If Médias seguidas da mesma letra minúscula na vertical, näo diferem significativamente en2) tre si, pelo teste de Tukey a $5 \%$ de probabilidade.

2/ Médias seguidas da mesma letra maiúscula na horizontal não diferem significativanente en tre si, pelo teste de Tukey a $5 \%$ de probabilidade. 
cância da interação época de semeadura e espaçamentos, onde observou-se que, para o espaçamento de $0,20 \mathrm{~m}$ entre linhas, as semeaduras de março, abril e maio não diferiram estatisticamente, enquanto que, a semeadura de junho diferiu, revelando menor tamanho das plantas. Para os espacamentos de $0,30 \mathrm{~m}$ e $0,40 \mathrm{~m}$ os maiores valores para altura foram encontrados nas semeaduras de abril e maio, e o menor para a semeadura de junho. No espaçamento de $0,50 \mathrm{~m}$, o maior valor foi obtido com a semeadura de maio e o menor com a semeadura de junho.

Para a quinta avaliação, aos 75 dias de idade, observou-se que no espaçamento de $0,20 \mathrm{~m}$, as semeaduras de abril e maio revelaram maior valor para altura até a gema apical das plantas, sendo o menor crescimento encontrado com a semeadura em junho. Igual comportamento foi observado nos espaçamentos de $0,30 \mathrm{~m}, 0,40 \mathrm{~m}$ e $0,50 \mathrm{~m}$. Com relação às épo cas de semeadura observam-se maiores alturas das plantas semeadas em abril e maio, sendo os menores valores encontrados na semeadura de junho.

A avaliação aos 90 dias após emergência reveIou que nos espaçamentos de 0,20 e $0,30 \mathrm{~m}$, entre Iinhas de semeadura, as plantas apresentaram maiores valores de altura, em relação àquelas cultivadas no espaçamento entre linhas de $0,40 \mathrm{~m}$ e $0,50 \mathrm{~m}$. Para todos os espaçamentos adotados, as avaliações nessa data mostraram maiores valores para altura das plantas semeadas em abril e maio e os menores para as plantas semeadas em junho.

Aos 105 dias de idade, os maiores valores foram encontrados no espaçamento entre linhas de $0,20 \mathrm{~m}$ e os menores valores no espaçamento de $0,50 \mathrm{~m}$. Os maiores valores para altura até a gema apical das plantas foram encontra dos nas semeaduras de abril e maio, sendo o menor valor en- 
contrado com a semeadura de junho.

A avaliação aos 120 dias após emergência mostrou comportamento semelhante aquele aos 105 dias de idade: obtendo-se maior valor para altura das plantas, quando cultivadas no espaçamento de $0,20 \mathrm{~m}$ e o menor valor quando à 0,50 m entre linhas. Os maiores valores de altura até a gema apical das plantas foram encontrados com a semeadura de abril e maio e o menor valor com a semeadura de junho, independentemente do espaçamento adotado.

\subsubsection{Altura total de plantas}

Na Tabela 6, encontram-se os valores de $\mathrm{F}$ obtidos nas análises de variāncia dos dados referentes à altura total de plantas e os respectivos coeficientes de variacão. A análise do efeito simples de épocas de semeadura revelou-o significativo ao nível de $1 \%$ de probabilidade para todas as avaliaçōes quinzenais efetuadas. o efeito simples de espaçamentos foi significativo a $1 \%$ de probabilidade aos 30 dias e a $5 \%$ aos 45 dias, sendo nas demais avaliações não significativo. A interação épocas de semeadura versus espacamentos mostrou-se significativa, ao nivel de $1 \%$ de probabilidade, somente aos 45 dias.

Na população estudada observou-se grande variação na altura total de plantas, uma vez que o maior valor individualmente encontrado foi $1,36 \mathrm{~m}$, sendo essa planta cutlivada no espaçamento de $0,20 \mathrm{~m}$ entre linhas e com semeadura em marco. O menor valor encontrado foi $0,19 \mathrm{~m}$, cultivada no espaçamento de $0,40 \mathrm{~m}$ com semeadura em junho. 
Tabela 6. Valores de $F$ das análises de variāncia e coeficientes de variação referen tes às avaliações quinzenais da altura total de plantas de tremoco em Ban deirantes - PR, 1985.

\begin{tabular}{|c|c|c|c|c|c|c|c|c|}
\hline & \multicolumn{8}{|c|}{ Epocas de avaliação (Dias após emergentcia) } \\
\hline & 15 & 30 & 45 & 60 & 75 & 90 & 105 & 120 \\
\hline Epoca de semeadura (E) & $6,08 * *$ & $154,23 * *$ & $58,22 * *$ & $106,51 * *$ & $138,14 * *$ & $132,24 * *$ & $205,95 * *$ & $206,92 * x$ \\
\hline Espaçamento (S) & $0,35 \mathrm{~ns}$ & $7,16 * *$ & $4,15^{*}$ & $2,09 \mathrm{~ns}$ & $1,47 \mathrm{~ns}$ & $0,6 \operatorname{lns}$ & $0,79 \mathrm{~ns}$ & $0,69 \mathrm{~ns}$ \\
\hline Interação (E) x (S) & $0,26 \mathrm{~ns}$ & $2,00 \mathrm{~ns}$ & $2,44 *$ & $2,08 \mathrm{~ns}$ & $2,00 \mathrm{~ns}$ & $1,84 \mathrm{~ns}$ & $1,56 \mathrm{~ns}$ & $1,62 \mathrm{~ns}$ \\
\hline $\mathrm{CV}(\%)$ & 8,83 & 9,42 & 9,12 & 9,58 & 8,85 & 10,22 & 8,99 & 9,12 \\
\hline
\end{tabular}

* significativo a $5 \%$ de probabilidade;

** significativo a $1 \%$ de probabilidade;

ns não significativo. 
plantas avaliadas por parcela, encontrou-se como maior $1,0140 \mathrm{~m}$, proveniente de parcela cultivada a $0,20 \mathrm{~m}$ de espacamento entre linhas e semeadura em abril. o menor valor médio foi $0,2215 \mathrm{~m}$, obtido em parcela cultivada no espacamen to de $0,40 \mathrm{~m}$ entre linhas com semeadura em junho.

De acordo com a Tabela 7, a avaliação aos 15 dias após emergência mostrou que o crescimento das plantas foi semelhante em todos os espaçamentos efetuados. Em relação as épocas de semeadura, observa-se uma pequena supremacia daquelas plantas semeadas em abril.

Aos 30 dias após emergência observa-se melhor desenvolvimento na altura das plantas, nos espaçamentos de $0,20 \mathrm{~m}$ e $0,30 \mathrm{~m}$, em relação a $0,40 \mathrm{~m} \mathrm{e} 0,50 \mathrm{~m}$. Os maiores valores para altura das plantas foram encontrados com as semeaduras realizadas em marco e abril, sendo os menores valores encontrados na semeadura de junho, confirmado em todos os espaçamentos testados.

Aos 45 dias após emergēncia, os espaçamentos de $0,20 \mathrm{~m}$ e $0,30 \mathrm{~m}$ entre linhas de semeadura, proporcionaram os maiores valores para altura de plantas. Em todos os espaçamentos estudados, os maiores, valores para altura de plantas foram encontrados na semeadura de abril e os menores com a semeadura de junho.

A quarta avaliação, aos 60 dias de idade, revelou que, embora não havendo diferença estatistica entre os espaçamentos testados, houve uma tendência na redução do valor médio da altura de plantas, à medida que se aumentou o espaçamento entre linhas de $0,20 \mathrm{~m}$ para $0,50 \mathrm{~m}$. com relação às épocas de semeadura observou-se uma pequena supremacia na altura média das plantas, quando semeadas em março, em rela- 
Tabela 7. Valores médios quinzenais da altura total, em centínetros, de plantas de tremoso cultivadas em diferentes eppocas de semeadura e espaçamentos, em Bandeirantes PR. 1985.

\begin{tabular}{|c|c|c|c|c|c|c|}
\hline \multirow[t]{2}{*}{ Avaliaçäo aos } & \multirow{2}{*}{$\begin{array}{l}\text { Epocas de } \\
\text { semeadura }\end{array}$} & \multicolumn{4}{|c|}{ Espacamento entre Iinhas (m) } & \multirow[t]{2}{*}{ Médias } \\
\hline & & 0,20 & 0,30 & 0,40 & 0,50 & \\
\hline \multirow[t]{3}{*}{$\begin{array}{l}15 \text { d as após } \\
\text { emergencia }\end{array}$} & $\begin{array}{l}23.03 .85 \\
15.04 .85 \\
18.05 .85 \\
15.06 .85 \\
\end{array}$ & $\begin{array}{r}9,97 \mathrm{~b} \\
11,60 \mathrm{a} \\
10,46 \mathrm{~b} \\
9,89 \mathrm{~b} \\
\end{array}$ & $\begin{array}{r}9,91 \mathrm{~b} \\
11,28 \mathrm{a} \\
10,29 \mathrm{~b} \\
9,87 \mathrm{~b} \\
\end{array}$ & $\begin{array}{r}9,46 \mathrm{~b} \\
11,32 \mathrm{a} \\
9,74 \mathrm{~b} \\
9,94 \mathrm{~b} \\
\end{array}$ & $\begin{array}{r}9,94 \mathrm{a} \\
10,78 \mathrm{a} \\
9,97 \mathrm{a} \\
10,24 \mathrm{a} \\
\end{array}$ & \multirow[t]{3}{*}{$\begin{array}{r}9,82 \mathrm{~b} \\
11,24 \mathrm{a} \\
10,12 \mathrm{~b} \\
9,98 \mathrm{~b}\end{array}$} \\
\hline & Médias & 10,48 & 10,34 & 10,11 & 10,23 & \\
\hline & DMS (Tukey & $\%)=2,20$ & & & & \\
\hline \multirow[t]{3}{*}{$\begin{array}{l}30 \text { dias após } \\
\text { emergëncia }\end{array}$} & $\begin{array}{l}23.03 .85 \\
15.04 .85 \\
18.05 .85 \\
15.06 .85 \\
\end{array}$ & $\begin{array}{l}30,28 \\
28,55 \\
17,21 \\
13,52 \\
\end{array}$ & $\begin{array}{l}28,47 \\
29,31 \\
17,30 \\
13,63 \\
\end{array}$ & $\begin{array}{l}26,91 \\
24,79 \\
14,63 \\
12,38 \\
\end{array}$ & $\begin{array}{l}24,48 \\
23,37 \\
15,62 \\
14,98 \\
\end{array}$ & \multirow[t]{3}{*}{$\begin{array}{l}27,53 \mathrm{a} \\
26,50 \mathrm{a} \\
16,19 \mathrm{~b} \\
13,62 \mathrm{c}\end{array}$} \\
\hline & Médias & $22,39 \mathrm{~A}$ & $22,18 \mathrm{~A}$ & $19,68 \mathrm{~B}$ & $19,61 \mathrm{~B}$ & \\
\hline & DMS (Tukey & $\%=2,20$ & & & & \\
\hline \multirow[t]{3}{*}{$\begin{array}{l}45 \text { dias após } \\
\text { emergencia }\end{array}$} & $\begin{array}{l}23.03 .85 \\
15.04 .85 \\
18.05 .85 \\
15.06 .85 \\
\end{array}$ & $\begin{array}{l}39,84 \mathrm{abA} \\
44,93 \mathrm{aA} \\
37,72 \mathrm{bA} \\
24,53 \mathrm{cAB} \\
\end{array}$ & $\begin{array}{l}38,86 \mathrm{bA} \\
47,27 \mathrm{aA} \\
36,79 \mathrm{bA} \\
24,92 \mathrm{cAB}\end{array}$ & $\begin{array}{l}36,50 \mathrm{abA} \\
40,27 \mathrm{aAB} \\
32,14 \mathrm{bA} \\
22,88 \mathrm{cB}\end{array}$ & $\begin{array}{l}36,76 \text { aA } \\
37,00 \text { aB } \\
34,91 \text { aA } \\
30,10 \text { aA }\end{array}$ & \multirow[t]{3}{*}{$\begin{array}{l}37,99 \mathrm{a} \\
42,37 \mathrm{a} \\
35,39 \text { a } \\
25,61 \mathrm{~b}\end{array}$} \\
\hline & Médias & $36,75 \mathrm{~A}$ & $36,96 \mathrm{~A}$ & $32,95 \mathrm{~A}$ & $34,69 \mathrm{~A}$ & \\
\hline & DMS (Tukey & $\%)=7,16$ & & & & \\
\hline \multirow[t]{3}{*}{$\begin{array}{l}60 \text { dias após } \\
\text { emergencia }\end{array}$} & $\begin{array}{l}23.03 .85 \\
15.04 .85 \\
18.05 .85 \\
15.06 .85 \\
\end{array}$ & $\begin{array}{l}65,08 \\
62,25 \\
55,67 \\
26,85 \\
\end{array}$ & $\begin{array}{l}60,77 \\
60,55 \\
56,33 \\
29,27 \\
\end{array}$ & $\begin{array}{l}60,95 \\
54,53 \\
51,52 \\
25,89 \\
\end{array}$ & $\begin{array}{l}59,28 \\
49,08 \\
53,22 \\
35,22 \\
\end{array}$ & \multirow[t]{3}{*}{$\begin{array}{l}61,52 \text { a } \\
56,60 \text { a } \\
54,18 \text { b } \\
29,31 \mathrm{c}\end{array}$} \\
\hline & Médias & 52,46 & 31,73 & 48,22 & 49,20 & \\
\hline & DMS (Tukey & $\%)=5,37$ & & & & \\
\hline \multirow[t]{3}{*}{$\begin{array}{l}75 \text { dias após } \\
\text { emergência }\end{array}$} & $\begin{array}{l}23.03 .85 \\
15.04 .85 \\
18.05 .85 \\
15.06 .85 \\
\end{array}$ & $\begin{array}{l}80,16 \\
80,22 \\
66,40 \\
33,83 \\
\end{array}$ & $\begin{array}{l}71,62 \\
80,12 \\
66,46 \\
34,65 \\
\end{array}$ & $\begin{array}{l}74,27 \\
73,98 \\
63,11 \\
32,08 \\
\end{array}$ & $\begin{array}{l}72,85 \\
65,67 \\
67,02 \\
40,13 \\
\end{array}$ & \multirow[t]{3}{*}{$\begin{array}{l}74,72 \text { a } \\
75,00 \text { a } \\
65,74 \text { b } \\
35,17 \text { c }\end{array}$} \\
\hline & Médias & 65,15 & 63,21 & 60,86 & $6 \mathrm{I}, 42$ & \\
\hline & DMS (Tukey & $\%)=6,16$ & & & & \\
\hline \multirow[t]{3}{*}{$\begin{array}{l}90 \text { dias após } \\
\text { emergéncia }\end{array}$} & $\begin{array}{l}23.03 .85 \\
15.04 .85 \\
18.05 .85 \\
15.06 .85 \\
\end{array}$ & $\begin{array}{l}88,93 \\
88,03 \\
70,42 \\
31,78 \\
\end{array}$ & $\begin{array}{l}75,97 \\
90,88 \\
70,60 \\
35,13 \\
\end{array}$ & $\begin{array}{l}82,55 \\
85,57 \\
66,57 \\
31,52 \\
\end{array}$ & $\begin{array}{l}80,05 \\
75,15 \\
70,30 \\
40,57 \\
\end{array}$ & \multirow[t]{3}{*}{$\begin{array}{l}81,87 \mathrm{a} \\
84,91 \mathrm{a} \\
69,47 \mathrm{~b} \\
34,75 \mathrm{c}\end{array}$} \\
\hline & Médias & 69,79 & 68,15 & 66,55 & 66,52 & \\
\hline & DMS (Tukey & $5 \%=7,70$ & & & & \\
\hline \multirow[t]{3}{*}{$\begin{array}{l}\text { 105 dias após } \\
\text { emergencia }\end{array}$} & $\begin{array}{l}23.03 .85 \\
15.04 .85 \\
18.05 .85 \\
15.06 .85 \\
\end{array}$ & $\begin{array}{l}90,67 \\
91,93 \\
69,83 \\
31,50 \\
\end{array}$ & $\begin{array}{l}85,30 \\
93,40 \\
70,27 \\
32,16 \\
\end{array}$ & $\begin{array}{l}84,98 \\
90,12 \\
68,15 \\
29,12 \\
\end{array}$ & $\begin{array}{l}84,35 \\
78,30 \\
70,43 \\
37,88 \\
\end{array}$ & \multirow[t]{3}{*}{$\begin{array}{l}86,32 \mathrm{a} \\
88,44 \mathrm{a} \\
69,67 \mathrm{~b} \\
32,66 \mathrm{c}\end{array}$} \\
\hline & Médias & 70,98 & 70,28 & 68,09 & 67,74 & \\
\hline & DMS (Tukey & $5 \%)=6,92$ & & & & \\
\hline \multirow[t]{3}{*}{$\begin{array}{l}120 \text { dias após } \\
\text { emergēncia }\end{array}$} & $\begin{array}{l}23.03 .85 \\
15.04 .85 \\
18.05 .85 \\
15.06 .85 \\
\end{array}$ & $\begin{array}{l}92,55 \\
91,92 \\
69,83 \\
31,50 \\
\end{array}$ & $\begin{array}{l}86,87 \\
93,87 \\
69,03 \\
32,16 \\
\end{array}$ & $\begin{array}{l}87,55 \\
92,65 \\
67,13 \\
29,12 \\
\end{array}$ & $\begin{array}{l}85,18 \\
78,87 \\
69,92 \\
37,88 \\
\end{array}$ & \multirow[t]{3}{*}{$\begin{array}{l}88,04 \text { a } \\
89,32 \text { a } \\
68,98 \text { b } \\
32,66 \text { c }\end{array}$} \\
\hline & Médias & 71,45 & 70,48 & 69,11 & 67,96 & \\
\hline & DMS (Tuk & $\%)=7$, & & & & \\
\hline
\end{tabular}

If Médias seguidas da mesma letra minúscula na vertical, nāo diferem significativamente en 2) tre si, pelo teste de Tukey a $5 \%$ de probabilidade.

2) Médias seguidas da mesma letra maiúscula na horizontal näo diferem significativamente entre si, pelo teste de Tukey a $5 \%$ de probabilidade. 
cão àquelas semeadas em abril e maio, sendo estas, bem superiores àquelas resultantes da semeadura realizada em junho.

Aos 75 dias após emergência, as plantas cultivadas no espacamento entre linhas de semeadura de $0,20 \mathrm{~m}$ e $0,30 \mathrm{~m}$ revelaram maior valor de altura, quando comparadas àquelas cultivadas nos espaçamentos de $0,40 \mathrm{~m} \mathrm{e} 0,50 \mathrm{~m}$, excessão feita ao espaçamento de $0,50 \mathrm{~m}$ nas semeaduras de maio e junho. Quanto às épocas de semeadura, observa-se pelos valores médios da altura total das plantas que a semeaduras de março e abril proporcionaram maiores valores, em relação àquelas semeadas em maio e junho, independentemente do espacamento adotado.

Aos 90 dias de idade, as plantas mostraram através de sua altura média, que ocorreu uma ligeira superio ridade quando cultivadas à $0,20 \mathrm{~m}$ e $0,30 \mathrm{~m}$, sobre aquelas cultivadas a $0,40 \mathrm{~m} e 0,50 \mathrm{~m}$, entre linhas. As semeaduras realizadas em março e abril proporcionaram maiores valores médios para altura total das plantas, sendo que os valores encontrados para plantas semeadas em junho foram inferiores aqueles das outras épocas de semeadura.

De acordo com a avaliação aos 105 dias após emergēncia, as plantas cultivadas com espaçamento de $0,20 \mathrm{~m}$ e $0,30 \mathrm{~m}$ entre linhas tiveram valores de altura total ligeiramente superiores àquelas encontradas quando as plantas foram cultivadas no espaçamento de $0,40 \mathrm{~m}$ e $0,50 \mathrm{~m}$. Para todos os espaçamentos entre linhas testados, verificou-se que, as semeaduras de março e abril proporcionaram maiores valores para altura das plantas, enquanto que, os menores foram encontrados na semeadura em junho.

A última avaliação, realizada aos 120 dias 
após emergència, revelou pequena supremacia no valor da altura total das plantas, quando cultivadas nos espacamentos de $0,20 \mathrm{~m}$ e $0,30 \mathrm{~m}$ sobre àquelas cultivadas a $0,40 \mathrm{~m}$ e 0,50 m. Quanto às épocas de semeadura, observa-se que, as semeaduras de marco e abril revelaram os maiores valores médios para altura total, enquanto que, os valores encontrados para as plantas semeadas em junho foram bem inferiores aos encontrados nas outras trés épocas de semeadura.

\subsubsection{Diāmetro do caule}

os valores de $F$ e os coeficientes de variação das análises de variancia (Tabela 8) referentes aos dados de diāmetro do caule de plantas de tremoço, revelaram que para o efeito simples de épocas de semeadura foi significativo a $1 \%$ de probabilidade para todas as avaliações quinzenais realizadas. O efeito simples de espacamentos mostrou-se significativo a 1 응 de probabilidade, com exceção à avaliação efetuada aos 15 dias. O efeito da interação épocas de semeadura versus espaçamentos, revelou ser significativo a $5 \%$ na avaliação aos 60 dias, sendo não significativo nas demais avaliações.

Houve grande variação no valor do diāmetro do caule das plantas de tremoço, observando-se o maior valor individual de $1,37 \mathrm{~cm}$, com a planta cultivada no espaçamento de $0,50 \mathrm{~m}$ entre linhas e semeadura em abril. o menor valor individual foi $0,29 \mathrm{~cm}$, de planta cultivada no espacamento de $0,30 \mathrm{~m}$ com semeadura em junho.

A determinação de valor médio desse parâmetro foi efetuada pela média de 20 plantas por parcela. o maior valor médio encontrado foi $0,88 \mathrm{~cm}$, proveniente de parcela 
Tabela 8. Valores de $F$ das anälises de variância e coeficientes de variação referen tes às avaliações quinzenais do diametro do caule de plantas de tremoço, em Bandeirantes - PR, 1985.

\begin{tabular}{|c|c|c|c|c|c|c|c|c|}
\hline & \multicolumn{8}{|c|}{ Epocas de avaliação (Dias após emergencia) } \\
\hline & 15 & 30 & 45 & 60 & 75 & 90 & 105 & 120 \\
\hline Epoca de semeadura (E) & $15,95 * *$ & $165,97 * *$ & $66,76 * *$ & $37,35 *$ & $31,68 * *$ & $65,55 * *$ & $130,59 * x$ & $133,29 * *$ \\
\hline Espaçamento (S) & $0,16 \mathrm{~ns}$ & $5,56 * *$ & $6,28+x$ & $6,93 * \pi$ & $8,79 * *$ & $10,09 * x$ & $13,11 * *$ & $11,71 * *$ \\
\hline Interação (E) x (S) & $0,97 \mathrm{~ns}$ & $1,72 \mathrm{~ns}$ & $1,01 \mathrm{~ns}$ & $0,19 *$ & $0,34 \mathrm{~ns}$ & $0,70 \mathrm{~ns}$ & $0,33 \mathrm{~ns}$ & $0,55 \mathrm{~ns}$ \\
\hline $\mathrm{CV}(\%)$ & 6,60 & 4,39 & 5,43 & 6,78 & 7,52 & 7,55 & 6,71 & 7,27 \\
\hline
\end{tabular}

* significativo a $5 \%$ de probabilidade;

** significativo a $1 \%$ de probabilidade;

ns não significativo. 
cultivada no espaçamento de $0,40 \mathrm{~m}$ entre Iinhas com semeadura em abril. o menor valor médio encontrado foi $0,40 \mathrm{~cm}$, proveniente de parcela cultivada no espacamento de $0,40 \mathrm{~m}$ e semeadura en junho.

$A$ análise dos dados contidos na tabela 9 , revelam que aos 15 dias após emergēncia, as semeaduras de abril e maio proporcionaram plantas com maior valor médio para diâmetro do caule. Quanto aos espaçamentos adotados, observou-se uma tendência dos maiores valores para diâmetro nos maiores espaçamentos.

Aos 30 dias de idade, não se observa, com clareza, predomináncia de um espaçamento sobre outro, em fun ção dos valores médios obtidos. para as épocas de semeadura, nota-se uma pequena superioridade dos valores encontrados para a semeadura de abril em relação às demais.

Aos 45 dias após emergēncia, observa-se que os maiores valores médios foram obtidos no espaçamento de $0,30 \mathrm{~m}$ e $0,50 \mathrm{~m}$, em relação aos de $0,40 \mathrm{~m}$ e $0,20 \mathrm{~m}$. Quanto às épocas de semeadura, observam-se os maiores valores médios para as plantas semeadas em abril.

A avaliação aos 60 dias após emergēncia, revela uma redução do valor médio do diâmetro do caule, à medida que se diminui o espaçamento de $0,50 \mathrm{~m}$ para $0,20 \mathrm{~m}$, sendo os maiores valores encontrados para o espacamento entre Iinhas de $0,50 \mathrm{~m}$ e os menores no espaçamento de $0,20 \mathrm{~m}$. Apesar de não haver diferença estatística para as épocas de semeadura de março, abril e maio, em valores absolutos, a semeadura de abril proporcionou maiores valores médios, sendo que, a semeadura em junho apresentou valores bem inferiores aqueles encontrados nas demais épocas. 
Tabela 9. Valores médios quinzenais do diametro do caule, em centímetros, de plantas de tremoço cultivadas em diferentes épocas de semeadura e espaçamentos, em Bandeirantes-PR, 1985.

\begin{tabular}{|c|c|c|c|c|c|c|}
\hline \multirow[t]{2}{*}{ Avaliação aos } & \multirow{2}{*}{$\begin{array}{l}\text { Epoca de } \\
\text { semeadura }\end{array}$} & \multicolumn{4}{|c|}{ Espacamentos entre linhas (m) } & \multirow[t]{2}{*}{ Mèdias } \\
\hline & & 0,20 & 0,30 & 0,40 & 0,50 & \\
\hline \multirow[t]{3}{*}{$\begin{array}{l}15 \text { dias após } \\
\text { emergencia. }\end{array}$} & $\begin{array}{l}23.03 .85 \\
15.04 .85 \\
18.05 .85 \\
15.06 .85 \\
\end{array}$ & $\begin{array}{l}0,350 \\
0,363 \\
0,357 \\
0,303\end{array}$ & $\begin{array}{l}0,300 \\
0,363 \\
0,363 \\
0,323 \\
\end{array}$ & $\begin{array}{l}0,330 \\
0,370 \\
0,360 \\
0,307 \\
\end{array}$ & $\begin{array}{l}0,330 \\
0,367 \\
0,360 \\
0,313 \\
\end{array}$ & \multirow[t]{3}{*}{$\begin{array}{l}0,327 \mathrm{~b} \\
0,366 \mathrm{a} \\
0,360 \mathrm{a} \\
0,312 \mathrm{~b}\end{array}$} \\
\hline & Médias & 0,342 & 0,337 & 0,342 & 0,342 & \\
\hline & DMS (Tukey & $5 \%=0,0250$ & & & & \\
\hline \multirow[t]{3}{*}{$\begin{array}{l}30 \text { dias após } \\
\text { emergencia }\end{array}$} & $\begin{array}{l}23.03 .85 \\
15.04 .85 \\
18.05 .85 \\
15.06 .85 \\
\end{array}$ & $\begin{array}{l}0,380 \\
0,473 \\
0,380 \\
0,310\end{array}$ & $\begin{array}{l}0,430 \\
0,503 \\
0,380 \\
0,340 \\
\end{array}$ & $\begin{array}{l}0,400 \\
0,487 \\
0,370 \\
0,323 \\
\end{array}$ & $\begin{array}{l}0,387 \\
0,490 \\
0,387 \\
0,357 \\
\end{array}$ & \multirow[t]{3}{*}{$\begin{array}{l}0,399 \mathrm{~b} \\
0,488 \mathrm{a} \\
0,379 \mathrm{c} \\
0,332 \mathrm{~d}\end{array}$} \\
\hline & Médias & $0,386 \mathrm{~B}$ & $0,413 \mathrm{~A}$ & $0,395 \mathrm{AB}$ & $0,405 \mathrm{AB}$ & \\
\hline & DMS (Tukey & $5 \%)=0,019$ & & & & \\
\hline \multirow[t]{3}{*}{$\begin{array}{l}45 \text { dias após } \\
\text { emergencia. }\end{array}$} & $\begin{array}{l}23.03 .85 \\
15.04 .85 \\
18.05 .85 \\
15.06 .85 \\
\end{array}$ & $\begin{array}{l}0,497 \\
0,523 \\
0,397 \\
0,387\end{array}$ & $\begin{array}{l}0,537 \\
0,560 \\
0,440 \\
0,423 \\
\end{array}$ & $\begin{array}{l}0,510 \\
0,537 \\
0,433 \\
0,397 \\
\end{array}$ & $\begin{array}{l}0,520 \\
0,530 \\
0,450 \\
0,457\end{array}$ & \multirow[t]{3}{*}{$\begin{array}{l}0,516 \mathrm{a} \\
0,537 \mathrm{a} \\
0,430 \mathrm{~b} \\
0,416 \mathrm{~b}\end{array}$} \\
\hline & Médias & $0,451 \mathrm{~B}$ & $0,490 \mathrm{~A}$ & $0,469 \mathrm{AB}$ & $0,489 \mathrm{~A}$ & \\
\hline & DMS (Tukey & $5 \%=0,029$ & & & & \\
\hline \multirow[t]{3}{*}{$\begin{array}{l}60 \text { dias após } \\
\text { emergencia }\end{array}$} & $\begin{array}{l}23.03 .85 \\
15.04 .85 \\
18.05 .85 \\
15.06 .85\end{array}$ & $\begin{array}{l}0,530 \mathrm{aA} \\
0,603 \mathrm{aA} \\
0,533 \mathrm{aA} \\
0,430 \mathrm{bA}\end{array}$ & $\begin{array}{l}0,573 \mathrm{aA} \\
0,627 \mathrm{aA} \\
0,583 \mathrm{aA} \\
0,467 \mathrm{bA} \\
\end{array}$ & $\begin{array}{l}0,593 \mathrm{aA} \\
0,660 \mathrm{aA} \\
0,590 \mathrm{aA} \\
0,483 \mathrm{bA}\end{array}$ & $\begin{array}{l}0,593 \mathrm{aA} \\
0,643 \mathrm{aA} \\
0,613 \mathrm{aA} \\
0,507 \mathrm{bA}\end{array}$ & \multirow[t]{3}{*}{$\begin{array}{l}0,572 \\
0,633 \\
0,580 \\
0,472\end{array}$} \\
\hline & Médias & $0,524 \mathrm{~A}$ & $0,562 \mathrm{~A}$ & $0,582 \mathrm{~A}$ & $0,589 \mathrm{~A}$ & \\
\hline & DMS (Tukey & $5 \%)=0,086$ & & & & \\
\hline \multirow[t]{3}{*}{$\begin{array}{l}75 \text { dias após } \\
\text { emergência }\end{array}$} & $\begin{array}{l}23.03 .85 \\
15.04 .85 \\
18.05 .85 \\
15.06 .85 \\
\end{array}$ & $\begin{array}{l}0,553 \\
0,633 \\
0,540 \\
0,453\end{array}$ & $\begin{array}{l}0,617 \\
0,650 \\
0,603 \\
0,577 \\
\end{array}$ & $\begin{array}{l}0,623 \\
0,703 \\
0,613 \\
0,500 \\
\end{array}$ & $\begin{array}{l}0,657 \\
0,690 \\
0,643 \\
0,550 \\
\end{array}$ & \multirow[t]{3}{*}{$\begin{array}{l}0,612 \\
0,669 \\
0,600 \\
0,495\end{array}$} \\
\hline & Médias & $0,545 \mathrm{~B}$ & $0,587 \mathrm{AB}$ & $0,610 \mathrm{~A}$ & $0,635 \mathrm{~A}$ & \\
\hline & DMS (Tukey & $5 \%=0,050$ & & & & \\
\hline \multirow[t]{3}{*}{$\begin{array}{l}90 \text { dias após } \\
\text { emergencia. }\end{array}$} & $\begin{array}{l}23.03 .85 \\
15.04 .85 \\
18.05 .85 \\
15.06 .85 \\
\end{array}$ & $\begin{array}{l}0,573 \\
0,687 \\
0,517 \\
0,433 \\
\end{array}$ & $\begin{array}{l}0,650 \\
0,693 \\
0,570 \\
0,467 \\
\end{array}$ & $\begin{array}{l}0,667 \\
0,763 \\
0,580 \\
0,480 \\
\end{array}$ & $\begin{array}{l}0,733 \\
0,740 \\
0,610 \\
0,520 \\
\end{array}$ & \multirow[t]{3}{*}{$\begin{array}{l}0,656 \\
0,721 \\
0,569 \\
0,475\end{array}$} \\
\hline & Médias & $0,552 \mathrm{C}$ & $0,595 \mathrm{BC}$ & $0,622 \mathrm{AB}$ & $0,651 \mathrm{~A}$ & \\
\hline & DMS (Tuke) & $5 \%=0,0510$ & & & & \\
\hline \multirow[t]{3}{*}{$\begin{array}{l}105 \text { dias apōs } \\
\text { emergencia }\end{array}$} & $\begin{array}{r}23.03 .85 \\
15.04 .85 \\
18.05 .85 \\
15.05 .85 \\
\end{array}$ & $\begin{array}{l}0,627 \\
0,690 \\
0,530 \\
0,377 \\
\end{array}$ & $\begin{array}{l}0,690 \\
0,703 \\
0,570 \\
0,420 \\
\end{array}$ & $\begin{array}{l}0,713 \\
0,773 \\
0,603 \\
0,437 \\
\end{array}$ & $\begin{array}{l}0,737 \\
0,763 \\
0,623 \\
0,490 \\
\end{array}$ & \multirow[t]{3}{*}{$\begin{array}{l}0,692 \\
0,732 \\
0,582 \\
0,431\end{array}$} \\
\hline & Médias & $0,556 \mathrm{C}$ & $0,596 \mathrm{BC}$ & $0,632 \mathrm{AB}$ & $0,653 \mathrm{~A}$ & \\
\hline & DMS (Tuke) & $5 \%)=0,460$ & & & & \\
\hline \multirow[t]{3}{*}{$\begin{array}{l}120 \text { dias após } \\
\text { emergéncia }\end{array}$} & $\begin{array}{l}23.03 .85 \\
15.04 .85 \\
18.05 .85 \\
15.06 .85 \\
\end{array}$ & $\begin{array}{l}0,647 \\
0,700 \\
0,507 \\
0,377 \\
\end{array}$ & $\begin{array}{l}0,730 \\
0,703 \\
0,537 \\
0,420 \\
\end{array}$ & $\begin{array}{l}0,740 \\
0,793 \\
0,563 \\
0,437 \\
\end{array}$ & $\begin{array}{l}0,767 \\
0,780 \\
0,597 \\
0,490 \\
\end{array}$ & \multirow[t]{3}{*}{$\begin{array}{l}0,721 \\
0,744 \\
0,551 \\
0,431\end{array}$} \\
\hline & Médias & $0,557 \mathrm{C}$ & $0,597 \mathrm{BC}$ & $0,633 \mathrm{AB}$ & $0,658 \mathrm{~A}$ & \\
\hline & DMS (Tuk & $5 \%)=0,050$ & & & & \\
\hline
\end{tabular}

Médias seguidas da mesma letra minúscula na vertical, não diferem significativamente entre 2 si, pelo teste de Tukey a $5 \%$ de probabilidade.

2 Médias seguidas da mesma letra maíuscula na horizontal näo diferem significativamente entre si, pelo teste de Tukey a $5 \%$ de probabilidade. 
Aos 75 dias de idade, observa-se que, os espaçamentos de $0,50 \mathrm{~m}$ e $0,40 \mathrm{~m}$ entre linhas de semeadura,proporcionam maiores valores médios para o diàmetro do caule. A semeadura de abril proporcionou maior valor médio, sendo que, os menores valores foram obtidos nas plantas da semeadura em junho.

A avaliação aos 90 dias após emexgência revela que, no espacamento de $0,50 \mathrm{~m}$ entre linhas de semeadura, as plantas apresentaram maior valor médio para diāmetro, e que à medida que se diminuiu o espaçamento entre linhas, houve redução no valor médio do diámetro do caule. os maiores valores foram observados nas plantas com semeadura em abril, $e$ os menores encontrados nas plantas semeadas em junho.

Aos 105 dias de idade, nota-se um aumento do valor do diámetro do caule com o aumento do espacamento de semeadura, sendo portanto, os maiores valores encontrados nas plantas cultivadas à $0,50 \mathrm{~m}$ e os menores no espaçamento de $0,20 \mathrm{~m}$. Com relação às épocas de semeadura, os maiores valores foram encontrados nas plantas da semeadura de abril, sendo os menores encontrados na semeadura de junho.

"Segundo a avaliação aos 120 dias de idade, os maiores valores para diâmetro do caule foram obtidos no espaçamento entre linhas de $0,50 \mathrm{~m}$, sendo os menores encontrados no espaçamento de $0,20 \mathrm{~m}$. Os maiores valores médios para diāmetro do caule foram obtidos com as semeaduras de marco e abril e os menores com as de maio e junho, sendo que, plantas de caule mais finos ocorreram com a semeadura em junho.

Um exame conjunto de todas as épocas de avaliação contidas na Tabela 9 , revela uma relação inversa en- 
tre o aumento de plantas por área e o diâmetro do caule.

\subsection{População de plantas na avaliação do rendimento de massa verde e matéria seca}

Na Tabela 10, encontram-se os valores de $F$ e os coeficientes de variação, obtidos na análise de variância para densidade populacional de tremoço, revelando para os efeitos simples de épocas de semeadura e espaçamentos, ser significativo a $1 \%$ de probabilidade, enquanto que para épocas de corte não foi significativo. Os efeitos de interação revelaram que para épocas de semeadura versus espaçamentos ; espaçamentos versus épocas de corte e épocas semeadura versus espaçamentos versus épocas de corte não foram significativos, entretanto, épocas de semeadura versus épocas de corte foi significativo ao nivel de $1 \%$ de probabilidade.

De acordo com a Tabela 11, a maior população média das plantas foi obtida com a semeadura em abril e a menor com a semeadura de junho. Quanto aos espaçamentos utilizados, observou-se a maior população média no espaçamento de 0,20 m entre linhas e a menor densidade populacional média encontrada no espaçamento de $0,50 \mathrm{~m}$, sendo esta população inferior à metade daquela existente no espaçamento de $0,20 \mathrm{~m}$.

Na Tabela 12 observam-se os valores da densidade populacional relacionando épocas de semeadura versus epocas de corte. Apesar da interação ter sido significativa a variação na população média foi pequena. Para os diferentes cortes efetuados nas plantas semeadas em marco, a maior população foi no corte aos 90 dias. As semeaduras de abril e maio não mostraram diferença significativa no valor de 
Tabela 10. Valores de $F$ das análises de variância e coeficientes de variação referentes aos dados de densidade populacional, rendimento de massa verde e matéria seca de tremoço em Bandeirantes-PR, 1985.

\begin{tabular}{|c|c|c|c|}
\hline Parämetro & $\begin{array}{l}\text { População } \\
\text { plantas.ha-1 }\end{array}$ & $\begin{array}{c}\text { Massa verde } \\
\mathrm{kg} \cdot \mathrm{ha}^{-1}\end{array}$ & $\begin{array}{l}\text { Matérla seca } \\
\text { kg.ha-1 }\end{array}$ \\
\hline $\begin{array}{l}\text { Fpoca de } \\
\text { semeadura (E) }\end{array}$ & $24,43 * *$ & $752,22 * *$ & $643,28 * *$ \\
\hline Espacamento (S) & $20048,30 * *$ & $98,96 * *$ & $182,59 * *$ \\
\hline Epoca de corte (C) & $0,86 \mathrm{~ns}$ & $136,35^{*} *$ & $299,59 * *$ \\
\hline $\begin{array}{l}\text { Interação } \\
\text { (E) } \times \text { (S) }\end{array}$ & $1,59 \mathrm{~ns}$ & $10,57 * *$ & $9,40^{* *}$ \\
\hline $\begin{array}{l}\text { Interacão } \\
\text { (E) } \times \text { (C) }\end{array}$ & $4,67 * *$ & $90,09 * *$ & $100,98^{* *}$ \\
\hline $\begin{array}{l}\text { Interação } \\
\text { (S) } \times \text { (C) }\end{array}$ & $\cdots 0,71 \mathrm{~ns}$ & $0,83 \mathrm{~ns}$ & $1,26 \mathrm{~ns}$ \\
\hline $\begin{array}{l}\text { Interação } \\
\begin{array}{l}\text { (E) } \times(\mathrm{S}) \times(\mathrm{C})\end{array}\end{array}$ & $1,18 \mathrm{~ns}$ & $1,39 \mathrm{~ns}$ & $2,17 * *$ \\
\hline $\mathrm{CV}(8) \mathrm{a}$ & 2,03 & 14,21 & 11,78 \\
\hline $\mathrm{b}$ & 1,62 & 12,25 & 11,18 \\
\hline
\end{tabular}

* significativo a $5 \%$ de probabilidade;

* significativo a 18 de probabilidade;

ns não significativo. 
Tabela 11. Valores médios das populaçōes de plantas de tremoço por hectare para épocas de semeadura versus espaçamentos, em Bandeirantes-PR, 1985.

\begin{tabular}{|c|c|c|c|c|c|}
\hline \multirow[t]{2}{*}{ Epocas de semeadura } & \multicolumn{4}{|c|}{ Espaçamentos entre Iinhas (m) } & Médias \\
\hline & 0.20 & 0,30 & 0,40 & 0,50 & \\
\hline 23.03 .85 & 489.583 & 322.917 & 244.271 & 197.917 & $313.672 \mathrm{~b}$ \\
\hline 15.04 .85 & 497.917 & 331.944 & 245.833 & 197.083 & $318.194 \mathrm{a}$ \\
\hline 18.05 .85 & 497.917 & 327.778 & 246.354 & 198.333 & $317.595 \mathrm{ab}$ \\
\hline 15.06 .85 & 484.375 & 318.750 & 235.417 & 190.833 & $307.344 \mathrm{c}$ \\
\hline Médias & $492.448 \mathrm{~A}$ & $325.347 \mathrm{~B}$ & $242.969 \mathrm{C}$ & 196.042 & \\
\hline
\end{tabular}

dms (Tukey $5 \%)=3 ; 261$

OBS.: Os dados foram transformados em $\sqrt{x+0,5}$, para análise de variância. 
Tabela 12. Valores médios das populações de plantas de tremoço por hectare para épocas de semeadura versus épocas de corte, em Bandeirantes-PR, 1985.

\begin{tabular}{|c|c|c|c|c|c|}
\hline \multirow[t]{2}{*}{ Epocas de semeadura } & \multicolumn{4}{|c|}{ Epocas de corte (aias após emergência) } & \multirow[t]{2}{*}{ Médias } \\
\hline & 60 & 75 & 90 & 105 & \\
\hline 23.03 .85 & $311.840 \mathrm{bcB}$ & $310.174 \mathrm{bB}$ & $317.882 \mathrm{aA}$ & $314.792 \mathrm{abAB}$ & $313.672 \mathrm{a}$ \\
\hline 15.04 .85 & 319.271 aA & 320.417 aA & $316.180 \mathrm{aA}$ & 316.910 aA & $318.194 \mathrm{a}$ \\
\hline 18.05 .85 & $317.361 \mathrm{abB}$ & $318.958 \mathrm{aA}$ & $318.507 \mathrm{aA}$ & $315.556 \mathrm{aA}$ & $317.595 \mathrm{a}$ \\
\hline 15.06 .85 & $311.562 \mathrm{cA}$ & $303.854 \mathrm{CC}$ & $304.51 .4 \mathrm{bBC}$ & $309.444 \mathrm{bAB}$ & $307.344 \mathrm{~b}$ \\
\hline Médias & $315.009 \mathrm{~A}$ & $313.351 \mathrm{~A}$ & $314.271 \mathrm{~A}$ & $314.175 \mathrm{~A}$ & \\
\hline
\end{tabular}

dms (Tukey 5\%) - épocas de semeadura dentro de épocas de corte $=5,177$.

dms (Tukey 5\%) - épocas de corte dentro de épocas de semeadura $=4,759$.

OBS.: Os dados foram transformados em $\sqrt{x+0,5}$, para análise de variância. 
suas populações nas diferentes épocas de corte, entretanto, em valor absoluto as maiores populações foram constatadas no corte aos 75 dias. para a semeadura de junho a maior densidade populacional foi obtida no corte aos 60 dias. com o corte das plantas aos 60 dias a maior população foi constatada na semeadura de abril e a menor com a semeadura de junho. Aos 75 dias as maiores populações foram observadas para as semeaduras de abril e maio e a menor população para a semeadura de junho. Aos 90 dias não houve diferença estatistica entre as populações das semeaduras realizadas em março, abril e maio; para junho a população além de ser menor, diferiu estatisticamente. Aos 105 dias a maior população ocorreu com a semeadura de abril e a menor com a semeadura de junho.

A análise dos dados contidos na Tabela 13, revela que a maior população média foi obtida no espaçamento de $0,20 \mathrm{~m}$ entre Iinhas e à medida que se aumentou o espaçamento houve redução na densidade populacional, verificando-se a menor população no espaçamento de $0,50 \mathrm{~m}$, sendo esta densidade inferior à metade daquela obtida com o espaçamento de $0,20 \mathrm{~m}$ entre linhas.

\subsection{Produção de massa verde}

Os valores de $F$ das análises de variância e os coeficientes de variação, para as avaliações de rendimento de massa verde de tremoço, estão contidos na Tabela 10 . os efeitos simples épocas de semeadura, espaçamentos e épocas de corte, mostraram-se significativos ao nivel de 18 de probabilidade. As interações épocas de semeadura versus espaçamentos e épocas de semeadura versus épocas de corte foram significativas a $1 \frac{0}{\circ}$ de probabilidade, enquanto que as 
Tabela 13. Valores médios das populações de plantas de tremoço por hectare para espaçamentos e épocas de corte, em Bandeirantes-PR, 1985.

\begin{tabular}{|c|c|c|c|c|c|}
\hline \multirow{2}{*}{$\begin{array}{l}\text { Espaçamento de } \\
\text { semeadura }\end{array}$} & \multicolumn{4}{|c|}{ Épocas de corte (dias após emergência) } & \multirow[t]{2}{*}{ Médias } \\
\hline & 60 & 75 & 90 & 105 & \\
\hline 0,20 & 493.750 & 489.583 & 493.750 & 492.708 & 492.448 a \\
\hline 0,30 & 326.389 & 325.694 & 325.000 & 324.306 & $325.347 \mathrm{~b}$ \\
\hline 0,40 & 243.299 & 242.708 & 241.667 & 244.271 & $242.969 \mathrm{C}$ \\
\hline 0,50 & 196.667 & 195.417 & 196.667 & 195.417 & $196.042 \mathrm{~d}$ \\
\hline Médias & 315.009 & 313.351 & 314.271 & 314.175 & \\
\hline
\end{tabular}

dms (Tukey 58) $=3,261$.

OBS.: Os dados foram transformados em $\sqrt{x+0,5}$, para análise de variāncia. 
interações espaçamentos versus épocas de corte e épocas de semeadura versus espaçamentos versus épocas de corte, nâo fo ram significativos.

O maior rendimento de massa verde foi 44.322 $\mathrm{kg} \cdot \mathrm{ha}^{-1}$ obtido de uma parcela cultivada no espaçamento de $0,30 \mathrm{~m}$ entre linhas, semeadura em marco como corte das plantas aos 105 dias. o menor rendimento foi $1.065 \mathrm{~kg} \cdot \mathrm{ha}^{-1}$, cons tatado numa parcela semeada em junho no espaçamento de 0,50 m entre linhas com o corte das plantas aos 105 dias.

o maior rendimento médio de massa verde foi $42.032 \mathrm{~kg} \cdot \mathrm{ha}^{-1}$, obtido de parcelas semeadas em março, no espaçamento de $0,30 \mathrm{~m}$ entre linhas, com o corte das plantas aos 105 dias de idade. O menor rendimento médio foi 1.275 $\mathrm{kg} \cdot \mathrm{ha}^{-1}$, obtido de parcelas semeadas em junho com espacamento de $0,40 \mathrm{~m}$ entre linhas e corte aos 105 dias após emergência (Tabela 24).

A Tabela 14 apresenta os valores médios para massa verde, na interação épocas de semeadura versus espaçamentos. Para o espaçamento de $0,20 \mathrm{~m}$ entre linhas, observa- se que as semeaduras de março e abril não diferiram estatisticamente, embora em valor absoluto a semeadura de março tenha proporcionado maior produção, e a semeadura de junho apresentando valor bem inferior às demais épocas. A $0,30 \mathrm{~m}$ de espaçamento observa-se que houve diferença significativa para todas as épocas, sendo a melhor a de março a pior a de junho. Os espaçamentos de $0,40 \mathrm{~m}$ e $0,50 \mathrm{~m}$ revelaram valores de produção semelhante para as semeaduras de março e abril, que foram superiores aos de maio e junho, tendo esta última época proporcionado valores de produça de massa verde bem inferiores às demais épocas. Para todas as épocas de 
Tabela 14. Valores médios da produção de massa verde, em $\mathrm{kg} \cdot \mathrm{ha}^{-1}$ de plantas de tre moço para épocas de semeadura versus espaçamentos, em Bandeirantes - PR, 1985 .

\begin{tabular}{|c|c|c|c|c|c|c|}
\hline \multirow{2}{*}{$\begin{array}{l}\text { Epocas de } \\
\text { semeadura }\end{array}$} & \multicolumn{5}{|c|}{ Espaçamentos entre linhas (m) } & Médias \\
\hline & 0,20 & & 0,30 & 0,40 & 0,50 & \\
\hline 23.03 .85 & 31.095 & $\mathrm{aA}$ & $28.898 \mathrm{aA}$ & $21.520 \mathrm{aB}$ & $18.884 \mathrm{aB}$ & 25.099 \\
\hline 15.04 .85 & 29.812 & $a A$ & $24.377 \mathrm{bB}$ & $22.527 \mathrm{aB}$ & $18.882 \mathrm{aC}$ & 23.900 \\
\hline 18.05 .85 & 15.823 & $\mathrm{bA}$ & $12.961 \mathrm{cB}$ & $11.414 \mathrm{bB}$ & $10.407 \mathrm{bB}$ & 12.6511 \\
\hline 15.06 .85 & 7.092 & $\mathrm{CA}$ & $5.458 \mathrm{dAB}$ & $4.631 \mathrm{CAB}$ & $4.385 \mathrm{cB}$ & 5.392 \\
\hline Médias & 20.956 & A & $17.923 \mathrm{~B}$ & $15.023 \mathrm{C}$ & $13.140 \mathrm{C}$ & \\
\hline
\end{tabular}

ams (Tukey 58) $=2,647$ 
semeadura estudadas observa-se que, o aumento do espaçamento de $0,20 \mathrm{~m}$ para $0,50 \mathrm{~m}$ acarretou diminuição no valor da produ ção de massa verde. Desta forma, à $0,20 \mathrm{~m}$ são encontrados os maiores valores e à $0,50 \mathrm{~m}$ os menores.

Os valores médios da produção de massa verde na interação época de semeaduras e épocas de corte, encontram-se na Tabela 15. A semeadura de março proporcionou maior producão de massa verde com $\rho$ corte das plantas feito aos 105 dias de idade, sendo a menor produção obtida aos 60 dias após emergência. Para a semeadura de abril a maior pro dução foi obtida aos 90 dias após emergência e a menor com 0 corte aos 60 dias. A semeadura em maio proporcionou maior produção de massa verde aos 90 dias e não diferiu daquela obtida aos 75 dias, revelando a menor produção aos 105 dias de idade. A semeadura em junho mostrou maior produção de massa verde aos 75 dias após emergência, não diferindo estatisticamente daquela obtida aos 60 dias, sendo o menor valor encontrado com o corte das plantas aos 105 dias após emergên cia. Com o corte realizado aos 60 e 75 dias após emergéncia - maior valor de produção foi obtido com a semeadura de abril e o menor com a semeadura de junho. Para os cortes realizados aos 90 e 105 dias obteve-se maiores produçōes para a semeadura de março e menores com a semeadura em junho.

De acordo com a Tabela 16, à medida que se au mentou o espaçamento houve um declínio na produção de massa verde. Assim, a maior produção média foi obtida no espaçamento de $0,20 \mathrm{~m}$ e a menor no espaçamento de $0,50 \mathrm{~m}$. Em relação à época de corte, o maior valor médio da produção foi obtido com plantas aos 90 dias de idade, sendo o menor obtido com o corte feito aos 60 dias após emergéncia. 
Tabela 15. Valores médios da produção de massa verde, em $\mathrm{kg} \cdot \mathrm{ha}^{-1}$, de plantas de tre moço para épocas de semeadura versus épocas de corte, em Bandeirantes $\mathrm{PR}, 1985$.

\begin{tabular}{lccccc}
\hline $\begin{array}{l}\text { Epocas de } \\
\text { semeadura }\end{array}$ & \multicolumn{4}{c}{ Epocas de corte (dias após emergência) } & Médias \\
\cline { 2 - 6 } & $13.218 \mathrm{bD}$ & $20.355 \mathrm{bC}$ & $31.953 \mathrm{aB}$ & $34.892 \mathrm{aA}$ & $25.099 \mathrm{a}$ \\
\hline 23.03 .85 & $16.526 \mathrm{aC}$ & $25.988 \mathrm{aB}$ & $28.248 \mathrm{bA}$ & $24.837 \mathrm{bB}$ & $23.900 \mathrm{a}$ \\
15.04 .85 & $11.322 \mathrm{bB}$ & $14.382 \mathrm{CA}$ & $15.357 \mathrm{CA}$ & $9.544 \mathrm{CB}$ & $12.651 \mathrm{~b}$ \\
18.05 .85 & $6.848 \mathrm{CAB}$ & $7.735 \mathrm{dA}$ & $5.352 \mathrm{~dB}$ & $1.632 \mathrm{dC}$ & $5.392 \mathrm{C}$ \\
15.06 .85 & $11.978 \mathrm{C}$ & $17.110 \mathrm{~B}$ & $20.227 \mathrm{~A}$ & $17.726 \mathrm{~B}$ \\
\hline
\end{tabular}

ams (Tukey 5\%) - Epocas de semeadura dentro de épocas de corte $=2,243$.

ams (Tukey 58) - Epocas de corte dentro de épocas de semeadura $=2,194$ 
Tabela 16. Valores médios da produção de massa verde, em $\mathrm{kg} \cdot \mathrm{ha}^{-1}$ de plantas de tremoço para espaçamentos e épocas de corte, em Bandeirantes - PR, 1985.

\begin{tabular}{|c|c|c|c|c|c|}
\hline \multirow{2}{*}{$\begin{array}{c}\text { Espaçamentos } \\
\text { entre linhas } \\
\text { (m) }\end{array}$} & \multicolumn{4}{|c|}{ Epocas de corte (dias após emergência) } & \multirow[t]{2}{*}{ Médias } \\
\hline & 60 & 75 & 90 & 105 & \\
\hline 0,20 & 16.273 & 21.873 & 24.765 & 20.911 & $20.956 \mathrm{a}$ \\
\hline 0,30 & 13.232 & 18.437 & 21.028 & 18.996 & $17.923 \mathrm{~b}$ \\
\hline 0,40 & 10.362 & 14.955 & 18.620 & 16.155 & $15.023 \mathrm{C}$ \\
\hline 0,50 & 8.045 & 13.176 & 16.496 & 14.842 & $13.140 \mathrm{~d}$ \\
\hline Médias & $11.978 \mathrm{C}$ & $17.110 \mathrm{~B}$ & $20.227 \mathrm{~A}$ & 17.726 & \\
\hline
\end{tabular}

dms (Tukey 5\%) - Entre as médias para espaçamentos $=1,324$.

dms (Tukey 5\%) - Entre as médias para épocas de corte $=1,097$. 


\subsection{Produção de matéria seca}

De acordo com a Tabela 10 , os valores de $\mathrm{F}$ e os coeficientes de variação da análise de variáncia para rendimento de matéria seca, revelam que o efeito simples para época de semeadura, espaçamento época de corte, foram todos significativos a $1 \%$ de probabilidade. As interaçós épocas de semeadura versus espaçamentos; épocas de semeadura versus épocas de corte e épocas de, semeadura versus espaçamento versus épocas de corte foram todos significativos a $1 \%$ de probabilidade, enquanto que a interação espaçamentos versus épocas de corte não foi significativo para o teste $F$.

O maior rendimento para matéria seca fol 8512 $\mathrm{kg} \cdot \mathrm{ha}^{-1}$, obtido de uma parcela semeada em abril no espaçamento de $0,20 \mathrm{~m}$ entre Iinhas, com o corte das plantas aos

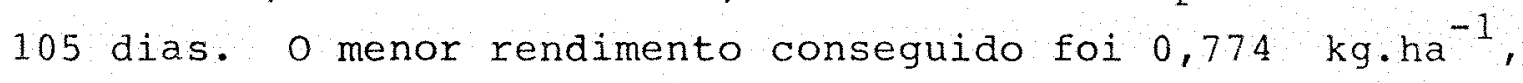
proveniente de uma parcela semeada em junho, cultivada no espaçamento de $0,50 \mathrm{~m}$ entre linhas, com o corte das plantas aos 60 dias.

o maior rendimento médio de matéria seca foi $7.970 \mathrm{~kg} \cdot \mathrm{ha}^{-1}$, obtido de parcelas semeadas em março, cultivadas no espaçamento de $0,20 \mathrm{~m}$ entre linhas e o corte das plantas efetuado aos 105 dias. O menor rendimento médio foi $1.007 \mathrm{~kg} \cdot \mathrm{ha}^{-1}$ revelado pela média de parcelas semeadas em junho, cultivadas no espaçamento de $0,50 \mathrm{~m}$ entre 1 inhas, com o corte das plantas aos 60 dias (Tabela 25).

Através da Tabela 17 observa-se que, os valores médios da produção de matéria seca em $\mathrm{kg} \mathrm{ha}^{-1}$, na intexação épocas de semeadura versus espaçamentos, no espaçamento de $0,20 \mathrm{~m}$ as produções obtidas com as semeaduras de março e abril não diferiram estatisticamente. Em valor ab- 
Tabela 17. Valores médios da produção de matéria seca, em $\mathrm{kg} \cdot \mathrm{ha}^{-1}$, de plantas de tremoço para épocas de semeadura versus espaçamentos, em Bandeirantes - PR, 1985 .

\begin{tabular}{|c|c|c|c|c|c|}
\hline \multirow{2}{*}{$\begin{array}{l}\text { Epocas de } \\
\text { semeadura }\end{array}$} & \multicolumn{4}{|c|}{ Espaçamentos entre Iinhas (m) } & \multirow[t]{2}{*}{ Médias } \\
\hline & 0,20 & 0,30 & 0,40 & 0,50 & \\
\hline 23.03 .85 & $5.283 \mathrm{aA}$ & $4.743 \mathrm{aB}$ & $3.592 \mathrm{aC}$ & $3.064 \mathrm{aD}$ & $4.171 \mathrm{a}$ \\
\hline 15.04 .85 & $5.625 \mathrm{aA}$ & $4.499 \mathrm{aB}$ & $4.005 \mathrm{aC}$ & $3.373 \mathrm{aD}$ & $4.375 \mathrm{a}$ \\
\hline 18.05 .85 & $3.441 \mathrm{bA}$ & $2.739 \mathrm{bB}$ & $2.342 \mathrm{bBC}$ & $2.056 \mathrm{bC}$ & $2.644 \mathrm{~b}$ \\
\hline 15.06 .85 & $1.973 \mathrm{cA}$ & $1.546 \mathrm{CB}$ & $1.224 \mathrm{CB}$ & $1.164 \mathrm{cB}$ & $1.477 \mathrm{c}$ \\
\hline Médias & $4.080 \mathrm{~A}$ & $3.382 \mathrm{~B}$ & $2.791 \mathrm{C}$ & $2.414 \mathrm{C}$ & \\
\hline
\end{tabular}

dms $($ Tukey 58$)=0,415$ 
soluto a semeadura de abril revelou ser maior, e a de junho menor. Para os espaçamentos a $0,30 \mathrm{~m}$ as semeaduras de marco e abril não diferiram estatisticamente, embora em valor absoluto, a semeadura de março tenha alcançado maior valor para matéria seca, e a de junho menor valor. os espaçamentos. de $0,40 \mathrm{~m}$ e $0,50 \mathrm{~m}$ revelaram que o major valor de produça de matéria seca foi obtido com a semeadura de abril, entretanto, não diferiram estatisticamente dos valores obtidos com a semeadura em março, revelando também, para estes espaçamentos, os menores valores de ṕrodução de matéria seca na semeadura efetuada em junho.

os valores médios da produção de matéria seca em $\mathrm{kg} \cdot \mathrm{ha}^{-1}$, contidos na Tabela 18 , mostram que as maiores produçoes foram obtidas com as semeaduras em abril e maio e a menor com a semeadura de junho, com corte feito aos 60 dias de idade. Para os cortes efetuados aos 75 e 90 dias após emergência, conseguiu-se a maior produção de matéria seca com a semeadura de abril, ficando em segundo lugar, a produção das plantas com semeadura em março, tendo a semeadura de junho revelado a menor produção. Aos 105 dias, a máxima produção foi obtida na semeadura de março, sendo que, o atraso na época da semeadura acarretou redução na produção de matéria seca, sendo o menor valor encontrado para a semea dura realizada em junho. As semeaduras feitas em março e abril atingiram uma máxima produção de matéria seca aos 105 dias após emergência, enquanto que, a semeadura de maio apre sentou maior valor para matéria seca aos 90 dias após emergência. A semeadura de junho não apresentou diferença significativa para os valores de produção de matéria seca com os cortes realizados aos $60,75,90$ e 105 dias após emergéncia, entretanto, o maior valor absoluto foi obtido com o corte das plantas aos $75^{\circ}$ dias de idade. 
Tabela 18. Valores médios da produção de matéria seca, em $\mathrm{kg}_{\text {.ha }}^{-1}$, de plantas de tremoco para épocas de semeadura versus épocas de corte, em Bandeiran tes $-\mathrm{PR}, 1985$.

\begin{tabular}{|c|c|c|c|c|c|c|c|}
\hline \multirow{2}{*}{$\begin{array}{l}\text { Epocas de } \\
\text { semeadura }\end{array}$} & \multicolumn{6}{|c|}{ Epocas de corte (aias após emergência) } & \multirow[t]{2}{*}{ Médias } \\
\hline & 60 & & 75 & & 90 & 105 & \\
\hline 23.03 .85 & 1.960 & $\mathrm{bD}$ & 3.183 & $\mathrm{bc}$ & $4.901 \mathrm{bB}$ & $6.638 \mathrm{aA}$ & $4.171 \mathrm{a}$ \\
\hline 15.04 .85 & 2.397 & $\mathrm{aC}$ & 4.322 & $a B$ & $5.377 \mathrm{aA}$ & $5.405 \mathrm{bA}$ & 4.375 a \\
\hline 18.05 .85 & 2.285 & $a b c$ & 2.694 & $\mathrm{aB}$ & $3.125 \mathrm{cA}$ & $2.474 \mathrm{CBC}$ & $2.644 \mathrm{~b}$ \\
\hline 15.06 .85 & 1.453 & $\mathrm{CA}$ & 1.546 & $d A$ & $1.429 \mathrm{dA}$ & $1.479 \mathrm{dA}$ & $1.477 \mathrm{C}$ \\
\hline Médias & 2.024 & $\mathrm{C}$ & 2.936 & $\mathrm{~B}$ & $3.708 \mathrm{~A}$ & $3.999 \mathrm{~A}$ & \\
\hline
\end{tabular}

dns (Tukey 5\%) - Epocas de semeadura dentro de épocas de corte $=0,376$.

dms (Tukey 5\%) - Epocas de corte dentro de épocas de semeadura $=0,378$. 
Tabela 19. Valores médios da produção de matéria seca, em $\mathrm{kg} \mathrm{ha}^{-1}$, de plantas de tremoco para espacamentos versus épocas de corte, em Bandeirantes-PR, 1985

\begin{tabular}{|c|c|c|c|c|c|}
\hline \multirow{2}{*}{$\begin{array}{l}\text { Espaçamentos } \\
\text { entre Iinhas } \\
\qquad(\mathrm{m})\end{array}$} & \multicolumn{4}{|c|}{ Epocas de corte (dias após emerqēncia) } & \multirow[t]{2}{*}{ Médias } \\
\hline & 60 & 75 & 90 & 105 & \\
\hline 0,20 & 2.789 & 3.839 & 4.611 & 5.083 & $4.080 \mathrm{a}$ \\
\hline 0,30 & 2.166 & 3.181 & 3.936 & 4.244 & $3.382 \mathrm{~b}$ \\
\hline 0,40 & 1.778 & 2.561 & 3.372 & $3-452$ & $2.791 \mathrm{c}$ \\
\hline 0,50 & 1.363 & 2.164 & 2.912 & 3.217 & $2.414 d$ \\
\hline Médias & $2.024 \mathrm{D}$ & 2.936 & $3.708 \mathrm{~B}$ & $3.999 \mathrm{~A}$ & \\
\hline
\end{tabular}

dms (Tukey 5\%) - Entre as médias para espaçamento $=0,207$

dms (Tukey 5\%) - Entre as médias para as épocas de corte $=0,189$. 
4.5. Populaçóes de plantas na ocasião da colheita de sementes

Os valores do teste das análises de variancia e o coeficiente de variação para populacão de plantas de tremoço na ocasiāo da colheita (Tabela 20), revelaram para os efeitos simples épocas de semeadura e espacamentos com significância a $1 \%$ de probabilidade, enquanto que a interação época de semeadura versus espaçamento não fol significativa.

Tabela 20. Valores de F das análises de variância e coeficientes de variação referentes à populacão de plan tas e rendimento de sementes de tremoço, em Bandeirantes-PR, 1985 .

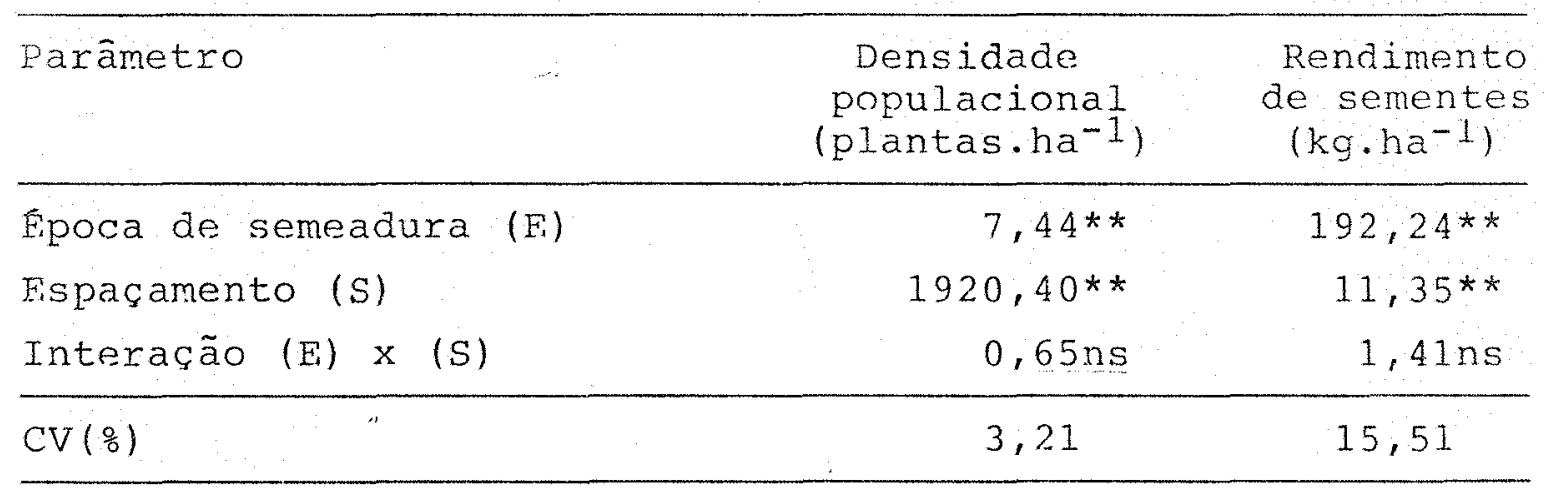

* significativo a $5 \%$ de probabilidade.

* significativo a 18 de probabilidade.

ns não significativo.

A Tabela 21 mostra valores médios da população de plantas no momento da colheita para a avaliaça ão da producão de sementes, sendo as maiores populações encontradas nos menores espacamentos. 
Tabela 21. Valores mëdios da população por hectare de plantas de tremoço cultivado em diferentes épocas de semeadura e espacamentos na ocasião da colheita de sementes, em Bandeirantes-PR, 1985.

\begin{tabular}{|c|c|c|c|c|c|}
\hline \multirow{2}{*}{$\begin{array}{l}\text { Epocas de } \\
\text { semeadura }\end{array}$} & \multicolumn{4}{|c|}{ Espacamentos entre Iinhas (m) } & \multirow[t]{2}{*}{ Médias } \\
\hline & 0,20 & 0,30 & 0,40 & 0,50 & \\
\hline 23.03 .85 & 479.167 & 322.222 & 239.583 & 191.667 & $308.160 \mathrm{ab}$ \\
\hline 15.04 .85 & 466.667 & 313.889 & 237.500 & 196.667 & $303.680 \mathrm{bc}$ \\
\hline 18.05 .85 & 491.667 & 327.777 & 245.833 & 198.333 & $315.903 \mathrm{a}$ \\
\hline 15.06 .85 & 466.667 & 305.556 & 231.250 & 186.667 & $297.535 \mathrm{C}$ \\
\hline Médias & $476.042 \mathrm{~A}$ & $317.361 \cdot \mathrm{B}$ & 238.542 & 193.333 & \\
\hline
\end{tabular}

ams (Tukey $5 \%)=8.963$

OBS.: Os dados foram transformados em $\sqrt{x+0,5}$, para análise de variância. 
A maior população de plantas conseguida momento da colheita foi 500.000 plantas.ha ${ }^{-1}$, observada em duas parcelas cultivadas no espacamento de $0,20 \mathrm{~m}$ entre 1 inhas de semeadura e semeada em marco e outra em maio. A menor população fol 185.000 plantas.ha ${ }^{-1}$, obtida de uma parcela conduzida no espaçamento de $0,50 \mathrm{~m}$ entre linhas e semeada em junho.

A análise dos valores médios contidos na Tabela 21, permite observar que a população de plantas por hec tare no espaçamento de $0,20 \mathrm{~m}$ entre linhas é superior ao dobro daquela existente no espaçamento de $0,50 \mathrm{~m}$ entre linhas, em todas as épocas de semeadura testadas.

\subsection{Produção de sementes}

Na Tabela 20, encontram-se os valores de $F$ obtidos na anälise de variância dos dados referentes ao rendimento de sementes de tremoço e o respectivo coeficiente de variação. A análise do efeito simples para épocas de semeadura e espaçamentos foram significativos ao nivel de $1 \%$ de probabilidade, enquanto que para a interação épocas de semeadura versus espacamentos, o teste $F$ não foi significativo.

De acorco com os valores médios da produção de sementes ( $\mathrm{kg} \cdot \mathrm{ha}^{-1}$ ) (Tabela 22$)$, a diferença de produção de sementes da primeira época de semeadura para a última, é extraordinária. I medida que se retardou a época de semeadura houve queda no rendimento de sementes.

A maior producão media de sementes foi 2691 $\mathrm{kg} \cdot \mathrm{ha}^{-1}$, conseguida com a semeadura em marco, no espaçamento de $0,20 \mathrm{~m}$ entre linhas, e o menor valor médio de produção foi 
$473 \mathrm{~kg} \cdot \mathrm{ha}^{-1}$, obtido com a semeadura de junho no espaçamento de $0,40 \mathrm{~m}$ entre Iinhas.

Tabela 22. Valores médios da produção de sementes, em kg.ha-1 de tremoço cultivado em diferentes épocas de semeaduxa e espaçamentos, em Bandeirantes-PR, 1985.

\begin{tabular}{lcccccc}
\hline Epccas de & \multicolumn{3}{c}{ Espacamentos entre linhas $(\mathrm{m})$} & Média \\
\cline { 2 - 6 } semeadura & 0,20 & 0.30 & 0,40 & 0,50 & \\
\hline 23.03 .85 & 2.691 & 2.541 & 2.115 & 2.240 & $2.397 \mathrm{a}$ \\
15.04 .85 & 2.252 & 1.769 & 1.679 & 1.435 & $1.784 \mathrm{~b}$ \\
18.05 .85 & 988 & 849 & 692 & 652 & $795 \mathrm{C}$ \\
15.06 .85 & 699 & 586 & 473 & 477 & $559 \mathrm{C}$ \\
\hline Médias & $1.657 \mathrm{~A}$ & $1.436 \mathrm{AB}$ & 1.240 & $\mathrm{~B}$ & $1.201 \mathrm{~B}$ & \\
\hline
\end{tabular}

dms (Tukey 5 \% $)=238$.

As produções de sementes de tremoço obtidas com as semeaduras em março e abril revelam valores bem superiores aqueles conseguidos com as semeaduras de maio e junho, independentemente do espaçamento adotado. A máxima produção obtida foi conseguida com a semeadura em marco e a menor com a semeadura em junho.

Pelos valores médios de produção de sementes obtidos nos diferentes espacamentos testados, observa-se que, um aumento no espaçamento de $0,20 \mathrm{~m}$ para $0,50 \mathrm{~m}$ ocasionou redução na produção total de sementes.

Os valores médios de produção de sementes obti. dos no espaçamento de $0,20 \mathrm{~m}$ e $0,30 \mathrm{~m}$ foram superiores aqueles a $0,40 \mathrm{~m}$ e $0,50 \mathrm{~m}$ em todas as épocas estudadas. 
Tabela 23. Valores médios das populações de plantas de tremoço por hecta re, apra épocas de semeadura, espaçamentos de semeadura, epocas de corte, em Pandeirantes-PR, 1985.

\begin{tabular}{|c|c|c|c|c|c|c|}
\hline \multirow{2}{*}{$\begin{array}{l}\text { Epocas de } \\
\text { semeadura }\end{array}$} & \multirow{2}{*}{$\begin{array}{c}\text { Espacamento } \\
\text { entre Iinhas } \\
(\mathrm{m})\end{array}$} & \multirow{2}{*}{$\frac{\text { Epocas de }}{60}$} & \multicolumn{3}{|c|}{ corte (dias após emergéncia) } & \multirow[t]{2}{*}{ Médias } \\
\hline & & & 75 & 90 & 105 & \\
\hline \multirow[t]{5}{*}{23.03 .85} & 0,20 & 487.500 & 479.167 & 500.000 & 491.667 & 489.583 \\
\hline & 0,30 & 319.444 & 319.445 & 327.778 & 325.000 & $322 \cdot 917$ \\
\hline & 0,40 & 243.750 & 243.750 & 243.750 & 245.833 & 244.271 \\
\hline & 0,50 & 196.667 & 198.333 & 200.000 & 196.667 & \multirow[t]{2}{*}{197.917} \\
\hline & Mèdias & 311.840 & 310.174 & 317.882 & 314.792 & \\
\hline \multirow[t]{5}{*}{15.04 .85} & 0,20 & 500.000 & 500.000 & 495.833 & 495.833 & 497.917 \\
\hline & 0,30 & 333.333 & 333.333 & 330.555 & 330.555 & 331.944 \\
\hline & 0,40 & 243.750 & 250.000 & 241.667 & 247.917 & 245.833 \\
\hline & 0,50 & 200.000 & 198.333 & 196.667 & 193.333 & \multirow[t]{2}{*}{197.083} \\
\hline & Mëdias & 319.271 & 320.416 & 316.180 & 316.909 & \\
\hline \multirow[t]{5}{*}{18.05 .85} & 0,20 & 495.833 & 500.000 & 500.000 & 495.833 & 497.917 \\
\hline & 0,30 & 327.778 & 333.333 & 327.778 & 322.222 & 327.778 \\
\hline & 0,40 & 245.833 & 245.833 & 247.917 & 245.833 & 246.354 \\
\hline & 0,50 & 200.000 & 196.667 & 198.333 & 198.333 & \multirow[t]{2}{*}{198.333} \\
\hline & Mëdias & 317.361 & 318.958 & 318.507 & 315.555 & \\
\hline \multirow[t]{5}{*}{15.06 .85} & 0,20 & 491.667 & 479.167 & 479.167 & 487.500 & 484.375 \\
\hline & 0,30 & 325.000 & 316.667 & 313.889 & 319.445 & 318.750 \\
\hline & 0,40 & 239.583 & 231.250 & 233.333 & 237.500 & 235.417 \\
\hline & 0,50 & 190.000 & 188.333 & 191.667 & 193.333 & \multirow[t]{2}{*}{190.833} \\
\hline & Mëdias & 311.562 & 303.854 & 304.514 & 309.444 & \\
\hline Mëdias & & 315.008 & 313.350 & 314.271 & 314.175 & \\
\hline
\end{tabular}


Tabela 24. Valores médios da produção de massa verde, em $\mathrm{kg}^{-\mathrm{ha}^{-1}}$, de plantas de tremoço para épocas de semeadura, espaçamentos de semeadura e épocas de corte, em Bandeirantes-PR, 1985.

\begin{tabular}{|c|c|c|c|c|c|c|}
\hline \multirow{2}{*}{$\begin{array}{l}\text { Epocas de } \\
\text { semeadura }\end{array}$} & \multirow{2}{*}{$\begin{array}{c}\text { Espaçamentos } \\
\text { entre linhas } \\
\text { (m) }\end{array}$} & \multicolumn{4}{|c|}{ Epocas de corte (dias após emergência) } & \multirow[t]{2}{*}{ Mëdias } \\
\hline & & 60 & 75 & 90 & 105 & \\
\hline \multirow[t]{5}{*}{23.03 .85} & 0,20 & 18.049 & 27.130 & 39.117 & 40.083 & 31.095 \\
\hline & 0,30 & 15.520 & 22.858 & 35.183 & 42.032 & 28.898 \\
\hline & 0,40 & 11.000 & 16.823 & 29.034 & 29.224 & 21.520 \\
\hline & 0,50 & 8.302 & 14.530 & 24.476 & 28.229 & \multirow[t]{2}{*}{18.884} \\
\hline & Médias & 13.218 & 20.335 & 31.952 & 34.892 & \\
\hline \multirow[t]{5}{*}{15.04 .85} & 0,20 & 22.075 & 32.221 & 35.176 & 29.777 & 29.812 \\
\hline & 0,30 & 17.557 & 27.927 & 27.988 & 24.035 & 24.377 \\
\hline & 0,40 & 14.677 & 23.447 & 26.762 & 25.213 & 22.527 \\
\hline & 0,50 & 11.783 & 20.359 & 23.065 & 20.323 & \multirow[t]{2}{*}{18.882} \\
\hline & Médias & 16.526 & 25.988 & 28.248 & 24.837 & \\
\hline \multirow[t]{5}{*}{18.05 .85} & 0,20 & 15.711 & 17.922 & 18.139 & 11.520 & 15.823 \\
\hline & 0,30 & 12.589 & 15.360 & 15.614 & 8.280 & 12.961 \\
\hline & 0,40 & 9.740 & 12.991 & 14.016 & 8.909 & 11.414 \\
\hline & 0,50 & 7.249 & 11.254 & 13.658 & 9.467 & \multirow[t]{2}{*}{10.407} \\
\hline & Mẻdias & 11.322 & 14.382 & 15.357 & 9.544 & \\
\hline 15.06 .85 & 0,20 & 9.258 & 10.218 & 6.627 & 2.266 & 7.092 \\
\hline & 0,30 & 7.264 & 7.604 & 5.327 & 1.638 & 5.458 \\
\hline & 0,40 & 6.021 & 6.559 & 4.668 & 1.275 & 4.631 \\
\hline & 0,50 & 4.847 & 6.560 & 4.786 & 1.349 & \multirow[t]{2}{*}{4.385} \\
\hline & Mëdias & 6.847 & 7.735 & 5.352 & 1.632 & \\
\hline Médias & & 11.978 & 17.110 & 20.227 & 17.726 & \\
\hline
\end{tabular}


Tabela 25. Valores médios da produção de matéria seca, em $\mathrm{kg} \cdot \mathrm{ha}^{-1}$, de plantas de tremoço para épocas de semeadura e épocas de corte, em Bandeirantes-PR, 1985.

\begin{tabular}{|c|c|c|c|c|c|c|}
\hline \multirow{2}{*}{$\begin{array}{l}\text { Epocas de } \\
\text { semeadura }\end{array}$} & \multirow{2}{*}{$\begin{array}{c}\text { Espaçamentos } \\
\text { entre linhas } \\
\text { (m) }\end{array}$} & \multirow{2}{*}{$\frac{\text { Epocas de }}{60}$} & \multirow{2}{*}{$\frac{\text { corte (dias }}{75}$} & \multirow{2}{*}{$\frac{3 \text { após }}{90}$} & \multirow{2}{*}{$\frac{\text { emergencia) }}{105}$} & \multirow[t]{2}{*}{ Médias } \\
\hline & & & & & & \\
\hline \multirow{5}{*}{23.03 .85} & 0,20 & 2.272 & 4.287 & 6.148 & 7.970 & 5.283 \\
\hline & 0,30 & 2.167 & 3.614 & 5.337 & 7.855 & 4.743 \\
\hline & 0,40 & 1.679 & 2.604 & 4.547 & 5.539 & 3.592 \\
\hline & 0,50 & 1.265 & 2.227 & 3.573 & 5.189 & \multirow[t]{2}{*}{3.064} \\
\hline & Médias & 1.959 & 3.183 & 4.901 & 6.638 & \\
\hline \multirow[t]{5}{*}{15.04 .85} & 0,20 & 3.142 & 5.405 & 6.777 & 7.176 & 5.625 \\
\hline & 0,30 & 2.528 & 4.644 & 5.544 & 5.280 & 4.499 \\
\hline & 0,40 & 2.176 & 3.974 & 4.889 & 4.981 & 4.005 \\
\hline & 0,50 & 1.743 & 3.266 & 4.299 & 4.185 & \multirow[t]{2}{*}{3.373} \\
\hline & Médias & 2.397 & 4.322 & 5.377 & 5.405 & \\
\hline \multirow[t]{5}{*}{18.05 .85} & 0,20 & 3.263 & 3.582 & 3.809 & 3.110 & 3.441 \\
\hline & 0,30 & 2.440 & 2.856 & 3.265 & 2.396 & 2.739 \\
\hline & 0,40 & 2.000 & 2.392 & 2.844 & 2.130 & 2.342 \\
\hline & 0,50 & 1.437 & 1.946 & 2.583 & 2.259 & \multirow[t]{2}{*}{2.056} \\
\hline & Médias & 2.285 & 2.694 & 3.125 & 2.474 & \\
\hline \multirow[t]{5}{*}{15.06 .85} & 0,20 & 2.022 & 2.081 & 1.711 & 2.078 & 1.973 \\
\hline & 0,30 & 1.529 & 1.612 & 1.601 & 1.443 & 1.546 \\
\hline & 0,40 & 1.256 & 1.273 & 1.209 & 1.158 & 1.224 \\
\hline & 0,50 & 1.007 & 1.218 & 1.194 & 1.236 & \multirow[t]{2}{*}{1.164} \\
\hline & Médias & 1.453 & 1.546 & 1.429 & 1.479 & \\
\hline Médias & & 2.023 & 2.936 & 3.708 & 3.999 & \\
\hline
\end{tabular}




\section{DISCUSSÃO}

\subsection{Desenvolvimento das plantas}

o crescimento e o desenvolvimento das plantas de L. albus, através da população estudada no campo, revelaram ser muito variáveis de planta para planta, indicando uma possivel ampla base genética, onde provavelmente métodos de seleção específicos não foram aplicados àquela população.

\subsubsection{Altura de plantas até a gema apical ou base da inflorescēncia principal}

As diferentes épocas de semeadura: $23.03 ; 15$. $04 ; 18.05$ e 15.06 influenciaram a altura até a gema apical ou base da inflorescéncia principal. observou-se que as avaliacões aos 15 e 30 dias revelaram que as semeaduras de marco e abril proporcionaram maior desenvolvimento para as plantas em relação à maio e junho, provavelmente pela maior disponibilidade de água e maior temperatura ocorrida na época (Tabela 1). Aos 45 dias os valores revelaram que, as plantas com semeadura em maio tiveram uma velocidade maior de crescimento, praticamente igualando sua altura àquelas de março e abril, entretanto, as de junho permaneceram com vaIor bem abaixo. A partir dos 60 dias de idade, observou-se que, o valor desse parāmetro para as plantas de março, abril 
e maio não são tão discrepantes, porém, os valores encontrados nas plantas de junho foram bem menores; provavelmente o fator àgua tenha sido o principal responsavel por essa diminuição no crescimento. Concordando com os resultados indicados por MORA (1980) que afirmou haver redução no desenvolvimento da planta por falta de água.

Quanto aos espaçamentos entre Iinhas testados: $0,20 \mathrm{~m} ; 0,30 \mathrm{~m} ; 0,40 \mathrm{~m}$ e $0,50 \mathrm{~m}$, observa-se que inicial mente não influenciaram a altura das plantas, uma vez que, estas são pequenas e não competem por espaço. Entretanto, após 45,60 e 75 dias, observaram os maiores valores absolutos para altura, nos menores espaçamentos entre Iinhas, embora não tenham se apresentado estatisticamente diferentes.

Aos 90 e 105 dias houve diferença estatistica entre os valores encontrados, confirmando, assim, com maior clareza, que o acréscimo na densidade populacional resulta em um maior aumento na altura das plantas.

\subsubsection{Altura total}

De acordo com os resultados obtidos para altura total de plantas, observou-se que tanto a época de semeadura quanto o espaçamento entre linhas influenciaram a altura de plantas.

Aos 15 dias não se observou a influēncia da época de semeadura sobre os valores médios de altura total. de plantas, entretanto, a partir da avaliação aos 30 dias torna-se clara essa influência. As semeaduras de março e abril proporcionaram plantas maiores em relação às semeadas em maio e junho; sendo que, as semeadas em junho apresenta- 
ram valores bem menores que as semeadas em outras épocas.

Revelam os dados, que, o atraso na época de semeadura proporcionou um menor desenvolvimento na altura $f$ nal da planta, acreditando-se que este fato esteja associado à menor disponibilidade hírica (Tabela 1).

Considerando-se as máximas alturas médias obtidas, nas duas últimas avaliações (na faixa de 0,90 a 1,00 m), valores estes compativeis com a altura de plantas citadas por MORA (1980), DERPSCH \& CALEGARI (1985). Entretanto, valores descritos para altura de plantas de tremoço feitos por CORREA (1939), KIEHL (1949), ELOSS (1980), encontram-se com um valor máximo de $1,80 \mathrm{~m}$, bem acima do máximo valor médio obtido em nosso trabalho.

Os valores apresentados pelos diferentes autores, para altura de plantas de tremoço, provavelmente foram obtidos no dossel da população de plantas, visto que estes trabalhos não descrevem a metodologia de avaliação usada. Os valores médios para altura total de plantas revelam que a maior média obtida foi de $0,94 \mathrm{~m}$, em plantas cultivadas no espaçamento de $0,30 \mathrm{~m}$ entre linhas e semeadura em abril. A menor média das plantas foi $0,29 \mathrm{~m}$ cultivada no es pacamento de $0,40 \mathrm{~m}$ e semeadas em junho (Tabela 7).

DERPSCH \& CALEGARI (1985) informaram que na floração plena do tremoço, entre 120 e 140 dias, as plantas normalmente atingem uma altura de 0,80 a $1,50 \mathrm{~m}$, entretanto, os autores não ressaltaram que esta situação é grandemente influenciada pela época de semeadura; obviamente por condições climáticas.

A influēncia do espaçamento entre linhas de 
semeadura sobre a altura total da planta existiu, porém, fol bem menor que a influência da época de semeadura (Tabela 6 ). observou-se de maneira geral, considerando-se as avaliacoes a partir dos 60 dias que, nos menores espacamentos entre 11 nhas apareceram os maiores valores para altura, revelando que, o aumento na densidade populacional provocou aumento no valor da altura de planta, devido provavelmente pela maior competição por luz.

O parāmetro altura total, distāncia entre a superficie do solo e o patamar das folhas mais altas, foi adotado como medida de segurança, uma vez que a variabilidade entre plantas era muito grande. A observação das Tabelas 5 e 7 mostra que os resultados obtidos com esse parâmetrosão mais consistentes do que aqueles obtidos com a altura ate a gema apical. Os trabalhos, encontrados na literatura, sobre altura de plantas não especificam a metodologia utilizada. No entanto, a se julgar pelos valores citados, de até 1,65 $\mathrm{m}$, provavelmente consideraram a altura total.

\subsubsection{Diámetro do caule}

Os valores encontrados para diâmetro do cauIe, aos 15 dias, não revelaram discrepāncia acentuada, embora tenha ocorrido diferença significativa para os valores mé dios, em relação às diferentes épocas de semeadura. provavelmente, a pequena variação existente esteja ligada a condições climáticas, visto que, em relação aos espaçamentos testados não foi significativo, sendo coerente, uma vez que, aos 15 dias não se verificou nenhuma competição estabelecida entre as plantas.

Aos 30 e 45 dias, os valores médios para dià- 
metro do caule foram menos influenciados pelo espaçamento do que pela época de semeadura, sendo que, as semeaduras tardias proporcionaram plantas com diâmetro de caule menor.

A partir dos 60 dias é que se observa com clareza a influência do espaçamento de semeadura sobre o diâmetro do caule, quando nos menores espaçamentos entre linhas são observados os menores valores para diâmetro, indicando uma possivel competição das plantas em altas densidades populacionais, sendo confirmada pela maior altura que as plantas alcançaram nos menores espaçamentos (Tabela 8).

Em relação às épocas de semeadura, as avaliações a partir dos 60 dias revelam, com clareza, que um retar damento na época de semeadura resultou em menor valor médio do diâmetro do caule. Este fato pode ser explicado pelas meIhores condições climáticas, principalmente pela maior precipitaçăo no início do periodo (Tabela 1), favorecendo o desenvolvimento das plantas, estando de acordo com os resultados obtidos para altura das plantas (Tabela 8), onde observa - se comportamento semelhante.

A bibliografia consultada não faz qualquer referência sobre diâmetro do caule do tremoço, no entanto os resultados aqui obtidos não contrariam o que ocorre com os demais adubos verdes: o diāmetro do caule aumenta com a diminuição da população.

\subsection{Produção de massa verde}

\subsubsection{Epoca de semeadura}

Os maiores rendimentos de massa verde de tre- 
moco foram conseguidos com as semeaduras realizadas em marco e abril em relação às de maio e junho (Tabelas 14, 15 e 24), estando coerentes com os trabalhos relatados por

KIEHL (1949), ANONIMO (1962), ANONNIMO (1968), GALETI (1979) e BRAGA \& BULISANI (1986).

Os resultados mostraram ainda que retardando- se a época de semeadura acarretou declínio no rendimento de massa verde (Tabelas 14 e 15), em qualquer espaçamento entre 1inhas adotado. Entretanto, observa-se comportamento semeThante de produtividade nas semeaduras de março e abril, onde, pelos valores médios obtidos não se constatou diferença significativa, o que não ocorreu com as semeaduras de maio e junho, as quais apresentaram rendimentos bem menores, concor dando com trabalho de DERPSCH \& CALEGARI (1985) que indicaram que o plantio antecipado eleva a produção de massa verde do tremoço. Indicação discordante foi apresentada por SABADIN (1984) que recomendou a semeadura do tremoco nos meses de maio e junho quando este se destina à prática da adubação verde.

A queda de rendimetno de massa verde do tremoço provavelmente seja explicada, pelas condições climáticas, especialmente precipitação, visto que, a temperatura mí nima registrada no periodo de março a outubro foi $10,4^{\circ} \mathrm{C}$ o que não limita o desenvolvimento do L. albus, pois

BAER (1973), DERPSCH et alii (1980) e DERPSCH \& CALEGARI (1985) afirmaram que essa espécie resiste até 3 a $4^{\circ} \mathrm{C}$ negativos, en quanto que MORA (1980) e SCHERER (1982) indicaram que suporta até $-6^{\circ} \mathrm{C}$. Quanto à precipitação (Tabela 1) observa-se que, até maio ocorreram chuvas em quantidades satisfatoria, porém, a partir de maio a precipitação foi muito reduzida, provocando menor desenvolvimento da parte aérea, declinando - rendimento de massa verde. Esses resultados concordam com 
ANÔNIMO (1968) que recomendou o plantio do tremoço no més de março para o Estado de São Paulo, visto que, daí em diante a seca prevalece por vários meses, prejudicando o desenvolvi mento da planta.

A possibilidade da semeadura do tremoço no mês de setembro, foi verificada por GRANATO (1925) e CORREA (1939), onde o primeiro autor constatou ser desfavorável, pois devido ao intenso calor ocasionou redução no ciclo vegetativo e no desenvolvimento da parte aérea, produzinao pou ca biomassa, sendo também coerente com os resultados obtidos por BOUNDY et alii (1982).

Como se comprovou, apesar de não haver diferença estatisticamente significativa entre os valores de ren dimento de massa verde de tremoço quando semeado em março ou abril, em valor absoluto o maior renaimento médio foi alcançado com a semeadura de março. Entretanto, observou-se que para essa semeadura ocorreu uma alta incidência de vaquinha (Diabrotica speciosa) logo no inicio do desenvolvimento (fase de plāntula) o que nos levou a aplicação do inseticida SEVIN 85 PM para seu controle. Nas demais épocas de semeadu ra a presença dessa praga foi praticamente nula. Outro aspecto a ser salientado é que a semeadura de março foi realizada com o solo ainda úmido, logo após as chuvas que antecederam o dia 23. Devido às altas temperaturas que ocorreram após essa data, e por ser um solo argiloso, observou-se um ressecamento com um encrostamento na superficie, ocasionando alguns problemas na emergência das plāntulas. Além disso, embora a semeadura tivesse sido realizada no dia 23 de marco, a emergéncia das plàntulas se deu em 01 de abril, tendo seu desenvolvimento, propriamente dito, iniciado em abril. Dessa forma, pelos resultados conseguidos, nas condições que foi conduzido o experimento, o melhor desempenho foi conse- 
guido com semeadura e desenvolvimento inicial das plantas no mês de abril.

\subsubsection{Espaçamento entre linhas}

A produção de massa verde de tremoço aumentou com a redução do espaçamento entre linhas de semeadura. As maiores produtividades foram obtidas no espaçamento de 0,20 $\mathrm{m}$ e as menores no espaçamento de $0,50 \mathrm{~m}$ (Tabelas 14,16 e 24). Isto provavelmente se deve ao fato de que, a densidade populacional aumentou com a redução do espaçamento, pois no espacamento de $0,20 \mathrm{~m}$ a densidade média populacional foi superior ao dobro daquela existente no espaçamento de $0,50 \mathrm{~m}$ (Tabelas 11,13 e 23). Esses valores concordam com a indica ção de espaçamento de plantio proposta por IGUE et alij (1984) e DERPSCH \& CALEGARI (1985).

Por outro lado, esses resultados discordam da indicação proposta para espaçamento entre linhas de semeadura para tremoço destinado a adubação verde, por ANONIMO (1925) que recomendou espaçamento de 0,60 m entre linhas; por MUZILLI et alii (1983) os quais utilizaram espacamento entre linhas de $0,50 \mathrm{~m} \mathrm{com} 5$ a 7 plantas por metro linear; MIYASAKA (1984) que indicou espaçamento entre linhas de 0,50 m com gasto de $36 \mathrm{~kg} \cdot \mathrm{ha}^{-1}$ de sementes; por UFER (1956) que recomendou $0,40 \mathrm{~m}$ a $0,50 \mathrm{~m}$ entre linhas com 10 sementes por metro linear e de BRAGA \& BULISANI (1986) que recomendaram espaçamento de $0,50 \mathrm{~m}$ a $0,70 \mathrm{~m}$ entre linhas de semeadura.

Provavelmente altos rendimentos de massa verde pudessem ser obtidos no espaçamento de $0,40 \mathrm{~m}$ entre Iinhas com 20 plantas por metro linear, indicado por LEAL (1970), FLOSS (1980) e SABADIN (1984), uma vez que, essa den- 
sidade populacional seria equivalente àquela obtida a $0,20 \mathrm{~m}$ entre linhas com 10 plantas por metro linear. Porém, apesar de não ter sido testado esse arranjo populacional, possivelmente não fosse conveniente devido a grande competição entre as plantas nas linhas de semeadura, ocasionando uma desfolha prematura, além do fato que, no espaçamento de $0,40 \mathrm{~m}$ ocorre uma maior demora e menor eficiéncia na cobertura das entre Iinhas, com menor proteção do solo, o que possibilita o desenvolvimento de invasoras.

Apesar dos maiores rendimentos de massa verde terem sido obtidos no espacamento de $0,20 \mathrm{~m}$ entre linhas de semeadura, observou-se nesse espaçamento que as plantas mostraram-se estioladas, indicando, provavelmente, grande competição entre plantas por espaço, com amarelecimento e queda prematura das folhas inferiores, dando um aspecto morfológico feio à cultura, além do maior gasto em sementes que este plantio exige. Embora a produção de massa verde, no espaçamento de $0,30 \mathrm{~m}$, tenha sido pouco menor àquela obtida no espacamento de $0,20 \mathrm{~m}$, o comportamento das plantas foi meIhor, não sendo observada acentuada competição por espaço e luz, mantendo-se verdes e enfolhadas por maior tempo, com me Ihor aspecto morfológico individual e no conjunto. A recomendação do espaçamento entre linhas de semeadura de $0,30 \mathrm{~m}$ para tremoço destinado a adubação verde é reforçada por CoRREA (1939), ANŌNIMO (1962), GALETI (1979), DERPSCH (1980), MUZILLI et alii (1980) e CURY et alii (1982).

Espaçamentos maiores entre linhas, 0,40 e 0,50 $m$, além de produzirem menor quantidade de massa verde, proporcionaram a ocorrência de plantas daninhas, principalmente no espaçamento de $0,50 \mathrm{~m}$. Esses espaçamentos maiores não produziram uma cobertura efetiva e proteção do solo nas entre linhas, sendo menos interessantes sob o aspecto conserva 
cionista, fato este também observado por DERPSCH (1980).

Para o espaçamento entre linhas de $0,30 \mathrm{~m}, \mathrm{com}$ densidade populacional de 10 plantas por metro linear, admitindo-se uma emergência de $80 \%$ e considerando-se o peso médio de 1.000 sementes igual a 350 e 400 gramas (MUZILLI et alii, 1980), o gasto médio de sementes seria de 146 a 167 $\mathrm{kg} \cdot \mathrm{ha}^{-1}$, concordando com as recomendações propostas por coRREA (1939) e TOMASINI et alii (1982), e discordando parcialmente de BAER (1982) que recomendou taxa de semeadura de 160 $\mathrm{kg} \cdot \mathrm{ha}^{-1}$ somente para semeadura tardia e na época normal indicou 100 a $120 \mathrm{~kg} \cdot \mathrm{ha}^{-1}$.

Entretanto, LESS (1978) indicou que para 0 agricultor garantir um bom rendimento deve cultivar o tremoço no espaçamento de $0,18 \mathrm{~m}$ com densidade de 60 plantas por $\mathrm{m}^{2}$.

\subsubsection{Epocas de corte}

Além da época de semeadura e densidade populacional, o momento de corte do material é muito importante para se maximizar a produção de massa verde de tremoço.

o aparecimento de flores nas plantas de tremoço apresentou uma grande variação de planta para planta. Observou-se planta iniciando seu florescimento entre 30 a 35 dias após emergência, enquanto outros iniciaram por volta dos 60 dias. Estes resultados concordam parcialmente com DERPSCH \& CALEGARI (1985), MUZILLI et alii (1980), que afirmaram que o florescimento se inicia entre 50 a 70 dias após germinação, e discordam de SABADINI (1984) que relatou que o tremoço inicia o florescimento cerca de 90 dias após o plantio. 
Existe um conceito formado de que o corte e a incorporação das plantas destinadas à prática da adubação verde sejam realizados no periodo de florescimento. Entretanto, esse período pode ser muito longo e não define exatamente 0 melhor momento, considerando-se que, dependendo da época de semeadura, nas avaliações realizadas aos 60 e 105 dias, as plantas apresentaram-se com flores. Para as plantas semeadas em marco, as quais encontravam-se em fase de florescimento, as avaliaçóes realizadas aos 60 e 105 dias mostraram um rendimento de massa verde de $13.000 \mathrm{~kg} \cdot \mathrm{ha}^{-1} \mathrm{e}$ $35.000 \mathrm{~kg} . \mathrm{ha}^{-1}$, respectivamente (Tabela 15). Esses resultados mostram uma grande amplitude, revelando que, indicaçós amplas não são adequadas, como as de ANÔNIMO (1925), KIFHL (1949) e GALETI (1979) que recomendaram corte e incorporação do tremoço na florąão. Segundo as recomendações propostas por CORREA (1939) e ANŌNIMO (1962), o corte do tremoço deve ser feito quando $2 / 3$ da lavoura estiver florida, ou seja, cerca de 54 a 60 dias após o plantio, para as condições do Rio Grande do Sul. Fstas propostas discordam dos resultados obtidos, pois nas condições testadas, nessa época, as plantas ainda não haviam atingido seu máximo potencial produtivo de biomassa, principalmente nos plantios antecipados.

Indicações propostas por LFAL (1970) e FLOSS (1980) para se proceder o corte e enterrio do tremoço no aparecimetno da primeira camada de flores, que nas condições do Rio Grande do Sul ocorre aos 90 dias, são também inadequa dos e contrastantes com os resultados obtidos, uma vez que, dependendo da época de semeadura e condições ambientes, essa fase ocorre por volta dos 50 dias.

O florescimento e o número de floradas na lavoura do tremoço é dependente da época de semeadura e condições ambientes. observou-se para o plantio de março, que 
a maioria das plantas apresentaram até trés floradas, enquan to que, aquelas semeadas em junho normalmente apresentaram somente uma, concordando com DERPSCH \& CALEGARI (1985), porém discordando de CORREA (1939) que informou que nas condicooes do Rio Grande do sul o tremoço passa por quatro floradas.

Com o plantio de março, observou-se uma produção crescente de massa verde até os 105 dias, quando as plantas apresentavam-se bem enfolhadas e com forte vigor vegetativo; isto se deve em parte, ao fato das condições climáticas, principalmente precipitação, com melhor distribuicão no período (Tabela 1 ).

Para as semeaduras de abril e maio observou- se que a máxima produção foi obtida aos 90 dias após emergência, revelando que, nessa data seria o melhor momento para o seu corte. O encurtamento do ciclo foi verificado, sendo, provavelmente, devido ao retardamento na época de semeadura, principalmente em função da deficiencia hídrica, verificada no período, e pelo aumento da temperatura.

Para a semeadura de junho o teto máximo para produção de massa verde foi conseguido aos 75 dias, sendo o rendimento de biomassa bem inferior, quando comparado aos de mais rendimentos obtidos nas demais épocas de semeadura. Fsse fato pode ser explicado pelas condições climáticas que ocorreram no periodo, uma vez que a elevação de temperatura provoca o encurtamento do ciclo do tremoço, concordando com as observações de CORRFA (1939), e também a falta de água levou à reducão no desenvolvimento vegetativo, diminuindo a produção de biomassa.

Para o plantio realizado em junho, a máxima 
producão de biomassa fol alcançada aos 75 dias, sendo que, no período de 120 a 140 dias, as plantas apresentavam-se completamente secas, prontas para a colheita de sementes. Este fato discorda da recomendação feita por DERPSCH \& CALEGARI (1985) para se proceder o corte do tremoco entre 120 e 140 dias e das indicaçōes de IGUE et alii (1984) para se cortar as plantas na floração plena, aos 120 dias. De acordo com os resultados obtidos concluiu-se que estas recomendaçóes são demasiadamente tardias, uma vez que dependendo das condiçoes ambientes e da época de semeadura, a máxima produção de massa verde é atingida anteriormente (Tabela 16).

De forma geral, para plantios antecipados, sob condições climáticas favoráveis, a indicação do corte do material entre 90 e 100 dias após emergência, parece mais adequado; entretanto a indicação do momento do corte das plantas de tremoço não deve estar condicionada somente à idade cronológica, mas também a algum aspecto morfológico que permita a fácil identificação pelo agricultor para se atingir melhores resultados na prática da adubação verde. Dessa forma, embora não se tenha caracterizado as fases da planta, observou-se que um bom momento para o corte seria aquele onde as, primeiras vagens formadas, oriundas da inflorescência principal, estivessem em média com 4 a $5 \mathrm{~cm}$ de comprimento, sendo que, nessas condições, a cultura estaria entre a segunda e terceira florescéncia, ou entre a segunda florescência e emissão dos ramos terciários. Nesta fase não haveria formação de sementes viáveis, nem desbalanceamento de nutrientes na planta pela migração dos elementos para a formação de vagens e enchimento dos grãos, o que concorda com DERPSCH \& CALEGARI (1985).

Para as semeaduras tardias, sob condiçōes climáticas menos favoráveis, principalmente deficiēncia hi- 
híarica, a indicação do corte do material entre 70 e 80 dias após emergéncia parece mais adequada (Tabela 15), pois sob estas condicões as plantas encurtam seu ciclo. Nesta situação a lém da idade cronológica, uma característica morfológica para orientação seria quando as prímeiras vagens da _ inflorescéncia principal estivessem com 4 a $5 \mathrm{~cm}$ de comprimento, sendo que, a lavoura poderia apresentar-se florescida ou já passada dessa fase.

Com os resultados obtidos, para efeito de dimensionamento de rendimento de massa verde de tremoco usado na adubação verde no Estado do paraná, podemos classificar a produção em baixa quando inferior a $15.000 \mathrm{~kg} \cdot \mathrm{ha}^{-1}$, em média quando de 15.000 a $30.000 \mathrm{~kg} \cdot \mathrm{ha}^{-1}$ e em alta produção aquelas Iavouras que ultrapassarem a $30.000 \mathrm{~kg} \cdot \mathrm{ha}^{-1}$ de massa verde. Essas faixas de rendimento diferem daquelas propostas por Lemmermann (1901), citado por KIEHL (1949), que classificou a produção pequena quando inferior a $8.000 \mathrm{~kg}^{-\mathrm{ha}^{-1}} \mathrm{de}$ massa verde; $22.000 \mathrm{~kg} \cdot \mathrm{ha}^{-1}$ em média e $36.000 \mathrm{~kg} \cdot \mathrm{ha}^{-1}$, grande.

As Figuras 1, 2, 3 e 4 ilustram os resultados obtidos e discutidos.

\subsection{Produção de matéria seca}

Conforme se constatou, a produção de matéria seca de tremoço foi variável em função da época de semeadura, espaçamento e do momento de corte das plantas, sendo o maior rendimento $7.970 \mathrm{~kg} \cdot \mathrm{ha}^{-1}$, obtido de parcelas semeadas em março, no espaçamento de $0,20 \mathrm{~m}$ entre linhas, com o corte das plantas aos 105 dias. A menor produtividade foi 1.007 $\mathrm{kg} \cdot \mathrm{ha}^{-1}$ obtida de parcelas semeadas em junho, no espaçamento de $0,50 \mathrm{~m}$ entre linhas com o corte das plantas aos 60 dias 
(Tabela 25$)$.

\subsubsection{Foca de semeadura}

Os valores médios obtidos para a produtividade de matéria seca de tremoco foram semelhantes para as semeaduras de março e abril, não sendo constatada diferença estatistica, pelo teste de Tukey, à $5 \%$ de probabilidade. Entretanto, observou-se que, em valor absoluto a maior média fol obtida com a semeadura de abril. os menores valores foram obtidos com a semeadura de junho, sendo bem inferiores aqueles obtidos com a semeadura, de marco e abril (Tabela 17).

Verificou-se que retardando-se a época de semeadura acarretou um gradual declinio no rendimento de matéria seca, onde comparando-se a produtividade de $4.375 \mathrm{~kg} \cdot \mathrm{ha}^{-1}$ ob tidos com a semeadura em abril com $1.477 \mathrm{~kg} \cdot \mathrm{ha}^{-1}$, obtidos na semeadura de junho, constata-se uma redução média de $362 \mathrm{~kg}$. $\mathrm{ha}^{-1}$ para cada semana de atraso na época de semeadura. Concordando com os resultados obtidos por FARRINGTON (1974) e BOUNDY et alii (1982).

Os maiores rendimentos médios de matéria seca de tremoco foram obtidos com as semeaduras de março e abril, concordando com os resultados obtidos para massa verde, sendo provavelmente devido às condições climáticas, principalmente pela pequena quantidade de chuvas verificadas após o mês de maio, ocasionando redução na produção de biomassa das plantas. Este fato pode também ser confirmado pela menor al tura de plantas obtidas com as semeaduras de maio e junho. 


\subsubsection{Espaçamentos entre linhas}

Os dados revelaram que houve diferença significativa pelo teste de Tukey a $5 \%$ de probabilidade para os valores médios de matéria seca de tremoço obtidos nos diferentes espaçamentos testados.

o maior rendimento médio foi obtido no espaçamento entre linhas de $0,20 \mathrm{~m}$. O menor rendimento foi observado no espaçamento de $0,50 \mathrm{~m}, 0$ qual não diferiu estatisticamente do rendimento obtido no espaçamento de $0,40 \mathrm{~m}$ (Tabela 17).

A redução do espaçamento entre linhas de semeadura resultou no acréscimo de rendimento de matéria seca, - que pode ser explicado pela maior densidade populacional encontrada nos menores espaçamentos, pois a população de plantas existentes no espaçamento de 0,20 foi superior ao dobro da população encontrada no espaçamento de $0,50 \mathrm{~m}$ (Tabelas 11 e 13 ), concordando com os resultados obtidos por IVANOV (1975).

\subsubsection{Epoca de corte}

A produtividade de matéria seca foi variável em função da idade das plantas (Tabelas 18 e 19 ).

Observou-se que para as semeaduras de março e abril o acúmulo de matéria seca foi crescente, expressando máximo valor no corte das plantas aos 105 dias. Para a semeadura de maio o máximo acúmulo de matéria seca ocorreu aos 90 dias. Enquanto que para a semeadura de junho, mesmo não havendo diferença estatistica entre os valores obtidos nas 
diferentes épocas de corte, o valor máximo para matéria seca foi obtido aos 75 dias (Tabela 18 ).

Considerando-se um comportamento semelhante para o rendimento médio de matéria seca, com as semeaduras de março e abril, uma vez que não se constatou diferença sig nificativa ao nivel de $5 \%$ de probabilidade, observa-se que as semeaduras de maio e junho apresentaram declínio no rendimento, quando o atraso na poca de semeadura acarretou menor acúmulo de matéria seca nas plantas. Este fato pode ser parcialmente explicado devido às condições ambientes que ocorreram no período de março a outubro, principalmente pela baixa precipitação.

Para a semeadura de março a abril as condicões de temperatura e precipitação (Tabela 1) foram favoráveis, quando as plantas apresentaram ótimo comportamento morfológico, mantendo-se enfolhadas e vigorosas até a última avaliação, aos 105 dias. Para a semeadura de maio, as condi ções de precipitação a partir de junho, foram desfavoráveis, e o déficit híarico ocasionou redução no ciclo vegetativo, constatando-se o máximo acúmulo de matéria seca aos 90 dias, sendo que na avaliaça aos 105 dias as plantas apresentavam um certo grau de amarelecimento, com desfolha na parte inferior. Para a semeadura de junho essa situação foi agravada pelo estresse hidrico sofrido pela planta e pela elevaça na temperatura, que ocorreu a partir de julho, ocasionando redução no ciclo da planta, sendo constatado o máximo acúmulo de matéria seca aos 75 dias, e a avaliação aos 105 dias revelou plantas bastante amarelecidas, com alto grau de desfo1ha. Sendo esse comportamento confirmado pela menor produção de massa verde (Tabelas 15 e 16) e pela menor altura média que as plantas atingiram (Tabela 6). 
Os maiores rendimentos conseguidos para matéria seca de tremoço, variaram de $7000 \mathrm{~kg} \cdot \mathrm{ha}^{-1}$ a $8000 \mathrm{~kg}$. $\mathrm{ha}^{-1}$, correspondendo à cerca de 30.000 a $40.000 \mathrm{~kg} \cdot \mathrm{ha}^{-1}$ de massa verde, e os menores rendimentos cerca de $1.000 \mathrm{~kg} \cdot \mathrm{ha}^{-1}$ de matéria seca, correspondendo em média a $5.000 \mathrm{~kg} \cdot \mathrm{ha}^{-1}$ de massa verde (Tabelas 24 e 25 ). Esses resultados concordam parcialmente com CURY et alii (1982) que revelaram valores médios de matéria seca de $5.000 \mathrm{~kg} \cdot \mathrm{ha}^{-1}$ a $8.000 \mathrm{~kg} \cdot \mathrm{ha}^{-1}$ para rendimentos de $40.000 \mathrm{~kg} \cdot \mathrm{ha}^{-1}$ a $50.000 \mathrm{~kg} \cdot \mathrm{ha}^{-1}$ de massa verde; de IGUE et alii (1984) que mostraram valores variando de $2.000 \mathrm{~kg} \cdot \mathrm{ha}^{-1}$ a $5.000 \mathrm{~kg} \cdot \mathrm{ha}^{-1}$ de matéria seca, correspondentes a $20.000 \mathrm{~kg} \cdot \mathrm{ha}^{-1}$ a $45.000 \mathrm{~kg} \cdot \mathrm{ha}^{-1}$, e de DERPSCH \& CALE-

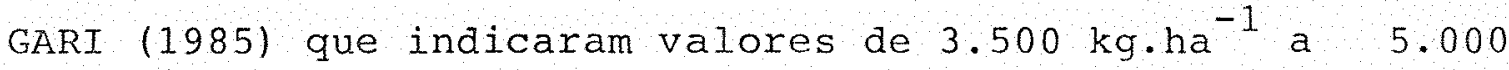
$\mathrm{kg} \cdot \mathrm{ha}^{-1}$ de matéria seca, correspondentes a valores de 30.000 $\mathrm{kg} \cdot \mathrm{ha}^{-1}$ a $40.000 \mathrm{~kg} \cdot \mathrm{ha}^{-1}$ de massa verde.

As Figuras $5,6,7$ e 8 ilustram os resultados obtidos e discutidos.

\subsection{Produção de sementes}

Conforme se constatou, a produção, de sementes de tremoço variou de $2.691 \mathrm{~kg} \cdot \mathrm{ha}^{-1}$ a $473 \mathrm{~kg} \cdot \mathrm{ha}^{-1}$ (Tabela 22), sendo estes rendimentos influenciados pela época de semeadura e espacamento entre fileiras.

\subsubsection{Epocas de semeadura}

os maiores rendimentos de sementes foram obtidos com a semeadura realizada em março e os menores rendimentos com a semeadura de junho, conforme Tabela 22. 
Constatou-se que, retardando-se a época de se meadura houve uma gradual queda de rendimentos em sementes, sendo a semeadura realizada mais cedo a preferencial, concor dando com MASEFIELD (1976), BOUNDY et alii (1982), DERPSCH \& CALEGARI (1985), BRAGA \& BULISANI (1986), porém discordando das indicaçōes propostas por LEAL (1970) e FLOSS (1980) que indicaram, para o Rio Grande do sul, o período de junho e julho para a semeadura do tremoço destinado a produção de sementes e de CURY et alii (1982), que obtiveram os melhores rendimentos de sementes para a semeadura em junho e julho, no Estado do parana.

A queda no rendimento de sementes de tremoço, provavelmente esteve correlacionada com as condicóes climáticas que ocorreram no período, pois, após o mês de maio, as chuvas foram muito reduzidas (Tabela 1), e referéncias feitas por BAER (1973) e DERPSCH \& CALEGARI (1985), apontam necessidade média de pelo menos $500 \mathrm{~mm}$ de chuva entre abril e setembro. Greenwood et alii (1975) citados por SCHERER (1982) afirmaram que as fases mais criticas são os periodos de florescimento e enchimento de grãos, quando altas temperaturas, associadas à baixa disponibilidade de água, acarretam acentuado abortamento de flores, com redução no rendimento de sementes. MORA (1980) afirmou que a deficiência de ăgua no solo, em diferentes intensidades, influe na desfoIha, abortamento de óvulos e abscisão de flores e vagens novas.

Quanto ao fator temperatura, talvez não tenha sido o principal responsāvel pela queda na produtividade de sementes, pois as tempearturas registradas no periodo estão dentro da faixa considerada favorável ao desenvolvimento do tremoco, segundo GLADSTONE (1970), MORA (1980) e DERPSCH et alii (1980). 
Outro aspecto a ser salientado, com relação à época de semeadura, é que no plantio antecipado, observou-se que as plantas passaram por até très florescências, sendo encontradas no final do ciclo, vagens oriundas dessas inflorescéncias, concordando parcialmente com CORREA (1939) e MORA (1980), os quais afirmaram que L. albus passa por até quatro florescências. Entretanto, as semeaduras tardias apresentaram poucas plantas passando por mais de uma flotescêncla, sendo encontradas, raramente, vagens que não fossem oriundas da inflorescência principal. Esse-fato pode ser explicado, em parte, pela afirmação de MORA (1980) que revelou que sob condições de umidade deficiente ocorre concentração da matéria seca na haste principal, não ocorrendo distribuição homogênea para as ramificações laterais.

Nas condicões em que foi desenvolvido o trabalho, a variação média de rendimento, considerando-se todos os espaçamentos testados, fol: $2.397 \mathrm{~kg} \cdot \mathrm{ha}^{-1}$ para $559 \mathrm{~kg}$. $\mathrm{ha}^{-1}$, significando uma reaução de $1838 \mathrm{~kg} \cdot \mathrm{ha}^{-1}$ de sementes. Supondo-se que, no periodo compreendido da primeira à última semeadura ocorreram 11 semanas, observou-se que, para cada semana de atraso na época de semeadura ocorreu uma queda media de rendimento de $167 \mathrm{~kg} \cdot \mathrm{ha}^{-1}$. Este fato concorda parcialmente com os resultados obtidos por WALTON (1982) que encontrou redução semanal de até $300 \mathrm{~kg} \cdot \mathrm{ha}^{-1}$ no rendimento de sementes de tremoço com o retardamento na época de semeadura.

\subsubsection{Espacamento entre linhas}

Conforme se constatou, houve influência do es pacamento entre as linhas de semeadura sobre o rendimento de sementes de tremoço, sendo que a maior produtividade média 
foi conseguida no espaçamento entre linhas de $0,20 \mathrm{~m}$ e a menor no espacamento de $0,50 \mathrm{~m}$ (Tabela 22).

Observou-se que à medida que se aumentou o es paçamento de $0,20 \mathrm{~m}$ para $0,50 \mathrm{~m}$ reduziu-se o rendimento, sendo que, a produtividade média obtida no espaçamento de 0,40 $\mathrm{m} e 0,50 \mathrm{~m}$ não diferiram estatisticamente à $5 \%$, pelo teste de Tukey.

Esse fato pode ser explicado em parte, pelas diferentes densidades populacionais obtidas, pois a população de plantas de tremoço no espaçamento de $0,20 \mathrm{~m}$ entre $11-$ nhas era superior ao dobro daquela existente no espaçamento de $0,50 \mathrm{~m}$ (Tabela 21$)$.

As maiores produtividades de sementes encontra das nos espaçamentos de $0,20 \mathrm{~m}$ e $0,30 \mathrm{~m}$ entre linhas, discordam dos de LEAL (1970) e FLOSS (1980), os quais recomendaram espaçamento de $0,80 \mathrm{~m}$ entre linhas; de MUZILI et alii (1980): entre $0,70 \mathrm{~m}$ e $0,80 \mathrm{~m}$ de espacamento; de sANTos et alii (1984): 0,60 m entre Iinhas e de BRAGA \& BUSILANI (1986) que recomendaram de $0,50 \mathrm{~m}$ a $0,70 \mathrm{~m}$ entre linhas. Referéncias foram feitas por CURY et alii (1982) e DERPSCH \& CALEGARI (1985) recomendando $0,50 \mathrm{~m}$ entre linhas de semeadura para cultivo do tremoço visando a produção de sementes.

Embora as maiores produtividades de sementes tenham sido constatadas nos menores espacamentos entre linhas adotados, observou-se que nessa situação, as plantas de tremoco apresentavam menor rendimento individual, com menor número de vagens por planta e menor tamanho e peso médio das sementes, concordando com trabalhos de WITHERS et alii (1974), GOULDEN (1976), HERBERT (1977) e HERBERT (1979). Contudo, não se avaliou se essas diferenças observadas acar- 
retariam, de alguma forma, prejuizo para a futura lavoura oriunda desse material.

Considerando-se os espaçamentos entre linhas de $0,20 \mathrm{~m} ; 0,30 \mathrm{~m} ; 0,40 \mathrm{~m}$ e $0,50 \mathrm{~m}$, todos com média de 10 plantas por metro linear, obtiveram-se densidades populacionais médias de 50 plantas. $\mathrm{m}^{-2} ; 33$ plantas. $\mathrm{m}^{-2}, 25$ plantas. $\mathrm{m}^{-2}$ e 20 plantas. $\mathrm{m}^{-2}$. Admitindo-se um indice de $80 \%$ de emer gência e o peso médio de 1000 sementes lgual a 363 gramas, segundo MIYASAKA (1983), são necessários, respectivamente, para plantio $227 \mathrm{~kg} \cdot \mathrm{ha}^{-1} ; 151 \mathrm{~kg} \cdot \mathrm{ha}^{-1} ; 113 \mathrm{~kg} \cdot \mathrm{ha}^{-1}$ e $91 \mathrm{~kg}$. $\mathrm{ha}^{-1}$ de sementes.

observa-se que a maior parte da literatura na cional recomenda cerca de $0,50 \mathrm{~m}$ entre linhas e $90-100 \mathrm{~kg}$. $\mathrm{ha}^{-1}$ de sementes, enquanto que os resultados aqui obtidos mos tram um melhor rendimento em sementes para espaçamentos menores e densidade de semeadura maiores $(0,20-0,30 \mathrm{~m}$ entre Iinhas e cerca de $220 \mathrm{~kg} \cdot \mathrm{ha}^{-1}$ de sementes), o que acorda com resultados obtidos na Austrália e na Inglaterra.

Os maiores rendimentos médios obtidos foram com as maiores densidades populacionais, ou seja, ao redor de 50 plantas.m ${ }^{-2}$, concordando com WALTON (1982), que sob con dições favoráveis, obteve as máximas produtividades com densidade populacional ao redor de 45 plantas.m ${ }^{-2} ; e$ parcialmente com HERBERT (1977) que obteve o máximo rendimento de se mentes na maior densidade populacional testada, 35,6 plantas. $\mathrm{m}^{-2}$. Entretanto, MC GIBBON \& WILLIAMS (1980) e BRADLEY (1982) sugeriram como taxa ótima de semeadura para tremoço, na Inglaterra, $\quad 75$ plantas. $\mathrm{m}^{-2}$.

A Figura 9 ilustra os resultados obtidos e discutidos. 


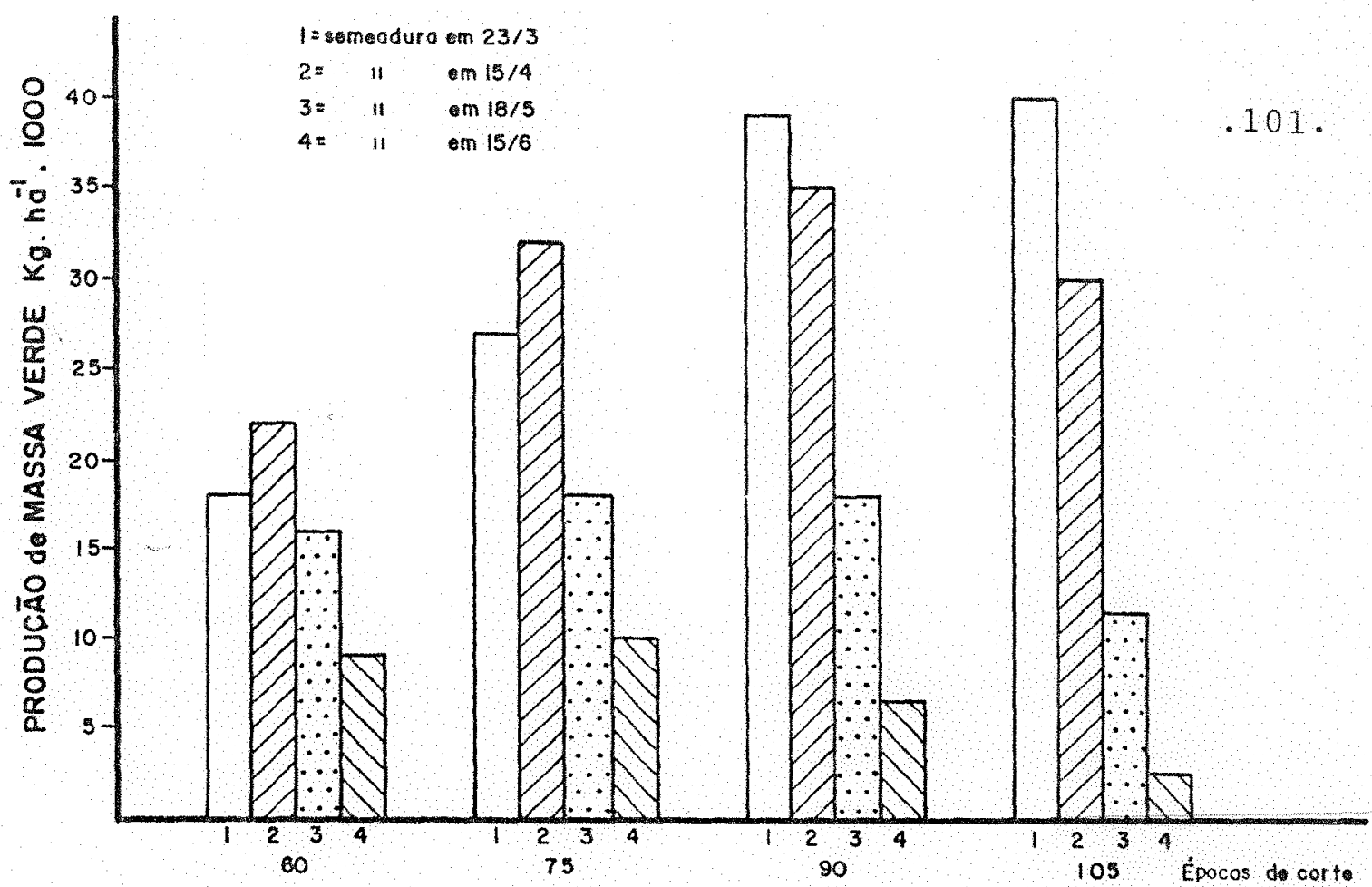

Figura 1. Efeito de épocas de semeadura e momentos de corte sobre a produção de massa verde de tremoço, cultivado no espaçamento de $0,20 \mathrm{~m}$.

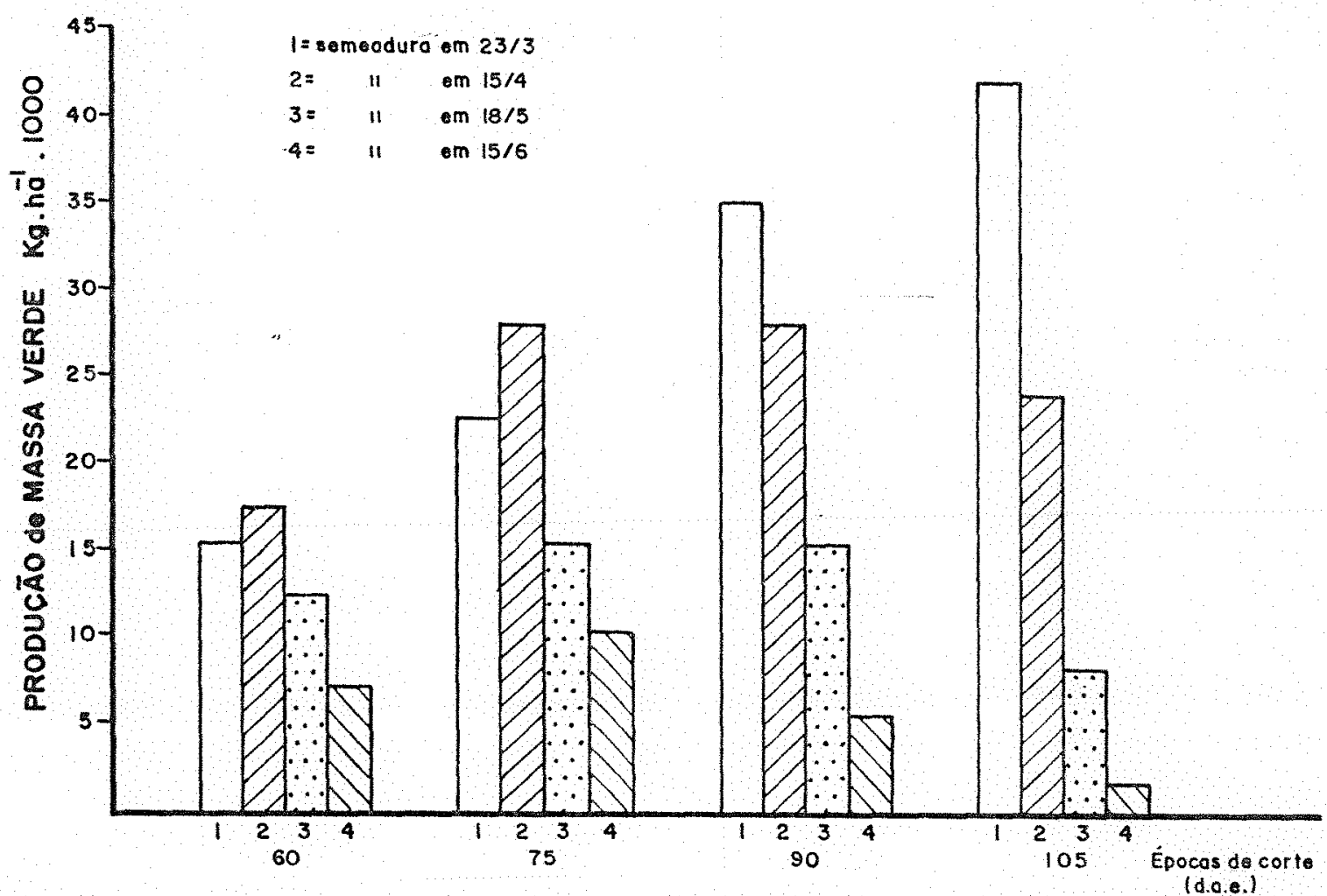

Figura 2. Efeito de épocas de semeadura e momentos de corte sobre a produção de massa verde de tremoço, cultivado no espaçamento de $0,30 \mathrm{~m}$. 


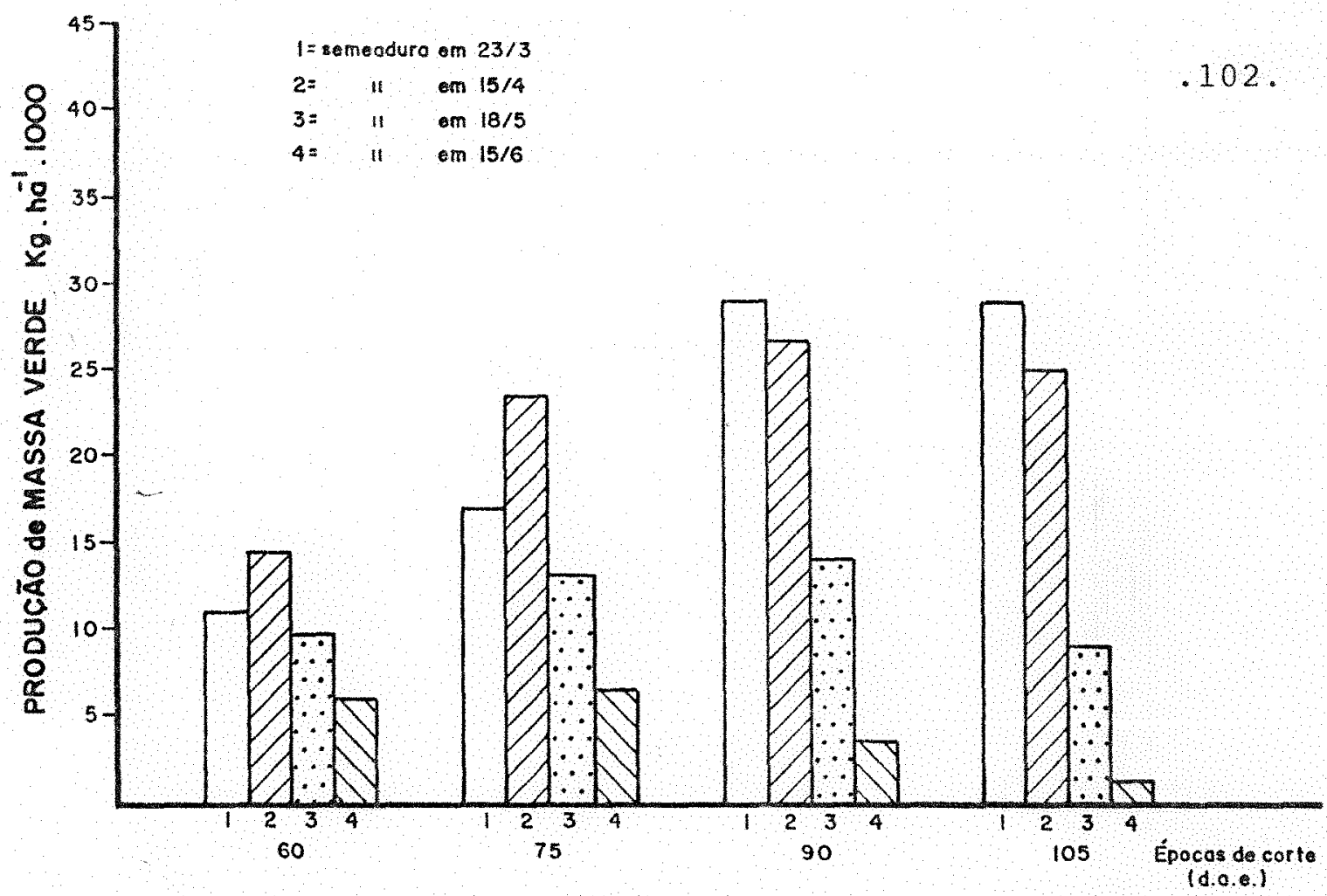

Figura 3. Efeito de épocas de semeadura e momentos de corte sobre a produção de massa verde de tremoço, cultivado no espaçamento de $0,40 \mathrm{~m}$.

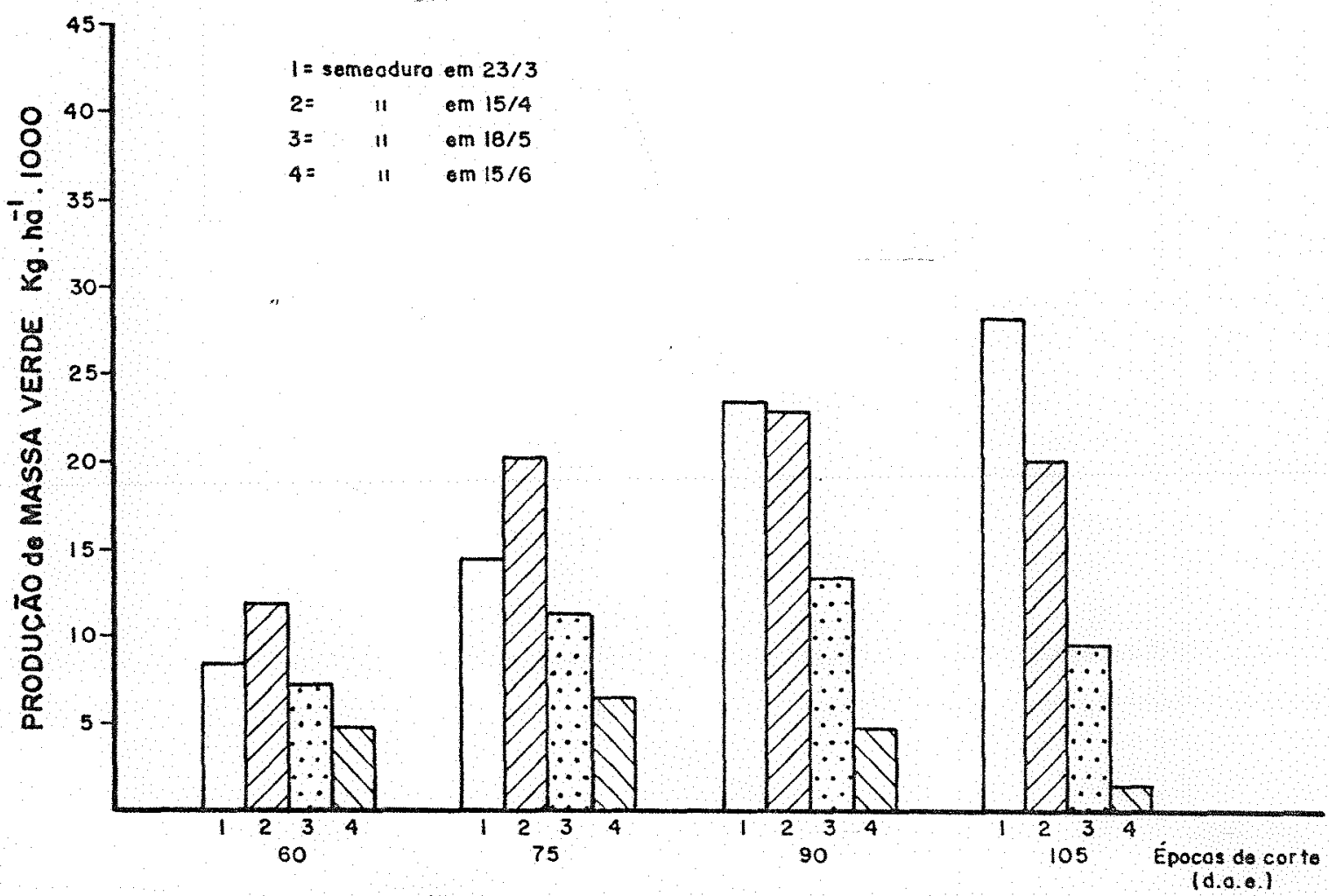

Figura 4. Fifeito de épocas de semeadura e momentos de corte sobre a produção de massa verde de tremoço, cultivado no espacamento de $0,50 \mathrm{~m}$. 




Figura 5. Efeito de épocas de semeadura e momentos de corte sobre a produção de matéria seca de tremoço, culti vado no espaçamento de $0,20 \mathrm{~m}$.

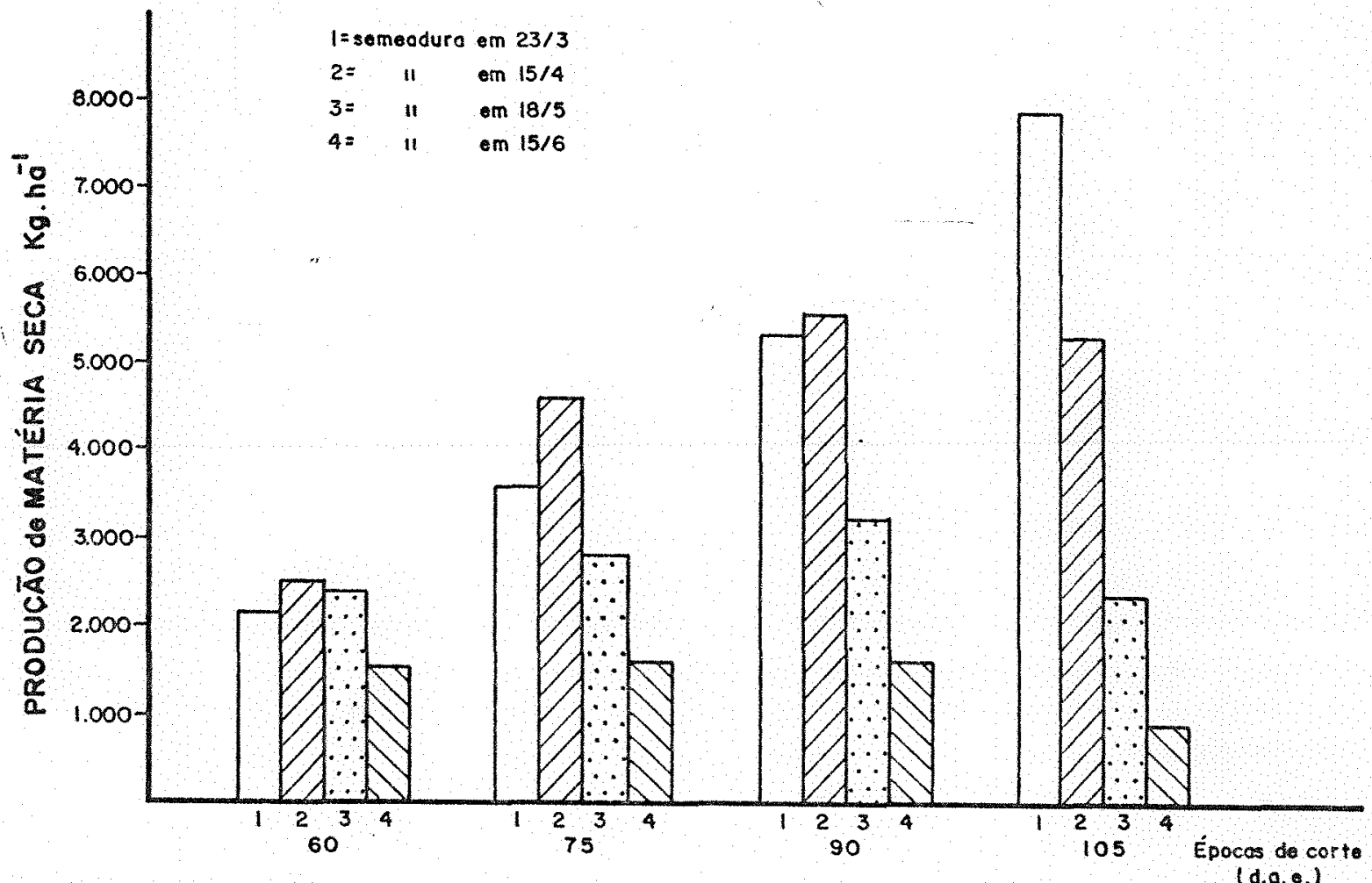

Figura 6. Ffeito de épocas de semeadura e momentos de corte sobre a produção de matéria seca de tremoço, culti vado no espaçamento de $0,30 \mathrm{~m}$. 


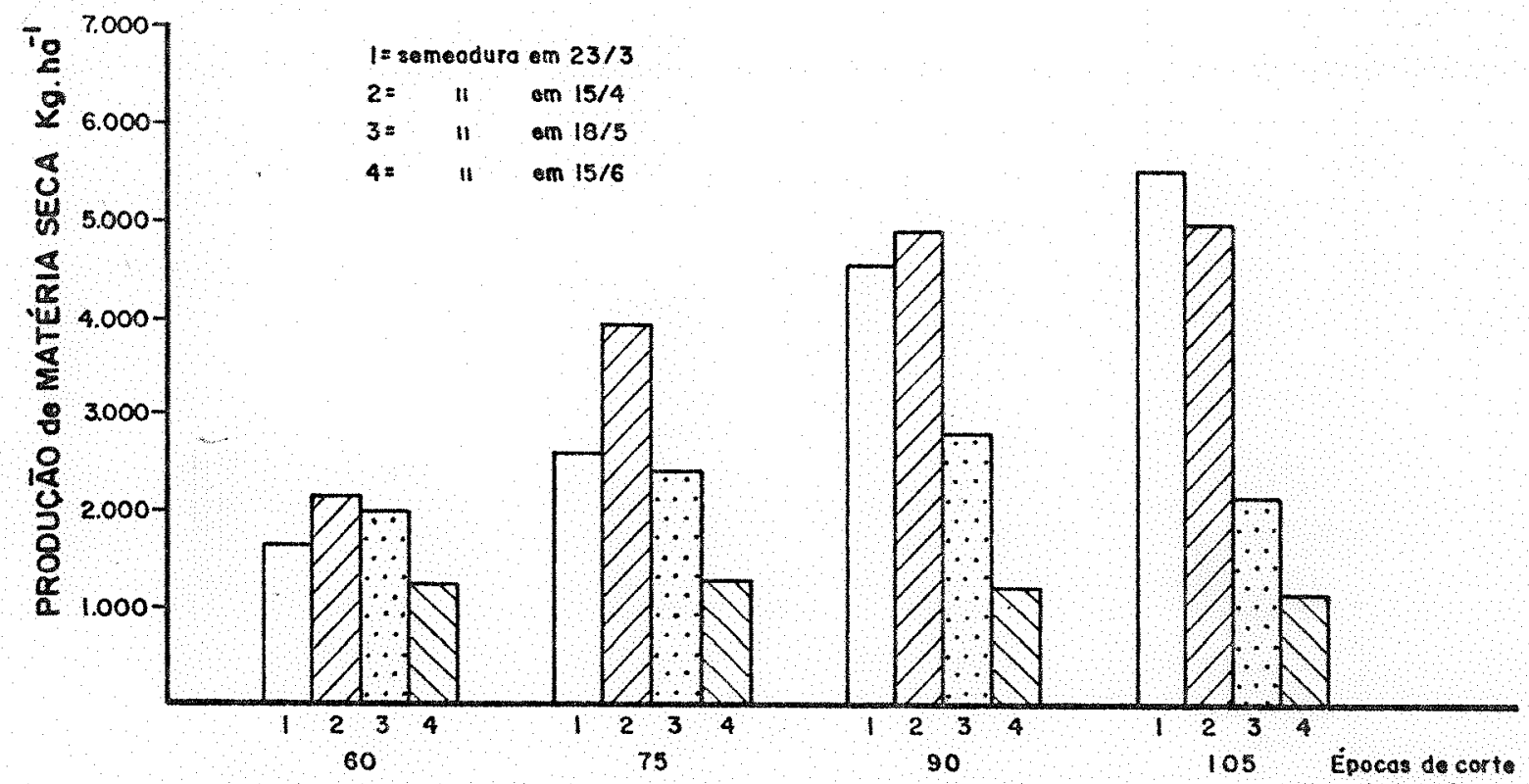

Figura 7. Efeito de épocas de semeadura e momentos de corte sobre a produção de matéria seca de tremoço, cult 1 vado no espaçamento de $0,40 \mathrm{~m}$.

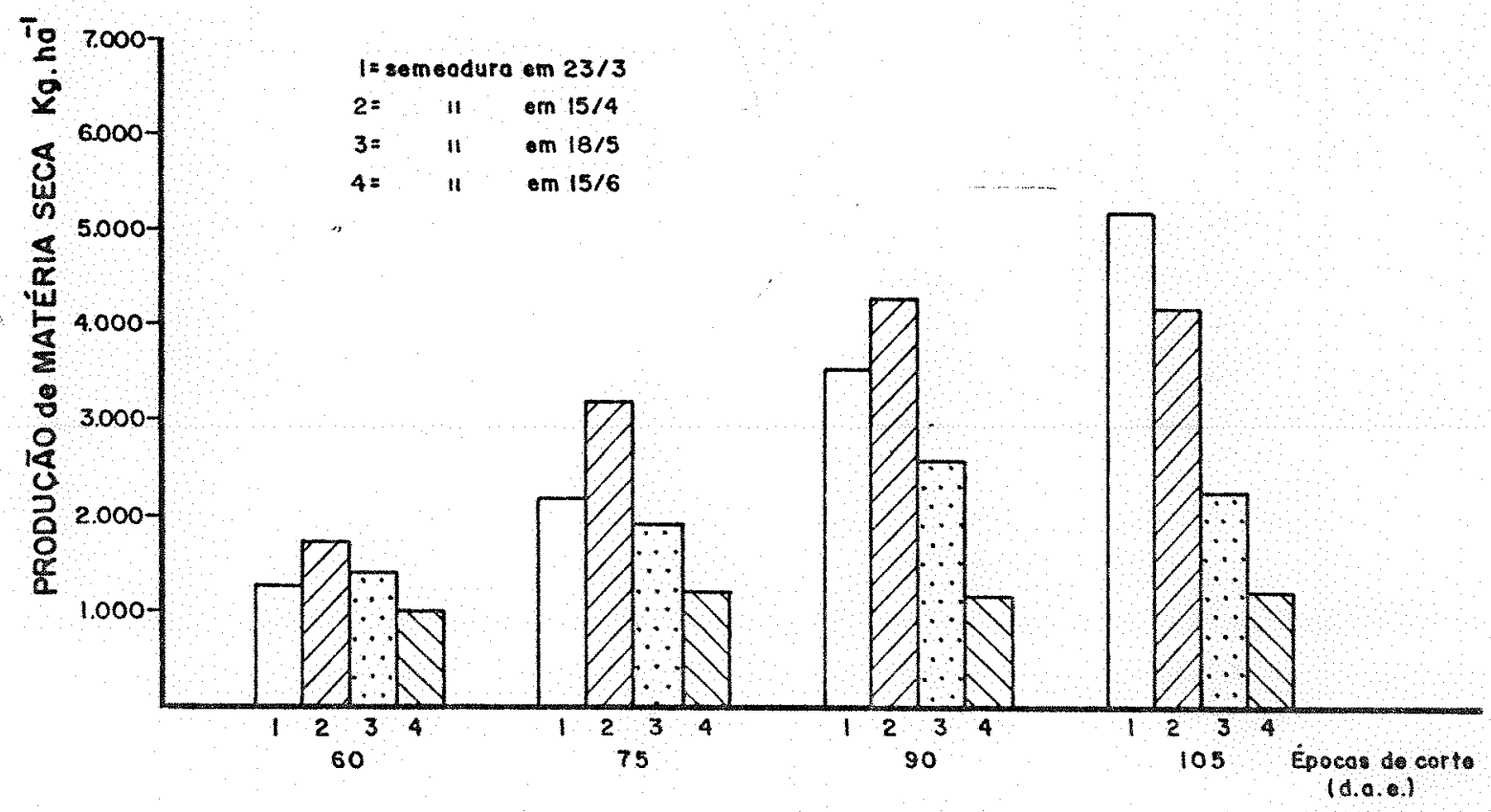

Figura 8. Efeito de épocas de semeadura e momentos de corte sobre a produção de matéria seca de tremoço, culti vado no espaçamento de $0,50 \mathrm{~m}$. 




Figura 9. Efeito de épocas de semeadura e espaçamentos sobre a produção de sementes $\left(\mathrm{kg} \cdot \mathrm{ha}^{-1}\right)$ de tremoço. 


\section{CONCLUSÖES}

A análise e a discussão dos resultados e das condições do presente trabalho permitem as seguintes conclusões:

- A altura das plantas, seja até a gema apical, seja até o patamar das folhas mais altas, é maior para semeaduras em março-abril e para espaçamentos de $0,20-0,30 \mathrm{~m}$ entre linhas. A utilização da altura total (até o patamar das foIhas mais altas) apresenta resultados mais consistentes.

- o diâmetro dos caules é favorecido pelas semeaduras em marco-abril e pelos espaçamentos maiores.

- As produções de massa verde e de matéría seca aumentam com a antecipação da semeadura e com a diminuição do espaçamen to entre linhas. Recomenda-se, pois, para adubação verde, a semeadura em fins de marco-inicio de abril, e espaçamento de $0,30 \mathrm{~m}$ entre linhas.

- Para plantios antecipados é recomendável a realização do corte das plantas aos 100 dias após a emergência, quando as primeiras vagens, provenientes da inflorescência principal, estiverem com 4 a $5 \mathrm{~cm}$ de comprimento, e a lavoura entre a segunda e a terceira florescência, ou entre a segunda florescência e a emissão de ramos secundários. 
- Para plantios retardados e condições climāticas menos favo ráveis recomenda-se o corte das plantas aos 80 dias após a emergência, quando as primeiras vagens, provenientes da inflorescência principal, apresentam 4 a $5 \mathrm{~cm}$ de comprimen to.

- A produção de sementes aumenta com antecipação da semeadura e com a diminuição do espaçamento entre linhas, sendo, pois, recomendável a semeadura em fins de marco-início de abril, com $0,30 \mathrm{~m}$ de espaçamento entre linhas. 


\section{REFERENCIAS BIBLIOGRAFICAS}

ALCOVER, M. Minha opintão sobre o Lupinus como cultura no Parana. Paraná, IAPAR, 1981. 2 p.

ALGUMAS informações sobre o tremoço. FIR, são paulo, 10 : 11,1968 .

ALONSO, J.L.J. Introduccion al cultivo del Lupinus (altramuz). Comunicaciones I.N.I.A. Série produccion vegetal, Madrid, (26): $1-18,1980$.

BAER, E. Von. Estudio sobre la possibilidad de la produccion y utilizacion de Lupinus sp. en Brasil. GORBEA, s. ed., 1973. $7 \mathrm{p}$.

BAER, E. Von. Production of lupines in Chile. In: GRoss, R. \& BUNTING, E.S. ed., Agricultural and nutritional aspects of lupines: proceedings of the First International Iupine Workshop, ESCHBORN, 1982. p. 282-5.

BOUNDY, K.A.; REEVES, T.G.; BROOKE, H.D. Growth and yield studies of Jupinus angustifolius and $L$. albus in Victoria. Australian Journal of Experimental Agriculture an Anima1 Husbandry, Melbourne, 22(114/115): 76-82, 1982. 
BRADLEY, R.S. The effect of sowing date in the development of Lupinus albus in the $U K$, and on its optimum plant density. In: GROSS, R. \& BUNTING, E.S., ed. Agricultural and nutritional aspects of Lupines; proceedings of the First International Lupine Workshop, ESCHBORN, 1982. p. 158-73.

BRAGA, N.R. \& BULISANI, E.A. TremoÇO (Lupinus albus L.). Boletim do Instituto Agronómico, Campinas, (200): 203, 1986.

CORREA, O. Adubos verdes; O tremoço (Lupinus, sp) e sua aplicação no melhoramento das terras. porto Alegre, secretaria de Estado dos Negócios da Agricutlura, Indústria e Comércio, 1939. 50 p. (Boletim, 26).

CURY, B.; ALBERINI, J.L.; CATANEO, A. Efecto del espaciamento y densidad en la produccion de materia verde y granos de altramuz (Lupinus sp.). (Trabalho apresentado na II Conferència Internacional del Lupino, Torremolinos, Má laga, 1982).

DERPSCH, K.; ALBERINI, J.L.; MONDARDO, A.; MURILLI, O. InEormacoes sobre (Lupinus sp.). Informe da Pesquisa, Londrina, 129$): 1-18,1980$.

DERPSCH, R. \& CALEGARI, A. Guia de plantas para adubação verde de inverno. Londrina, IAPAR, 1985. $96 \mathrm{p}$.

D'UTRA, G.R.P. Adubos verdes. São Paulo, Secretaria da Agricultura, Comércio e obras públicas, 1949. 76 p. 
FARRINGTON, 2. Eefect of planting time on growth and seed yield of lupins, peas and vetches on the swan coastal. Plain, Western Australia - Australian Journal of Experimental Agriculture and Animal Husbrandry, Melbourne, $14(69): 539-46,1974$.

FLOSS, E.L. A cultura do tremoço. Lavoura Arrozeira, porto Alegre, $33(323): 46: 50,1980$.

FUNDAC̆̃O INSTITUTO AGRONOOMICO DO PARANA. Relatólo Técnico Anua1 1980. Londrina, IAPAR, 1981. p. 21-130.

GALETI, P.A. Conservação do solo-reflorestamento-clima. 2 . ed. Campinas, Instituto Campineiro de Ensino Agricola, 1979. p. $97-111$.

GLADSTONES, J.S. Lupins in Western Australia. 3. Cultivation methods-continued. Journal of Agriculture of Western Australia, Janah, 477-84, 1969.

GLADSTONES, J.S. Lupins as crop plants: review article. Field Crop Abstract, Aberystwyth, 23(2): 123-48, May, 1970 .

GLADSTONES, J.S. The Meditexranear White Lupin. Journal of Agriculture of Western Australia, Jarrah, $17(3): 70-4$, 1976. (B.A., 41(10): 103, oct., 1977).

GOULDEN, D.S. Effect of sowing rate and sowing date on lupin seed yield. New Zealand Journal Agriculture. Wellington, $4(2): 181-4,1976$.

GRANATO, I. A adubação verde. São Paulo, Ed. Monteiro Lobą to, 1925. p. 103-4. 
HERBERT, S.J. Growth and grain yield of Lupinus albus at different plant population. New zealand Journal of Agricultural Research, wellington, 20(4): 459-65, 1977.

HERBERT, S.J. Influence of branch removal, plant density and species on pode set and seed yield of lupins. Proceedings Agronomy Society and zealand, Christchurch, 7 : 69$-73,1977$.

HERBERT, S.J. Density studies on lupins. I. Flower development. Annals of Botany, Oxford, $43(1): 55-63,1979$.

HERBERT, S.J. Density studies on Iupins. II. Components of seed yield. Annals of Botany, oxford, $43(1): 65-73$, 1979 .

IGUE, I.; ALCOVER, M.; DERPSCH, R.; PAVAN, M.A. ; MELLA, S.C.; MEDEIRos, G.B. Adubạ̧ão orgānica. Informe da pesquisa, Londrina, 8(59): $1-33,1984$.

IVANOV, I.A. A study of stand densities of white lupin grown for green fodder at high altitudes in the niddle part of Rhodope Mountains. Rastenievud Nauki, 11 (5): 98-107, 1974. Apud Herbage Abstracts, Farnhan Royal, 45(8):271, Aug. 1975 .

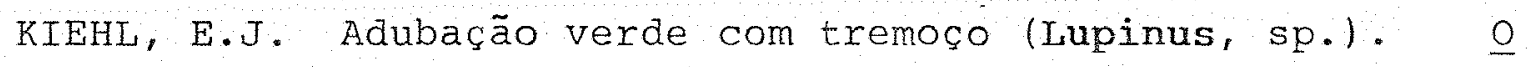
Solo, Piracicaba, 41: 51-63, out. 1949.

LEAL, J.C. Tremoço. In: Leal, J.C. Plantas da lavoura sul Rio-Grandense. Porto Alegre, UFRGS, 1970. p. 260-5.

LEES, P. Lupinos. Agricultura de las Américas, Kansas, 27 (3): 29-59, mar. 1978 . 
LOPES, M.S. Adubação orgānica. Lavoura Arrozeira,

Porto Alegre, 37(348): 20-2, jan./fev. 1984.

MASEFIELD, G.B. Further trials of pearl lupin in England. Experimental Agriculture, London 12 (2): 97-102, 1976.

MCGIBBON, R. \& WILLIAMS, W. Effect of plant and canopy density on seed yield and oil content in white lupin (Lupinus albus). Experimental Agriculture, Iondon, $16(4)$ : $409-14,1980$.

MIYASAKA, S.; CAMARGO, O.A. de; CAVALERI, P.A.; GODOY, I.J. de; WERNER, J.C.; CURI, S.M.; LOMBARDI NETO, F.; MEDINA, J.S., CERVELINI, G. da SILVA \& BULISANI, E.A. Adubação orgānica, adubação verde e rotação de culturas no Estado de São Paulo. Fundação Cargill. Campinas, 183 p. 1983.

MIYASAKA, S. In: Adubação verde no Brasil. Fundação Cargil1. Campinas, 67-82. 1984.

MORA, G., S. Adaptación, producción y utilizaciōn del lupino en Chile. Agro-Sur, Valdivia, $8(1): 43-56,1980$.

MUNTEAN, L. Variation in morphological characteristics and productivity of white lupin as a function of cultural conditions. Agricultura, 28: 205-10. Apud Field Crop Abstracts, Aberystwyth, $28(10)$, oct. 1975.

MUZILLI, O.; VIEIRA, M.J.; PARRA, M.S. Adubação verde. In: Instituto Agronōmico do Paraná. Manual Agropecuário do Paraná. Londrina, IAPAR, 1980. J. 3, p. 77-97. 
MUZILLI, O.; OLIVEIRA, E.L.; GERAGE, A.C.; TORNERO, M.T. Adubação nitrogenada em milho no paraná. III. Influéncia da recuperação do solo com adubação verde de inverno nas respostas à adubação nitrogenada. Pesquisa Agropecuária Brasileira, Brasilia, 18(1): 23-7, jan. 1983.

- TREMOCo na adubação verde. São Paulo, Secretaria Agricola Comércio e Obras públicas, $357-8$ (Boletim, 7). 1925.

PLANCQUAERT, P. Effect of the varieties, seed rates and drill space and irrigation on yield of white lupine. In: CONFERENCIA INTERNACIONAL DEL LUPINO, 2, TOrremolinos, 1982. Resumenes. p. 27.

RAHMAN, M.S. \& GLADSTONES, J.S. Temperature responses of lupin species during germination and flower development. Journal of the Australian Institute of Agricultural Science, Wellington, 39(4): 259-62, 1973 .

RAHMAN, M.S. \& GLADSTONES, J.S. Fffects of temperature and photoperiod on flowering and yield components of lupin genotypes in the field. Australian Journal of Experimental Agriculture and Animal Husbandry, Melbourne, 14 (67): $205-13,1974$.

REEVES, T. Lupins; an all purpose. Crop. Dairyman, Chandler, 27-9, 1976 .

REEVES, T.G.; BOUNDY, K.A.; BROOKE, H.D. Phenological development studies wity Lupinus angustifolius and L. albus in Victoria. Australian Journal of Experimental Agriculture and Animal Husbandry, Melbourne, 17(87): 637$-44,1977$. 
SABADIN, H.C. Adubação verde. Lavoura Arrozeira, Porto Ale gre, $37(354): 19-26$, set./out. 1984 .

SANTOS, H.P. dOS; LHAMBY, J.C.B.; TOMASINI, R.G.A.; BAIER, A.C. Pesquisas desenvolvidas com tremoço (Lupinus spp) em Passo Fundo no periodo de 1980 a 1983 . Passo Fundo, EMBRAPA/CNPT, 1984. 19 p. Documentos, 6.

SILVA, F.C.M. da. Mineralogia e gênese de uma sequéncia de solos no municipio de Bandeirantes-PR. Lavras, 1985.130 p. (Mestrado - Escola Superior de Agricultura de Lavras).

SCHERER, E.E. O tremoco e seu cultivo no estado de santa Ca tarina. Florianópolis, EMPASC (Boletim técnico, 14). 1982. $20 \mathrm{p}$.

TOMASINI, R.g.A. Tremoço na região do sul do Brasil. Lavoura Pecuária, Porto Alegre, 5(20): 21-4, mar. 1982 .

TOMASINI, R.G.A.; LHAMBY, J.C.B.; SANTOS, H.P. dos. O tremoco no Brasil. Passo Fundo, EMBRAPA/CNPT, 1982. $19 \mathrm{p}$. (Documentos, 1).

TREMOÇO: uma leguminosa em três espécies e diversas finalidades. Balde Branco, São Paulo, 20 (252): 24-7, out. 1985.

UFER, M. O Lupino (tremoco) Branco Doce; seu cultivo e seu valor. A Granja, Porto Alegre, 12 (111/112): 81, 1956.

Um que não escolhe lugar. Dirigente Rural, são paulo, $2: 3$, dez. 1962 . 
WALTON, G.H. Trials indicate best lupin seedling rates. Journal of Agriculture Western Australia, Janah Rd, 19 (2) : 59,1978 .

WALTON, G.H. Lupins; better practices for higher production. Journal of Agriculture Western Australia, Janah Rd, 77-80. 1982 .

WIGGERS, M.S.; JOSINO, I.; SANTOS, H.P. dOS. COMp. Bibliografia internacional de Tremoço; Lupinus albus L., Lupinus luteus L.; Lupinus angustifolius L. Brasilia, EMBRA$\mathrm{PA} / \mathrm{DID}, 1983.359 \mathrm{p}$.

WITHERS, N.J.; BACKER, C.J.; LYNCH, T.J. Some effects of date, rate and method of sowing on lupin seed yield. Proceedings Agronomy Society New Zealand, Christchurch, 4. $4-8,1974$.

WITHERS, N.J. \& EDGE, E.A. Effects of water stress on Lupinus albus. IV. Response to high temperature and adequate and restricted water. New Zealand Journal of Agricultural Research, Wellington, 22(4): 571-75, 1979. 